الجمعية المصرية للقر اعة والمعرفة عضو الجمعية الدولية للمعرفة اLل

أثر استجابة المتسوق السعودي لعروض تنشيط المبيعات في الصيدلية على قرار الشراء

$$
\begin{aligned}
& \text { (دراسة ميدانية بمدينة جدة) } \\
& \text { إعداد رفعه تركي إسماعيل مله } \\
& \text { أستاذ مساعد بمسار السكن وإدارة المؤسسات - قسم الإسكان } \\
& \text { كلية الاقتصاد المنزلي - جامعة الملك عبد العزيز }
\end{aligned}
$$


الجمعية المصرية للقراءة والمعرفة عضو الجمعية الدولية للمعرفة ILA 


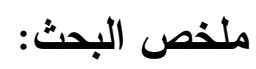

تكمن مشكلة البحث في أن عروض تتشيط المبيعات قد تخلق لدى المتسوق

احتياجات غير حقيقية مما يجعل استجابته لهذه العروض سلبية تؤدي إلى زيادة الاستهلاك والانفاق وذللك لعدم وعيه بكيفية الاستجابة لعروض تتشيط المبيعات والتعامل معها وبالتالي يكون قرار الشراء غير رشيد؛ لذا قامت الباحثة بهذا البحث بهدف التعرف على العلاقة بين الوعي للاستجابة لعروض تتشيط المبيعات في الصيدلية ورشد قرار الشراء بالإضافة إلى الكثف عن الفروق في الوعي للاستجابة لعروض تتشيط المبيعات في الصيدلية تبعاً لخصائص المتسوق، والكثف عن الفروق في رشد قرار الثراء تبعاً لخصائص المتسوق أيضاً، وقد اعتمد البحث المنهج الوصفي التحليلي، وتم استنفاء

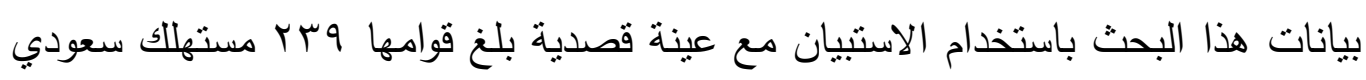

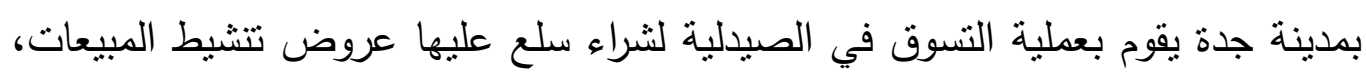

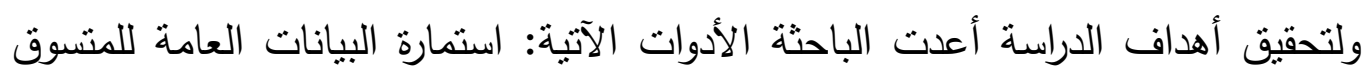
وعروض تتشيط المبيعات في الصيدلية، واستبيان الاستجابة لعروض تتشيط المبيعات في الادواني

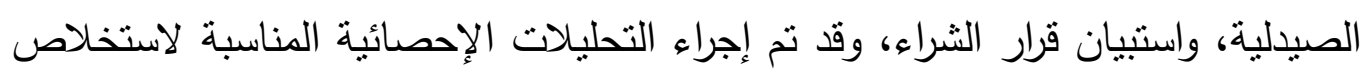
النتائج والتحقق من مدى صحة الفروض، وكانت أهم النتائج أن هنالك علاقة ارتباطية طردية بين الوعي للاستجابة لعروض نتشيط المبيعات في الصيدلية ورشد قرار الثراء، كما وجد أن هناك فروق ذات دلالة إحصائية بين متوسط درجات أفراد العينة في وعيهم للاستجابة لعروض تتشيط المبيعات في الصيدلية تبعاً لمتغيرات الدراسة، ووجد أيضاً فروق ذات دلالة إحصائية بين منوسط درجات أفراد العينة في رشد قرار الثراء تبعاً

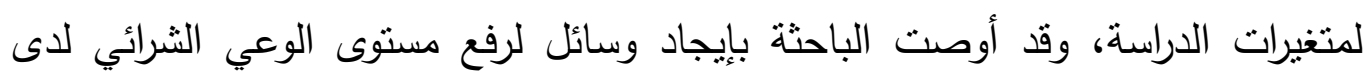
المتسوق وتوجيهه باتخاذ قرار شراء السلع من الصيدليات على أسس سليمة وفقاً لاحتياجات حقيقية، وأوصت أيضاً بتصميح وإعداد وتتفيذ برامج لتتمية الوعي الاستهلاكي والانفاقي لدى المتسوق في ظل هذه العروض، وإكساب المتسوق كفاءة ومهارات وخبرات 


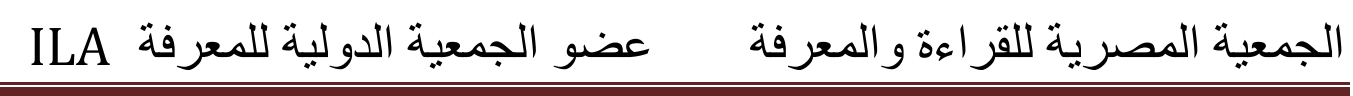

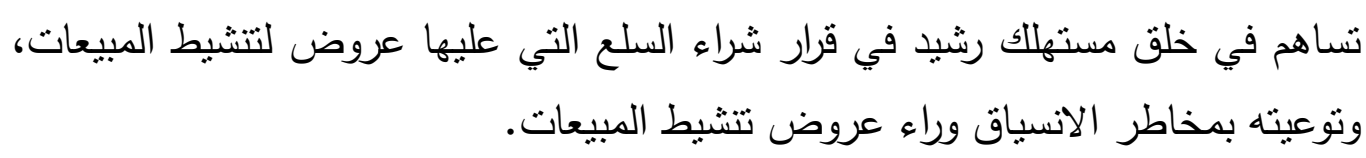

\section{Summary Research:}

The research problem lies in that sales promotion offers may

drive shopper for unreal needs, which makes him negatively respond to these offers, leading to increasing his consumption and spending for his lack of awareness of how to respond to sales promotion offers and deal with them and take the rational decision of purchase. Therefore, the researcher aimed in this study to find out the relationship between awareness of the response to sales promotion offers in the pharmacy and the rational purchase decision, in addition to identify differences in awareness to respond to sales promotion in a pharmacy according to the shopper's characteristics, and to identify differences in the rationality of the purchase decision according to the shopper's characteristics also. The research adopted the analytical descriptive method, and the information of this research was fulfilled by using a questionnaire with a purposive sample consisted of 239 Saudi consumers in Jeddah who were shopping items with sales promotion offers in a pharmacy. To achieve the study's objectives, the researcher prepared the following tools: Shopper's general information form, sales promotion offer in a pharmacy, response questionnaire for sales promotion in a pharmacy, and purchase decision questionnaire. The appropriate statistical analyses were performed to derive the results and verify the validity of the hypotheses. The most important results were that: there was a positive correlation between the response awareness of sales promotion offer in the pharmacy and rational purchasing decision. There were statistically significant differences between the mean scores of the respondents in their response awareness to sales promotion offers in the pharmacy according to the study variables. 
There were also statistically significant differences between the mean scores of the respondents in their rational purchasing decision according to the study variables. The researcher recommended finding ways to increase shopper's purchasing awareness and directing him to take the decision to buy the goods from the pharmacies on a sound basis according to his real needs. It is also recommended designing, propagating and implementing programs to develop shopper's consumption and spending awareness under these offers, providing him with skills and experiences that contribute to create a rational consumer in his decision to purchase items with sales promotion offers, and to aware him of the risks of driving behind sales promotion offers.

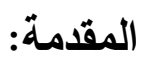

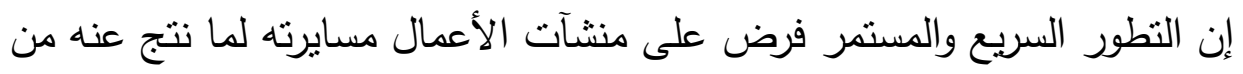

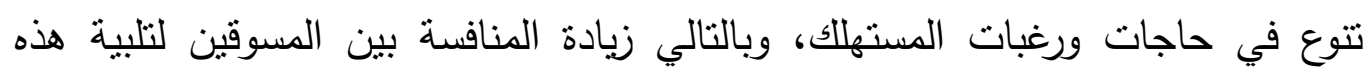
الحاجات والرغبات وإرضاء المستهلاك، كما فرض هذا التطور تزايدًا في استخدام وسائل

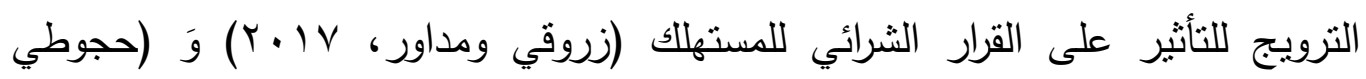

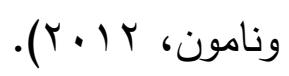

وقد لوحظ التحول السائد عالمياً من التركيز على وسائل الترويج التقليدية، كالبيع

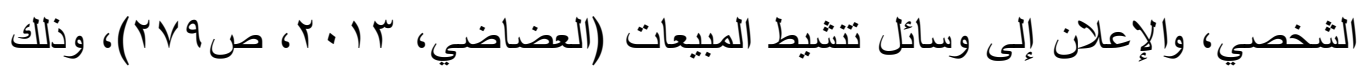

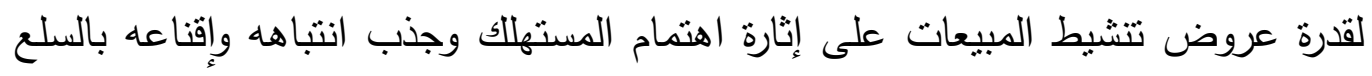
للحصول عليها وخلق الحاجة والطلب لها لتحقيق الاستجابة المرغوب في تحقيقها للمستنهالك.

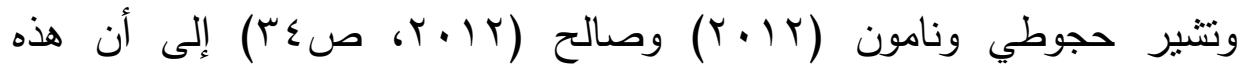

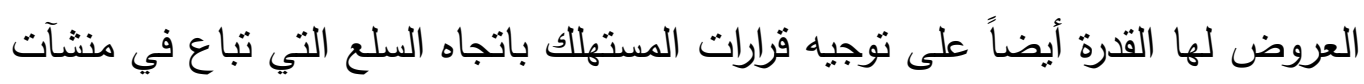

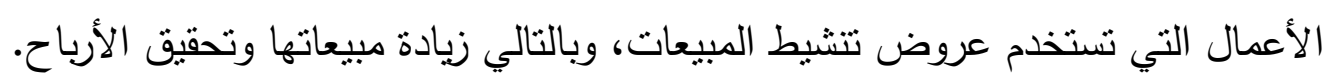


إلا أن أدوات تتشيط المبيعات قد تؤثر سلباً على المستهلك وسلوكه الاستهلاكي

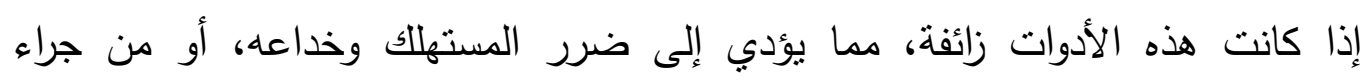

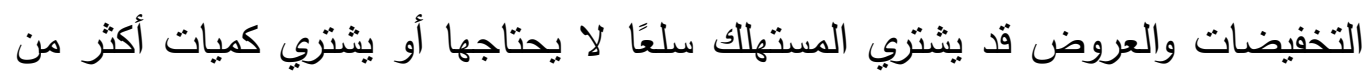

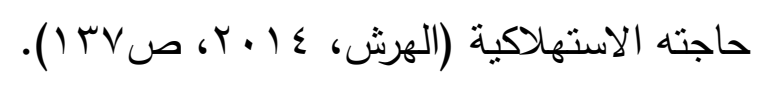

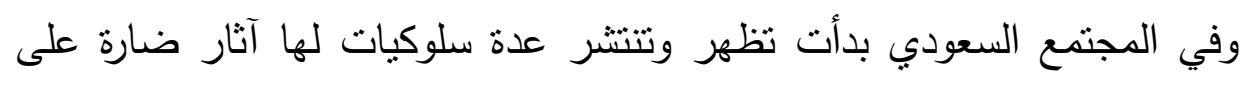

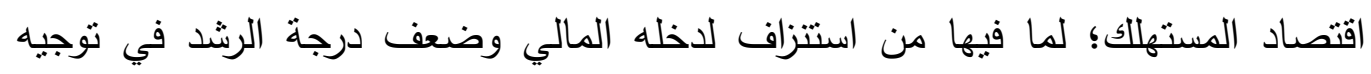

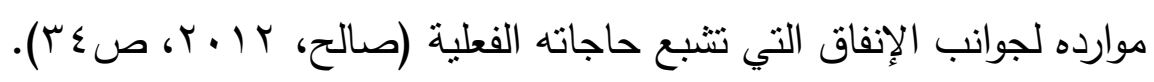

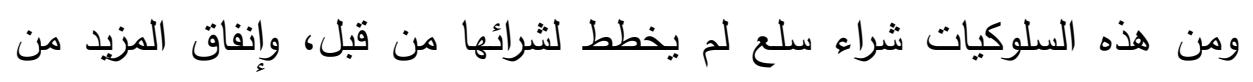

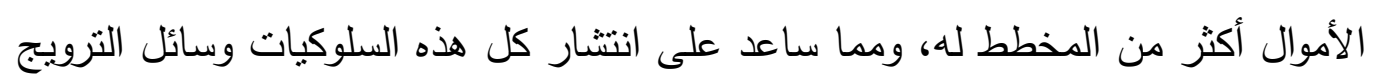

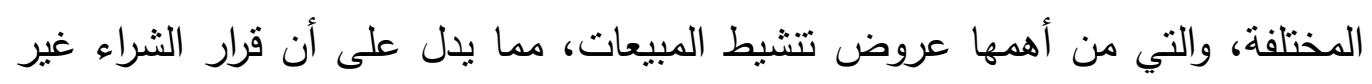

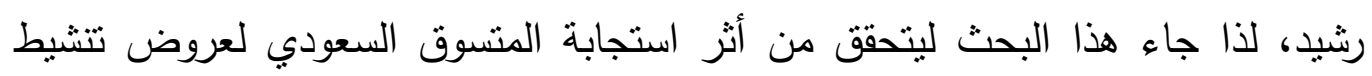

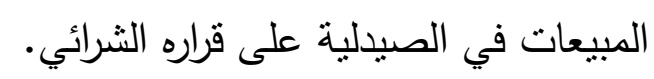

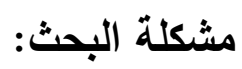

إن التتبؤ بسلوك المستهلك وكيفية اتخاذ قرار شراء السلع من المواضيع المعقدة

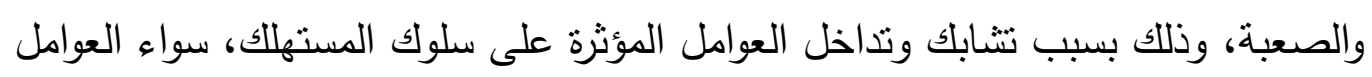

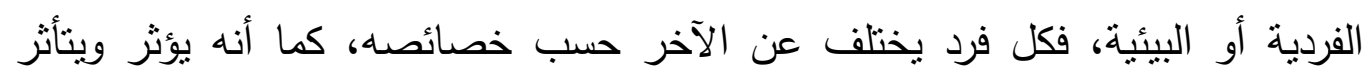

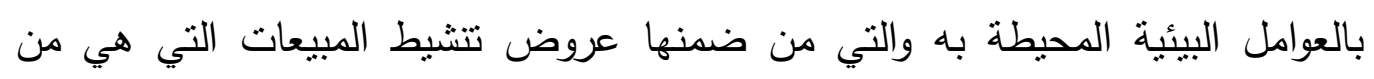

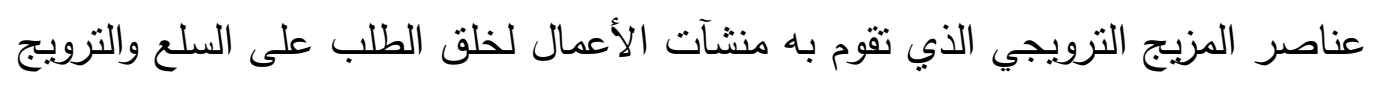

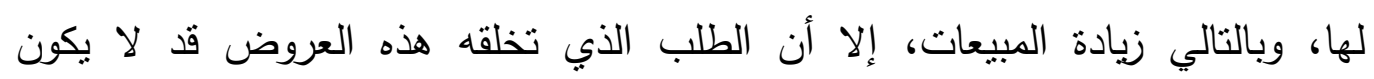

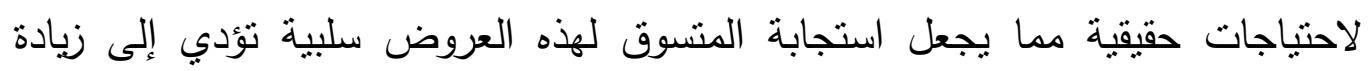

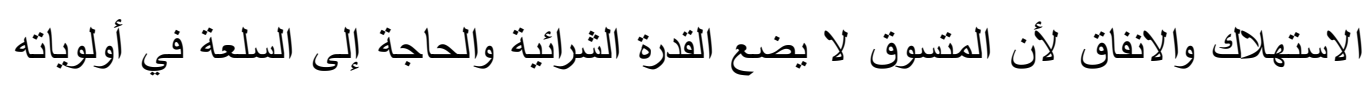

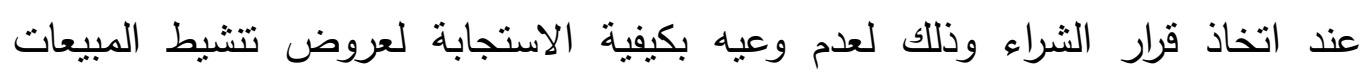

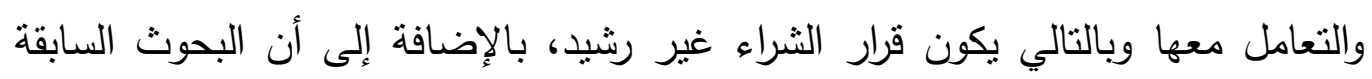

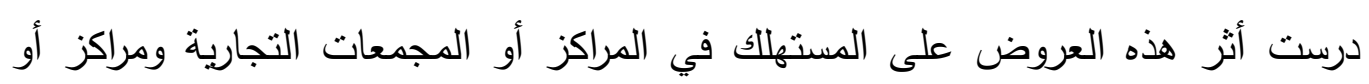


متاجر خدمة النفس والتجزئة، ولكن قلة من هذه البحوث التي درست أثز عناصر المزيج الترويجي وبخاصة عروض تتشيط المبيعات في الصيدلية على القرار الثرائي للمستهلك، كما أن هذه البحوث لم تشمل كل السلع التي تباع في الصيدليات.

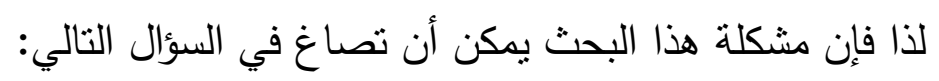

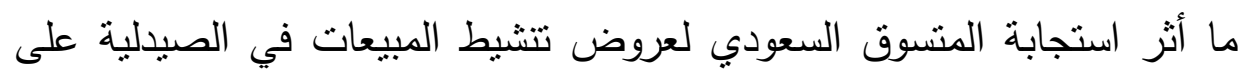

$$
\text { قرار الثراء؟ }
$$

ينلخص هدف البحث الأساسي في التعرف على أثز استجابة المتسوق السعودي لعروض تتشيط المبيعات في الصبدلية على قرار الثراء، وتتبثق منه الأهداف الفرعية الآثية:

1- التعرف على الخصائص الاجتماعية والثقافية والاقتصادية للمتسوق السعودي الذي يشتري السلع من الصيدلية في وقت عروض تتشيط المبيعات. r- التعرف على عروض تنشيط المبيعات في الصيدلية التي تؤثر على قرار شراء المتسوق السعودي. ب- التعرف على السلع التي يشتريها المتسوق السعودي من الصيدلية في وقت عروض تكن تشتيط المبيعات. ع- الكثف عن العلاقة بين الوعي للاستجابة لعروض تتشيط المبيعات في الصيدلية ورشد قرار الشراء. 0- الكثف عن الفروق في الوعي للاستجابة لعروض تتشيط المبيعات في الصيدلية تبعاً لخصائص المتسوق. צ- الكثف عن الفروق في رشد قرار الثراء تبعاً لخصائص المتسوق. V- التعرف على نسبة مشاركة العوامل الاجتماعية والثقافية والافتصادية للمتسوق المؤثرة على رشد قرار الثراء حسب أهميتها. 
1- التعرف على الأوزان النسبية لأولوية الاستجابة لعروض تتشيط المبيعات في الصيدلية

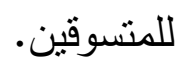

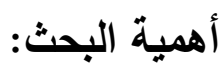

على المستوى الأكاديمي يعد هذا البحث - على حد علم الباحثة - من أوائل

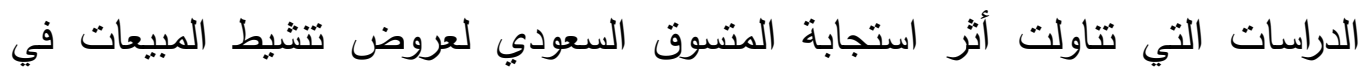

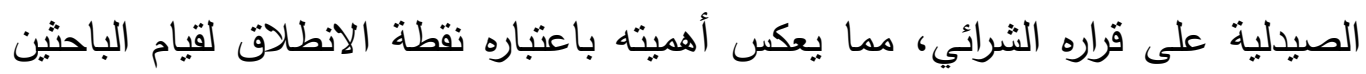

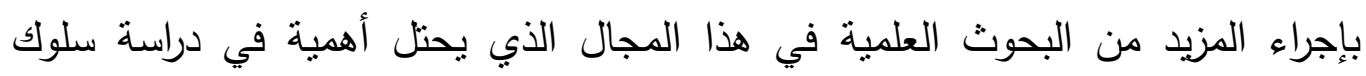

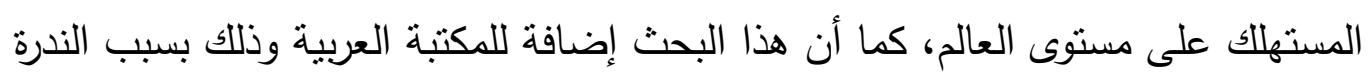
الثنديدة في البحوث النطبيقية على النسوق من الصيدليات وتحديداً بالمملكة العربية

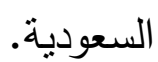

وعلى المستوى التطبيقي يلفت هذا البحث نظر المستهلكين إلى الطرق التي يجب

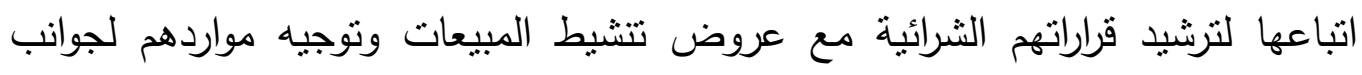

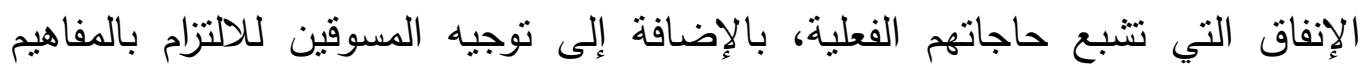

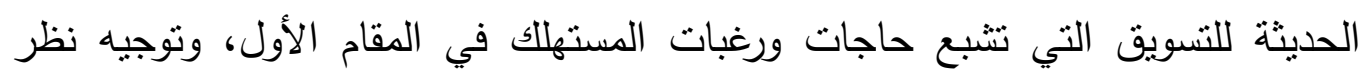

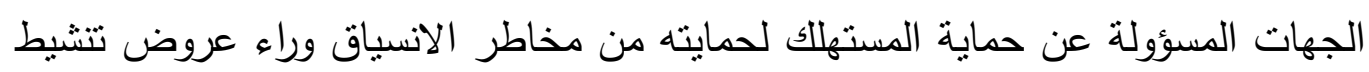
المبيعات خاصة إذا كانت هذه العروض زائفة.

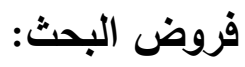
1- توجد علاقة ارتباطية بين الوعي للاستجابة لعروض تتنيط المبيعات في الصيدلية ورشد قرار الثراء. ץ- توجد فروق ذات دلالة إحصائية بين متوسط درجات أفراد العينة في وعيهم للاستجابة

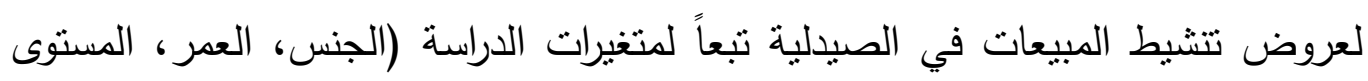
التعليمي، المهنة، دخل المتسوق الثهري). 


\section{الجمعية المصرية للقراعة والمعرفة عضو الجمعية الدولية للمعرفة ILA}

r- توجد فروق ذات دلالة إحصائية بين متوسط درجات أفراد العينة في رشد قرار الثراء

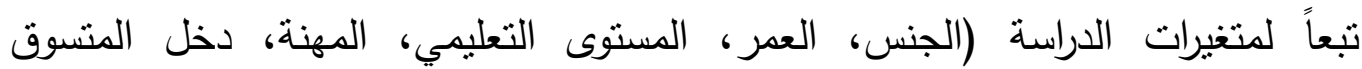

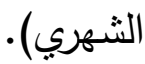
ع - تختلف نسبة مشاركة العوامل المؤثرة على رشد قرار الثراء. ه- تختلف الأوزان النسبية لأولوبة الاستجابة لعروض تتشبط المبيعات في الصبدلية لأفراد عينة البحث. مصطلحات البحث الإجرائية: 1- 2 - استجابة المتسوق:

هي الاستجابة السلوكية للمستهلك التي تحفزها عروض تتشيط المبيعات منل تسريع الثراء، وزيادة الكمية المشتراة، وتجربة منتج جديد، والتحول لماركة أخرى، وزيادة الانفاق.

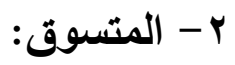

هو المستهلك الفرد والنهائي الذي يشتري السلعة لاستخدامها الخاص أو العائلي استخدامًا نهائيًا.

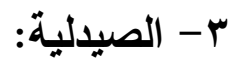
هي منشأة مستقلة لبيع الأدوية والمستحضرات الطبية ومستحضرات وأدوات وأجهزة العناية

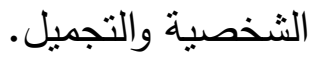
ع - عروض تنشيط المبيعات: هي أنشطة تسويقية تحفز المستهلك على شراء السلع منل خصومات الأسعار، وشراء سلعة والثانية مجانًا، والعينات المجانية، والهدايا وغيرها من العروض.

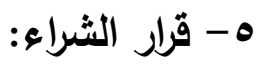

قرار الثراء يتكون من عدة مراحل هي الثعور بالحاجة، والبحث عن المعلومات، وتقييم البدائل، وقرار الثراء، وسلوك ما بعد الثراء.

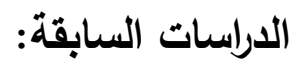
تم عرض الدراسات السابقة تبعاً لتتابعها الزمني من الأقدم إلى الأحدث. 


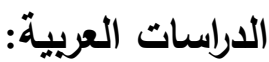

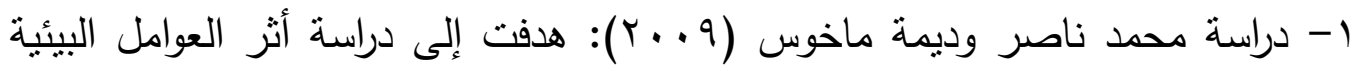

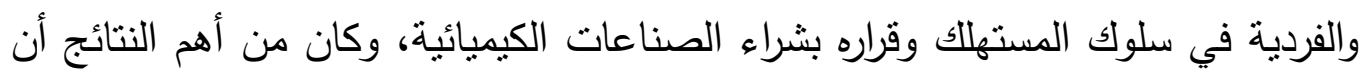

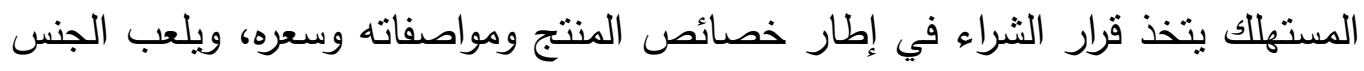

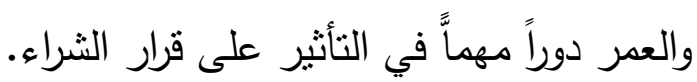

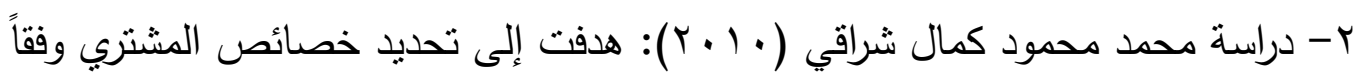

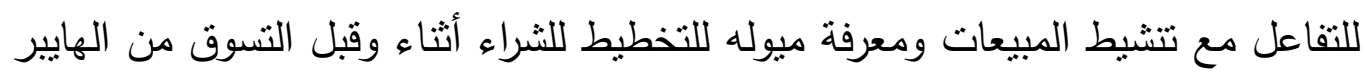
ماركت، وكان من أهم النتائج أن هناك علاقة موجبة بين تنشيط المبيعات والتخطيط

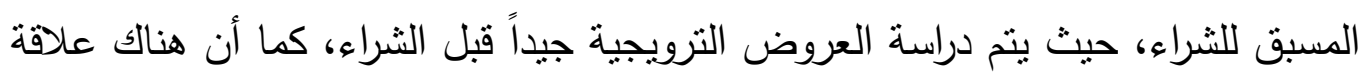
ارتباطية موجبة بين تتشيط المبيعات وتوقيت وتكرار الشراء، حيث وجد إن ؟^\% يفضلون التواجد في فترات العروض والتعامل مع أساليب التتشيط، وكانت تخفيضات التبات الأسعار

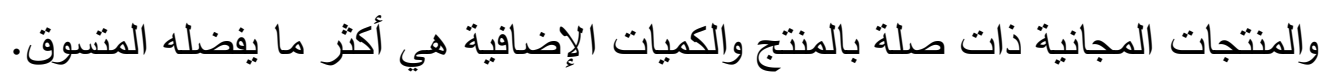

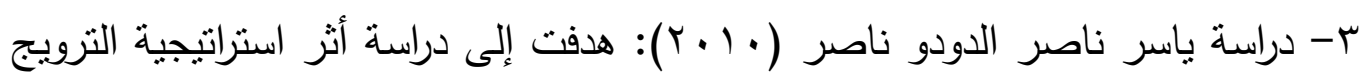

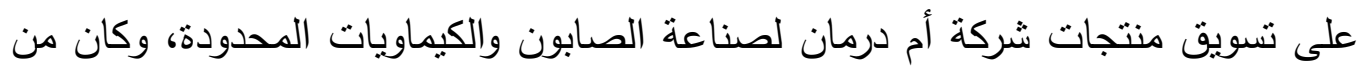

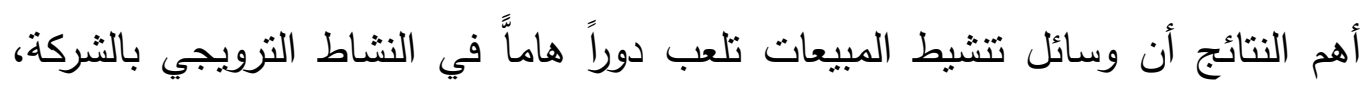
كالمعارض والمسابقات والهدايا.

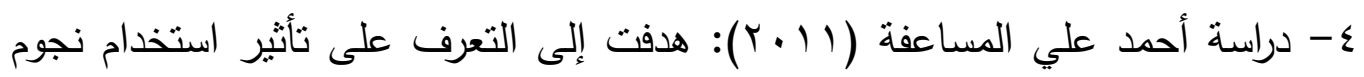

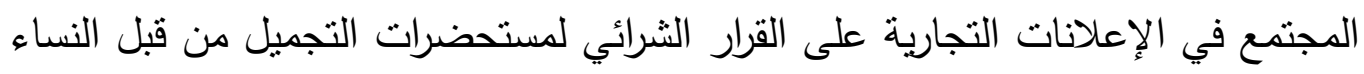

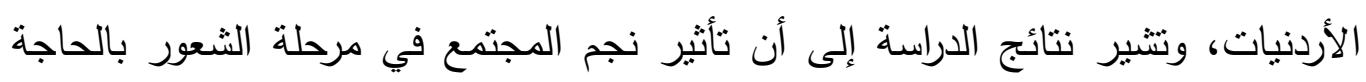

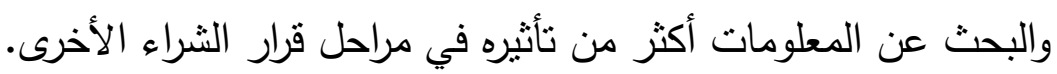

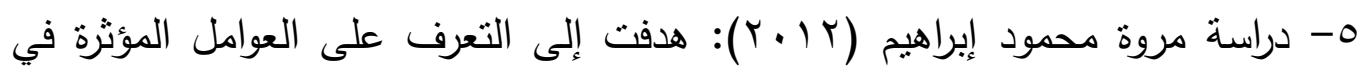

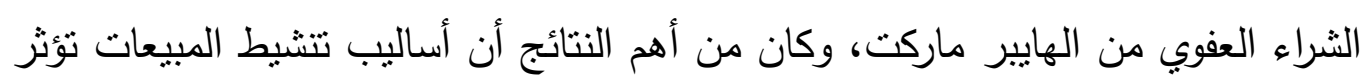

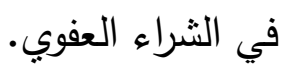




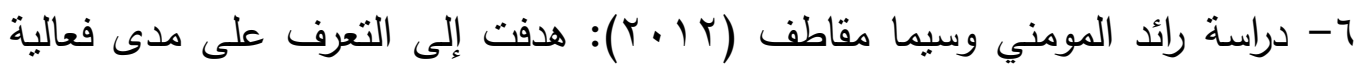

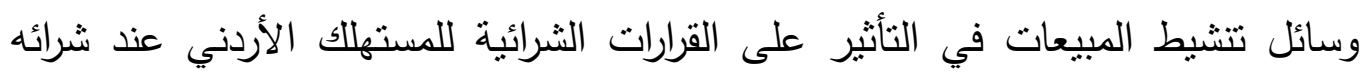

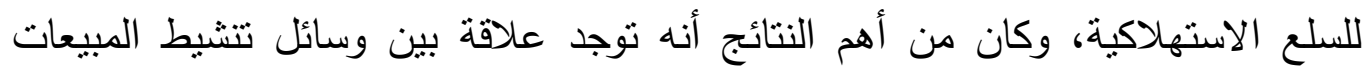

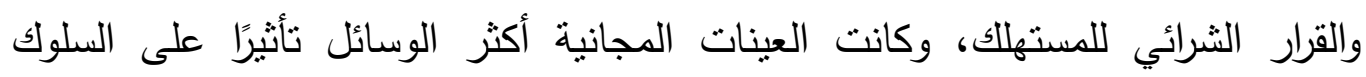
الثرائي.

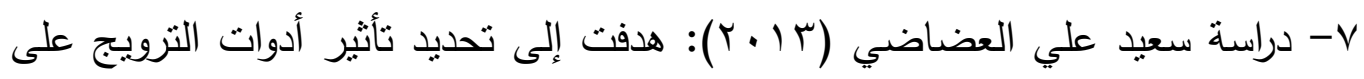

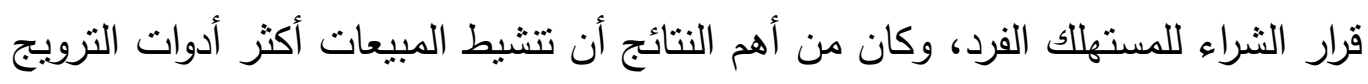

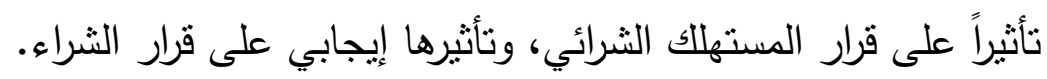

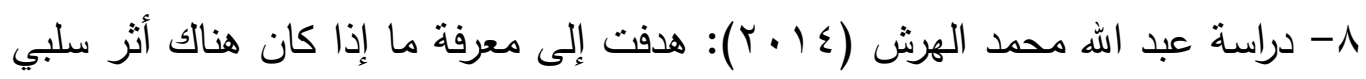

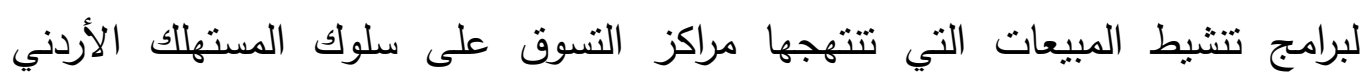

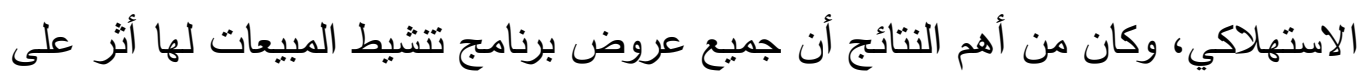

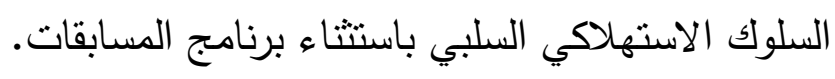

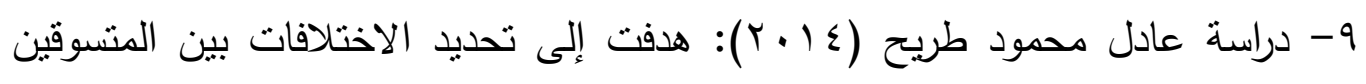

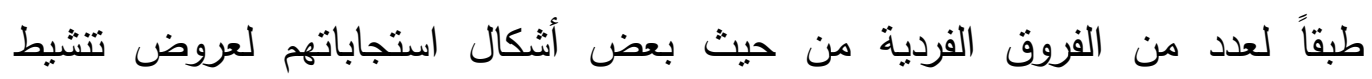

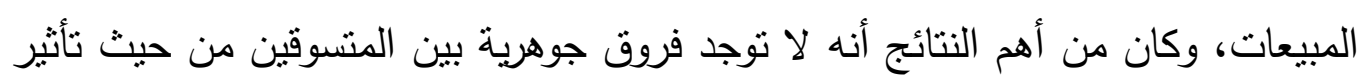

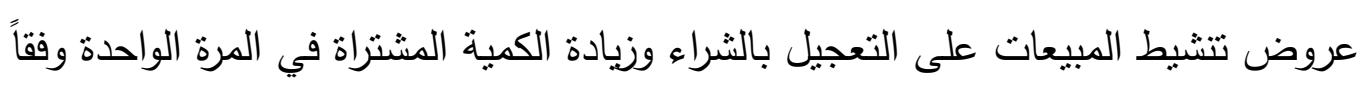
للفروق الفردية بينهم من حيث العمر والحالة الاجتماعية ومستوى التأهيل التعليمي.

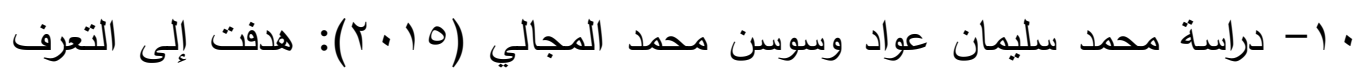

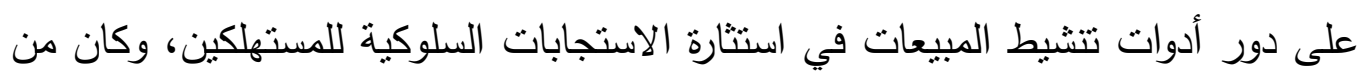

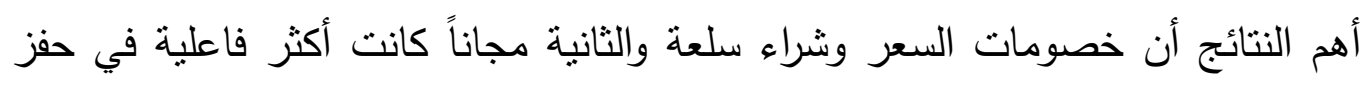

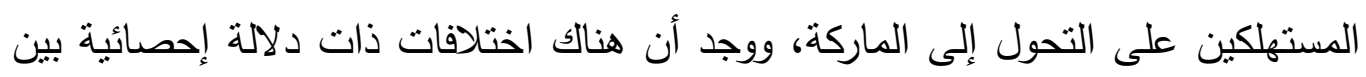

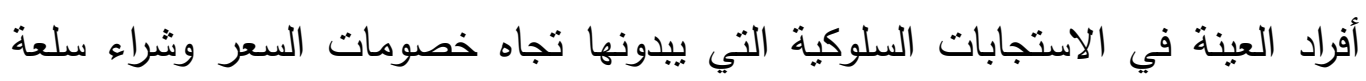

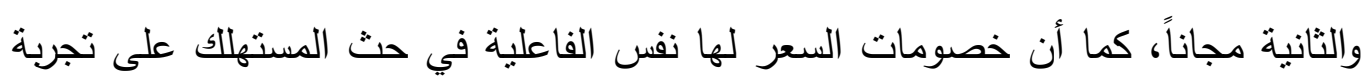

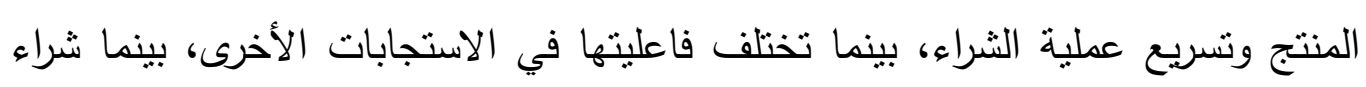




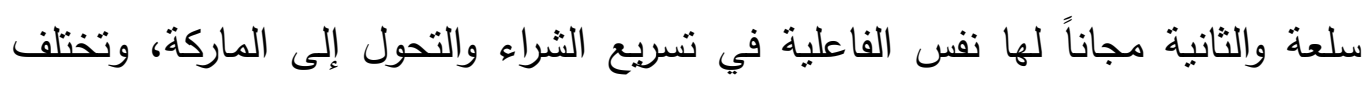
فاعليتها في الاستجابات الأخرى.

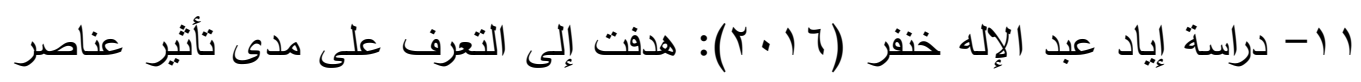

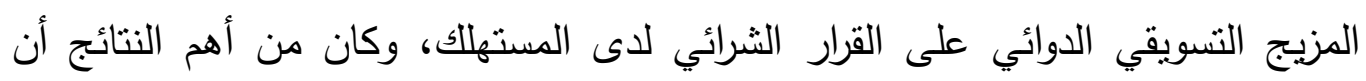

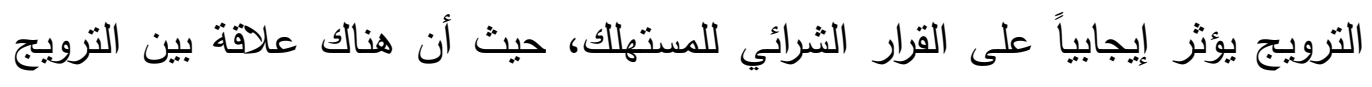
وقرار شراء المرضى للأدوية.

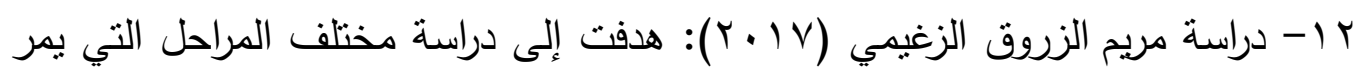

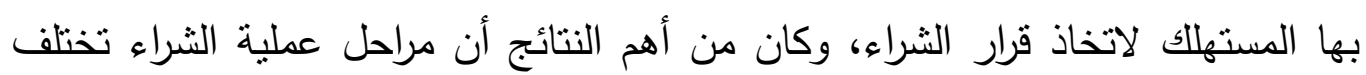

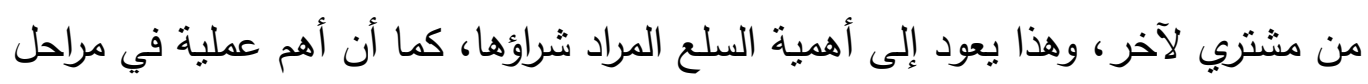

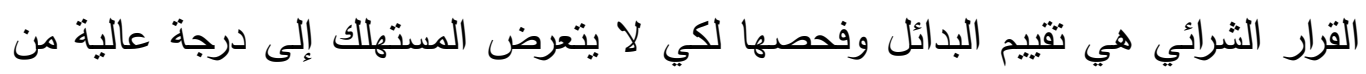
المخاطرة.

\section{الاراسات الأجنبية:}

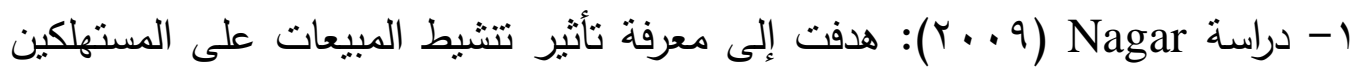

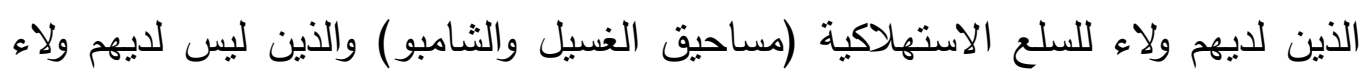

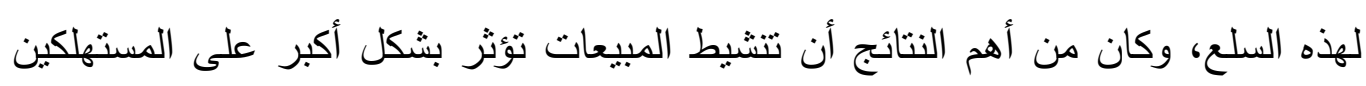

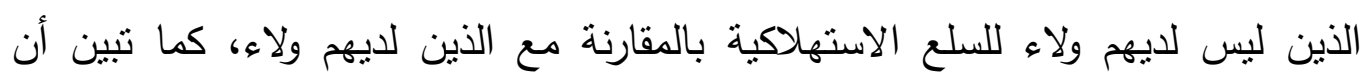

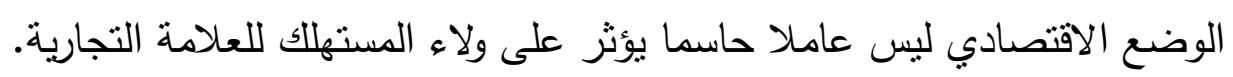

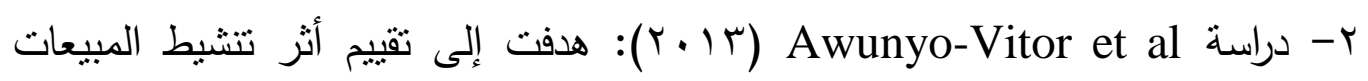
لشركة صابون على سلوك المستهلكين الثباب في مدارس الثانوية العليا في غانا، وكان الثران

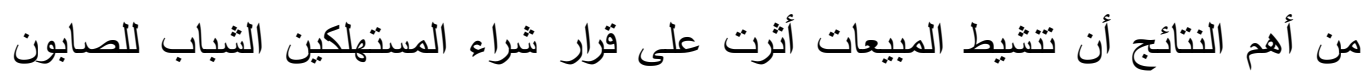
لاستخدامه في المدارس.

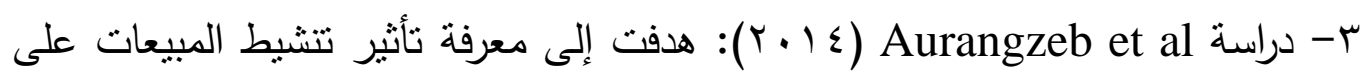
السلوك الثرائي للمستهلك، وكان من أهم النتائج أن شراء سلعة والثانية مجاناً تؤثز بشكل

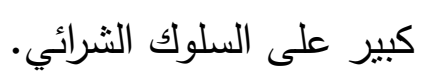




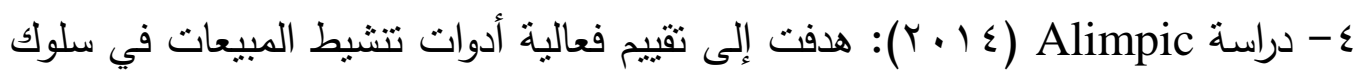

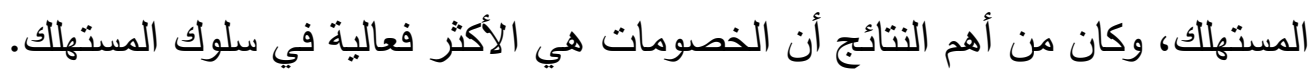
ه- دراسة Obeid (ع ( ب): هدفت إلى تقييم فعالية أدوات تتشيط المبيعات في استثارة

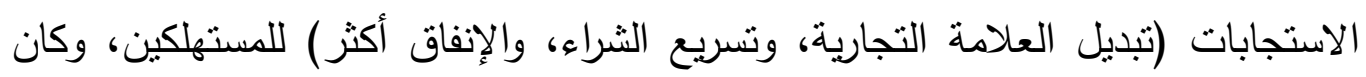

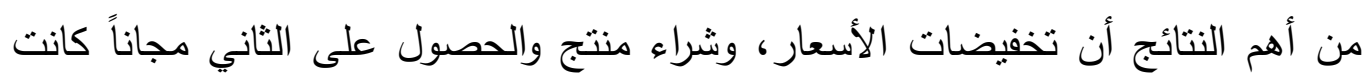

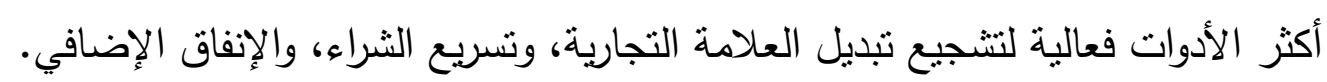

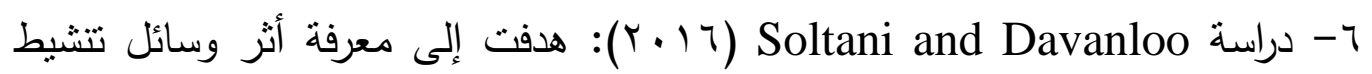

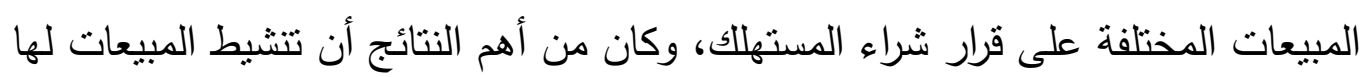

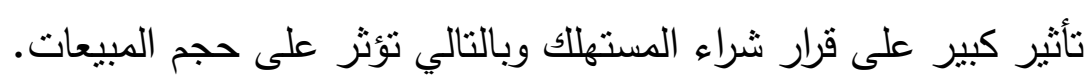

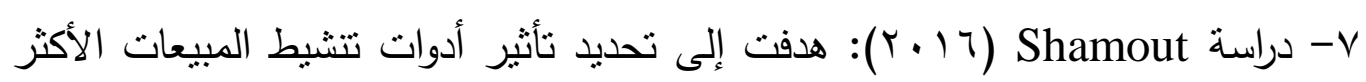

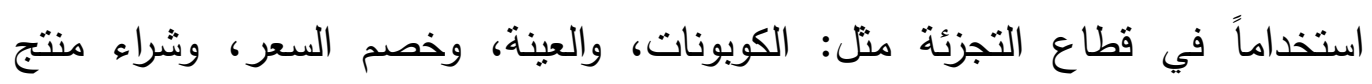

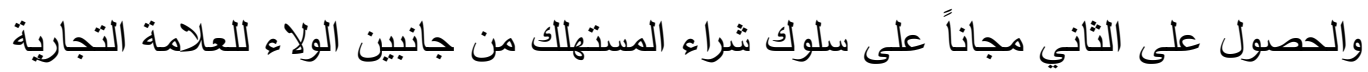

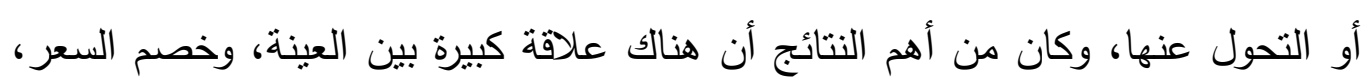

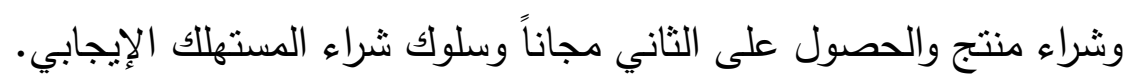
التعقيب على الدراسات السابقة: 1- تتفق معظم الدراسات السابقة على أن عروض تنثيط المبيعات تؤثر على سلوك المستهلك الاستهلاكي وقراره الثرائي.

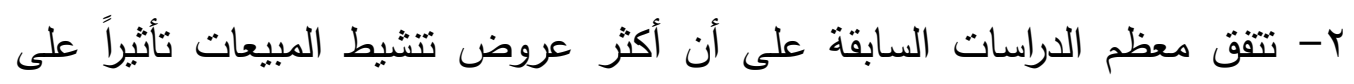
سلوك المستهلك الاستهلاكي وقراره الثرائي هي خصومات الأسعار ، وشراء سلعة والثنانية

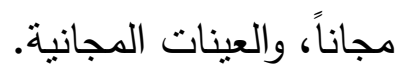

r- تتفق معظم الدراسات السابقة على أن أكثر استجابات المستهلكين لعروض تتشيط

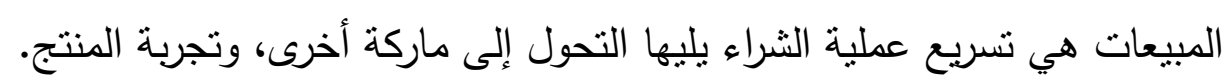

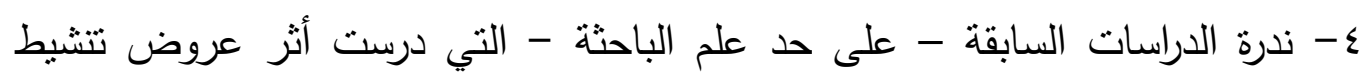
المبيعات في الصيدلية على القرار الثرائي للمستهلك، حيث أن الن معظم الدراسات السابقة 


\section{الجمعية المصرية للقراعة والمعرفة عضو الجمعية الدولية للمعرفة ILA}

درست أثز هذه العروض على المستهلك في المراكز أو الدمعات التجارية ومراكز أو مثاجر خدمة النفس والتجزئة. 0- معظم الدراسات السابقة لم تثمل كل السلع التي تباع في الصيدليات.

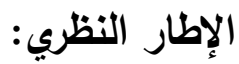
المزيج الترويجي من أهم الوسائل المؤثرة على قرار الثراء لدى المستهلك، ويتكون

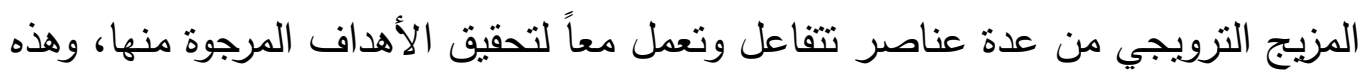
العناصر هي: الإعلان، والبيع الثخصي، والعلاقات العامة، وتتشيط المبيعات (الهرش،

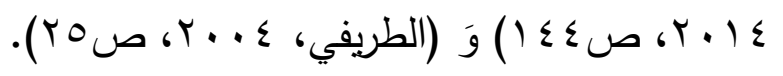

وستركز الباحثة هنا على تتشيط المبيعات لعلاقتها بموضوع البحث.

تنثيط المبيعات

تعريف تنشيط المبيعات:

تعرف الجمعية الأمريكية للتسويق تتشيط المبيعات بأنه أسلوب يتكون من أنشطة

تسويقية غير الإعلان والبيع الثخصي أو النشر الدعائي، والتي تستميل السلوك الثرائي

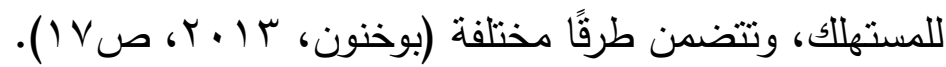

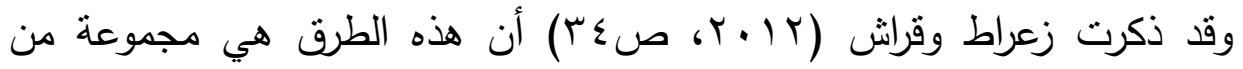
الأدوات والثنتيات الموجهة لتحفيز الطلب في الأجل القصبر والمصمدة لحث المستهلكين على الثراء وتحقيق قيمة مضافة. وتثبر قلال (§ ا.ب، ص اء) إلى أن البعض بستخدم مصطلح ترقية المبيعات أو ترويج المبيعات بدلاً من تتشيط المبيعات. أهداف تنثيط المبيعات المتعلقة بالمستهلك: 1- المحافظة على المستهلكين الحاليين والمحتملين. r- زيادة الاستهالك والطلب على المنتجات الحالية. ب- نتجيع المستهلك على تجربة المنتج، سواء كان جديدًا أو معدلاً. ع- حث المستهلك على الثراء بكميات كبيرة. 
ه- إقناع المستهلكين وتتجيعهم على الشراء خاصة المترددين في اتخاذ قرار الشراء. 7- تشجيع المستهلك الحالي على تكثيف استهلاك السلعة باستخدام الأحجام الكبيرة أو

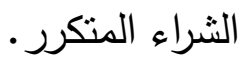
V - Vتجيع المستهلك على الثراء في غير مواسم الاستهلاك. 1- تعزيز ولاء المستهلكين للعلامة التجارية. 9- تفعيل وتعزيز عناصر المزبج التزويجي الأخرى.

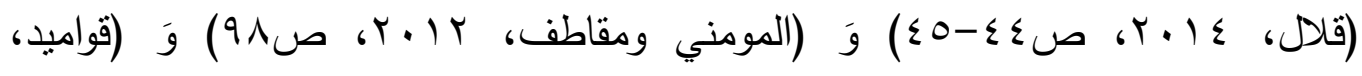

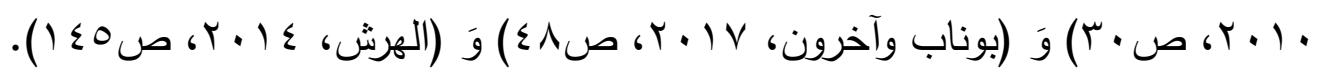
عروض تنشيط المبيعات:

تختلف أدوات تتشيط المبيعات باختلاف الأهداف التسويقية، والمستهلكين

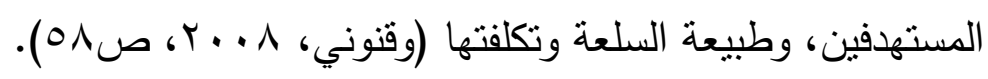

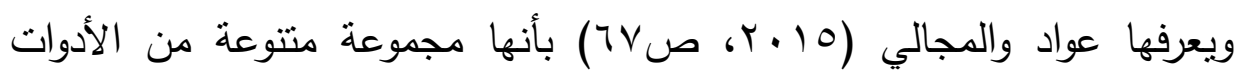
قصيرة الأجل والمصممة لحفز المستهلك على الاستجابة بطريقة معينة، وقد صنفها إلى أدوات سلبية أو خاملة تتطلب من المستهلك بحثاً محدوداً على مكان التسوق، وأدوات إيجابية أو نشطة تتطلب من المستهلك بحثاً نشطًا عن العروض الترويجية.

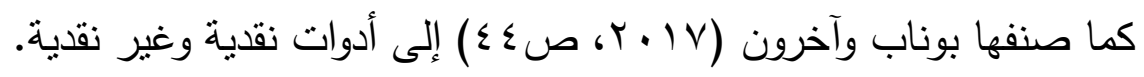

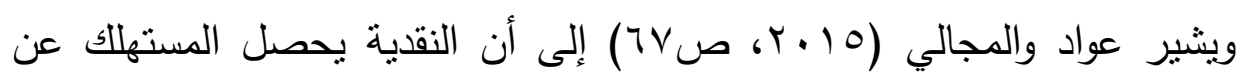
طريقها على السلعة بسعر أقل، بينما غير النقدية تعمل على زيادة القيمة التي يحصل عليها المستهلك مقابل النقود التي يدفعها. وأهم هذه العروض الموجهة للمستهلك الآتي: ا- خصومات الأسعار: وهنا يتم خصم مبلغ معين من الثمن الأساسي إذا تم الثراء خلال فترة محددة، وقد يأخذ الخصم شكلاً آخر ، كأن يتم بيع قطعتين بثمن قطعة واحدة

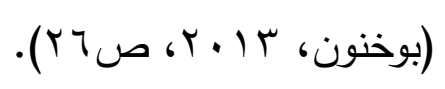




\section{ILA الجمعية المصرية للقراءة والمعرفة عضو الجمعية الدولية للمعرفة}

وقد ذكر عواد والمجالي (10 ب.، صVIT) أن هذه الأداة أكثر فاعلية في تسريع عملية الثراء وتجربة منتج جديد.

r- شراء سلعة والثانية مجاناً: نستخدم عادة كحافز لنشراء مشتريات غير مخطط لها؛ كما

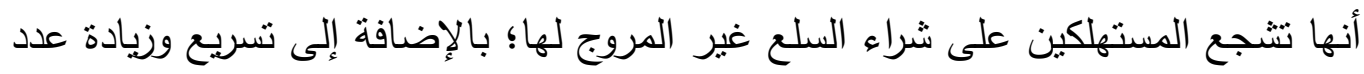

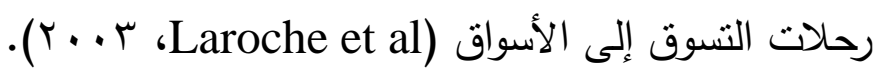

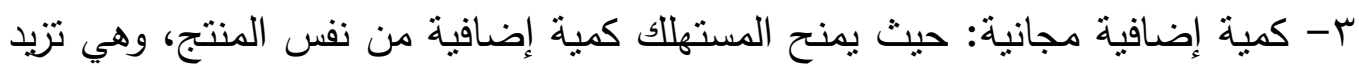
من فرصة تجرية المنتج والتحول إلى الماركة. ع- الهدايا: وهي كحافز لشراء منتج جديد، وتؤدي فعلياً للولاء للماركة.

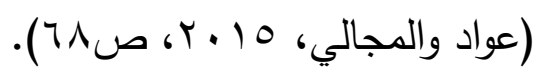

0- النشرات التوضيحية: وهي المنشورات التي يعدها المنتج لتوزيعها على المستهلكين

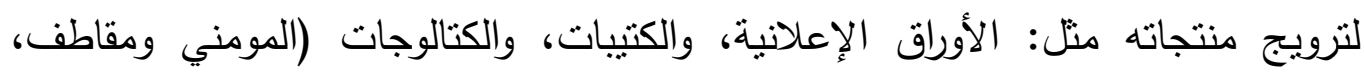

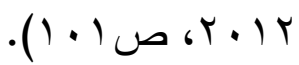
צ- العينات المجانية: وهي وحدة من السلع نوزع مجاناً للتعريف بالسلعة.

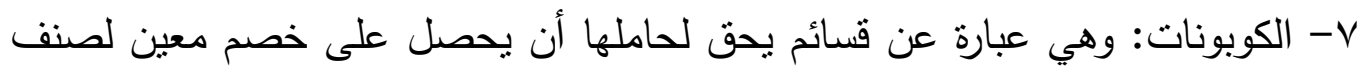

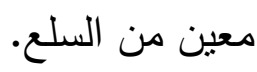
ᄉ- مواد وقطع العرض والإعلان في مواقع الثراء منل: الملصقات، والمواد الإعلامية

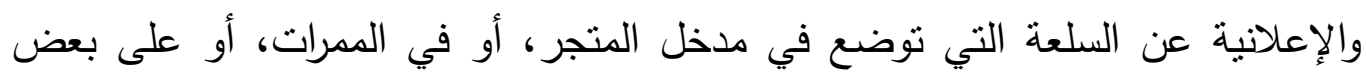
المناضد، أو نوافذ العرض وغيرها. 9- المسابقات: من خلال منح جوائز عينية أو نقدية.

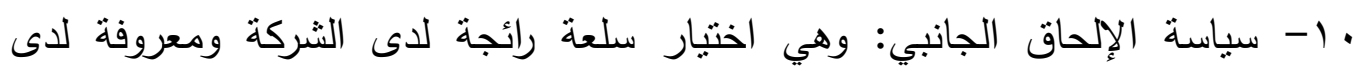

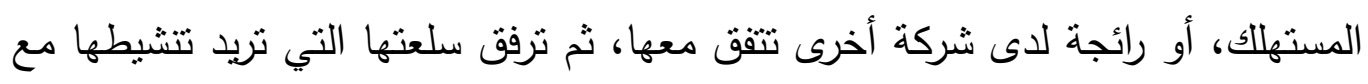

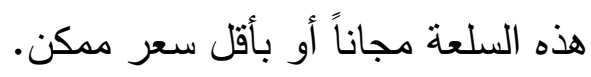

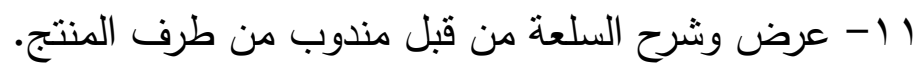


r ا - استرداد مبلغ معين من قيمة السلعة إذا اثترى كمية معينة منها خلال فترة معينة، ويقدم للمتجر أو المنتج ما يثبت ذللك.

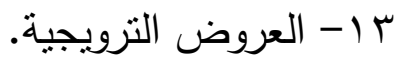

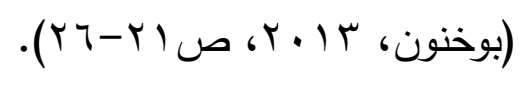

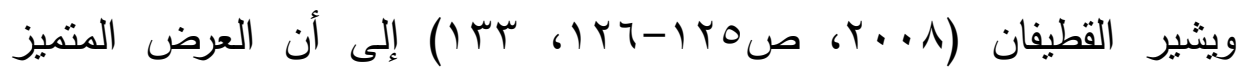

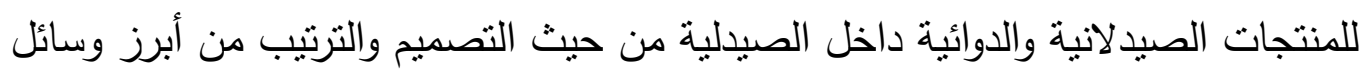

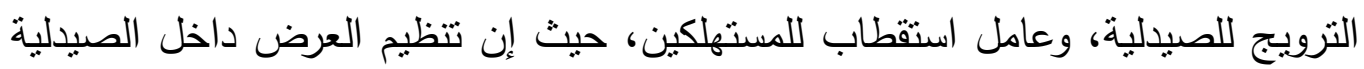

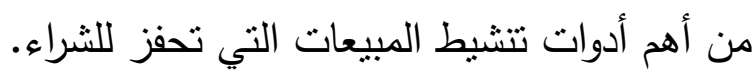

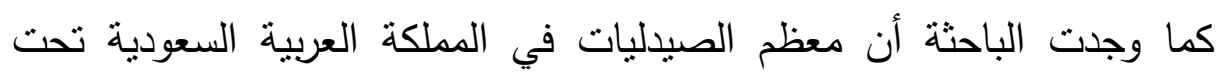

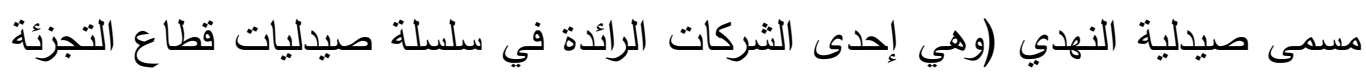

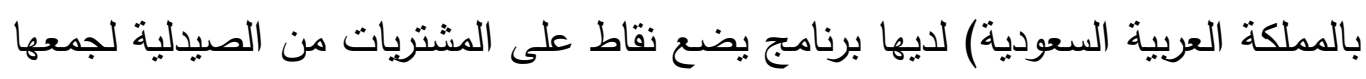

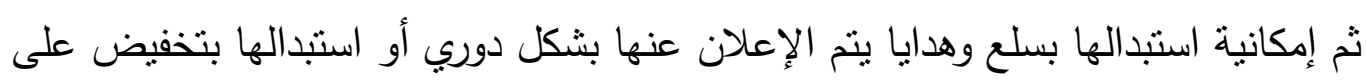
المشتريات (الموقع الرسمي لثركة النهابي). الاستجابة لعروض تنثيط المبيعات:

الاستجابة هي أحد عناصر نظام الاتصالات التسويقية، وهي القبول أو الرفض التضات

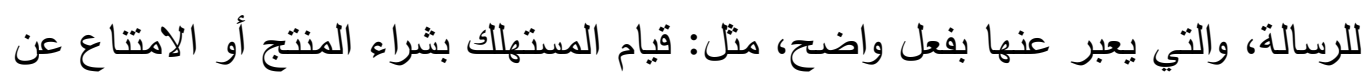

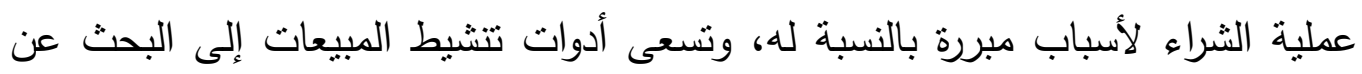

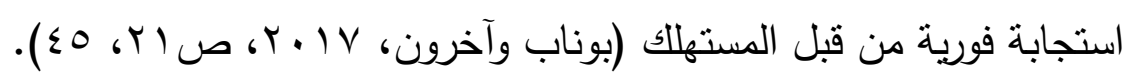

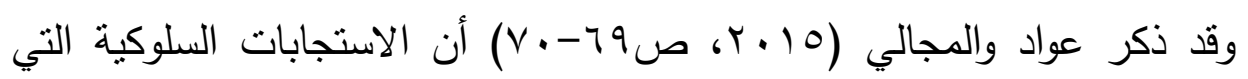

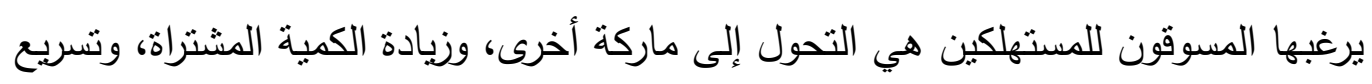

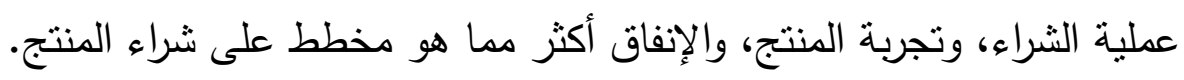

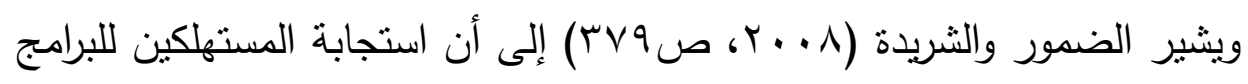
والمحفزات النسويقية نختلف حسب طبيعة المشتري وخصائصده ونوع القرار الثرائي.

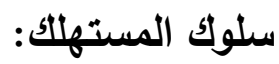


هو جانب من جوانب السلوك الإنساني، وهو التصرفات التي تتتج من الفرد نتيجة

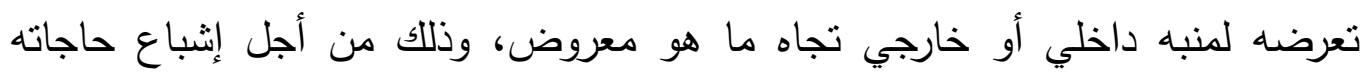
ورغباته، ويعرف بأنه ذلك السلوك الذي ييرزه المستهلك في البحث عن وشراء واستخدام السلع والخدمات التي يتوقع أنها ستشبع رغباته أو حاجاته حسب الإنكانيات الثبات الشرائية

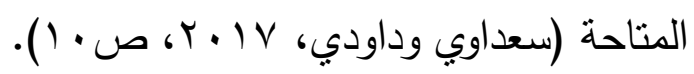

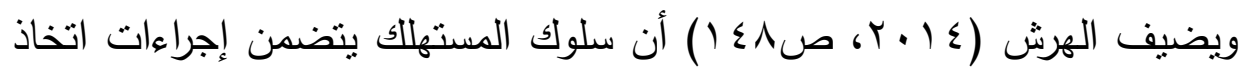

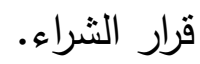
المستهـلك الفرد أو النهائي:

هو الثخص الذي يقوم بالبحث عن سلعة أو خدمة ما وشرائها لاستخدامها

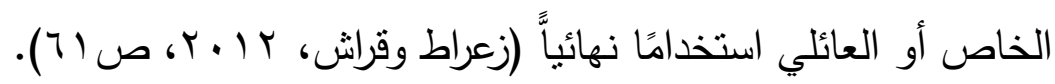

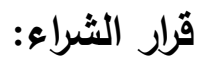

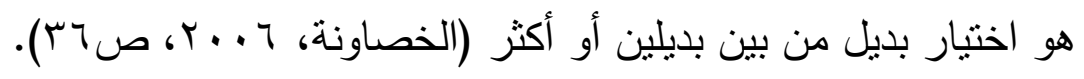

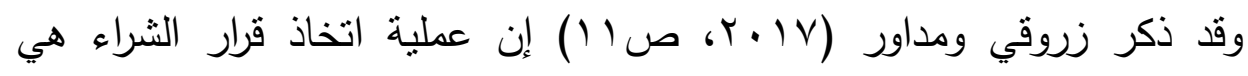
الإجراء الذي يقوم به المستهلك من خلاله بجمع المعلومات وتحليلها والاختيار بين بدائل

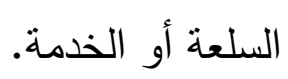

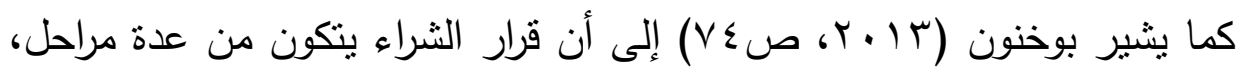

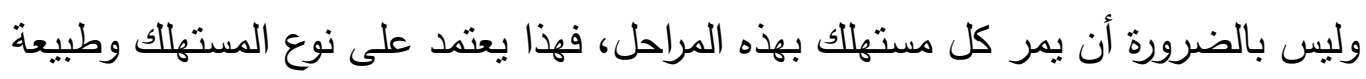

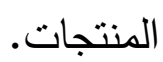
العوامل المؤثرة في سلوك المستهلك في مجال اتخاذه القرار الثرائي:

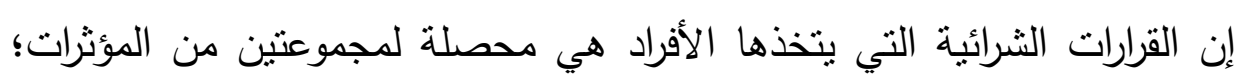
هما: العوامل البيئية والعوامل الفردية.

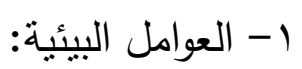
وتتضمن المؤثرات التسويقية والثقافية والاجتماعية والموققية والديموغرافية،

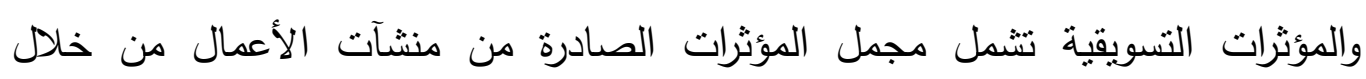




\section{الجمعية المصرية للقراعة والمعرفة عضو الجمعية الدولية للمعرفة ILA}

استراتيجياتها التسويقية وبرامجها المتعلقة بعناصر المزيج الترويجي (ناصر وماخوس،

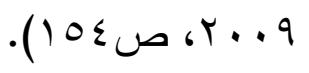

وتتشيط المبيعات من ضمن عناصر هذا المزيج.

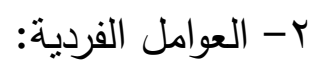

وتتضمن شخصية الفرد، والدوافع، والميول، والإدراك، والتعلم، والاتجاهات (ناصر

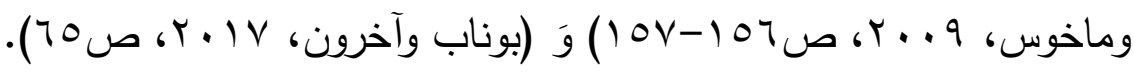

$$
\begin{aligned}
& \text { مراحل اتخاذ القرار الشرائي: - ماني } \\
& \text { أ- مراحل ما قبل الثراء: } \\
& \text { 1 - التعرف على المشكلة: }
\end{aligned}
$$

أول خطوة في اتخاذ قرار الثراء عندما يدرك المستهلك أن لديه مشكلة أو حاجة يسعى لإشباعها عند تعرضه لمنبهات داخلية أو خارجية، ويقصد بالمشكلة إدراك المستهلك

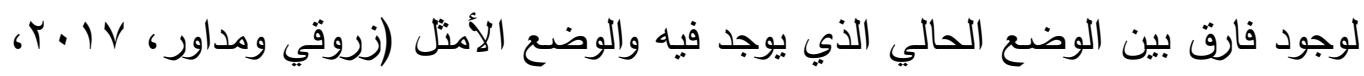

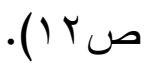

أما الحاجة فهي ذلك النقص أو العجز الحاصل لدى المستهلك تجاه بعض السلع أو الخدمات. وقسم ماسلو الحاجات إلى الحاجات الفسيولوجية، والحاجة إلى الأمان، والحاجات الاجتماعية، والحاجة إلى الاحترام، والحاجة إلى تحقيق الذات (بوخنون، (l) (r) r- r البحث عن المعلومات:

عندما يتأكد المستهلك أن لديه حاجة معينة يبدأ بالبحث عن وسائل لإثباعها من

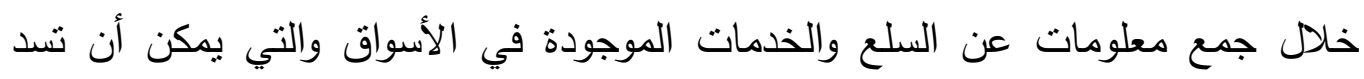

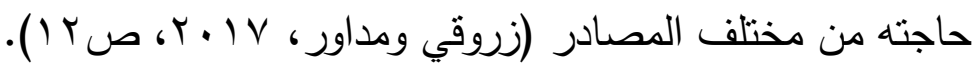

$$
\begin{aligned}
& \text { وتتقسم مصادر المعلومات إلى : } \\
& \text { (1) مصادر خارجية: وتشمل أفراد الأسرة والأقارب والجيران. }
\end{aligned}
$$


(r) مصادر تجارية: وتتمل الإعلانات ومندوبي المبيعات والكتيبات التي تصدرها

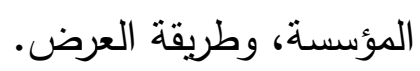

(r) مصادر عامة: المجلات والجرائد والدقالات والنشرات الحكومية، والجمعيات العلمية والهيئات التي تخدم المستهلك وتحميه، والإذاعة والتلفاز ، والإنترنت. (ع) مصادر تجريبية: تمثل استخدام السلعة من قبل المستهلك وآخرين.

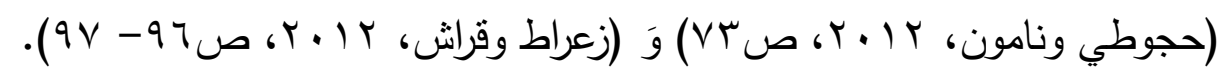

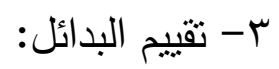

بالاعتماد على مصادر المعلومات المختلفة يحدد المستهلك البدائل من المنتجات

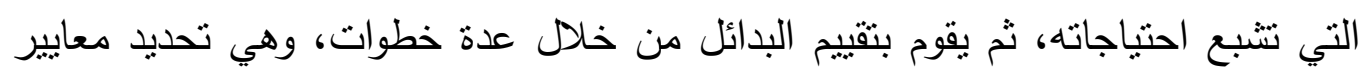

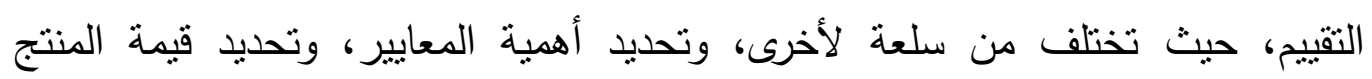
للمستهلك، ثم يختار البديل الذي يحقق له الإثباع المطلوب، ويقوم باتخاذ قرار الثراء الثاء

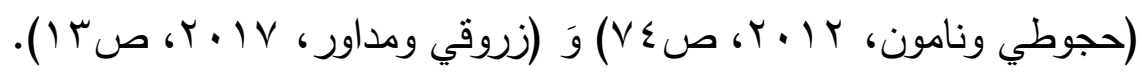

$$
\begin{aligned}
& \text { ب- قرار الثراء: }
\end{aligned}
$$

قرار الثراء يكون للصنف المفضل عند المستهلك بعد نقييم البدائل المختلفة

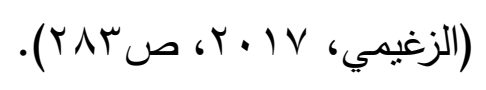

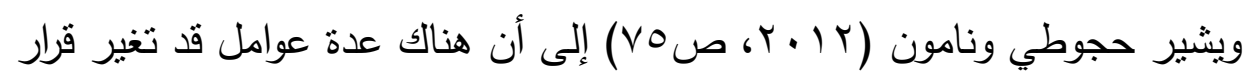

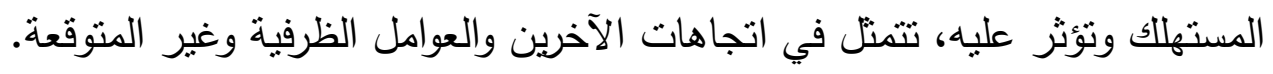

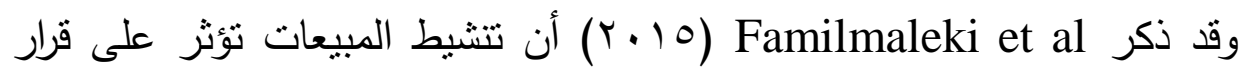

$$
\begin{aligned}
& \text { الثراء وتزيد من مشتريات المستهلكين. } \\
& \text { ج- مرحلة ما بعد الثراء: }
\end{aligned}
$$

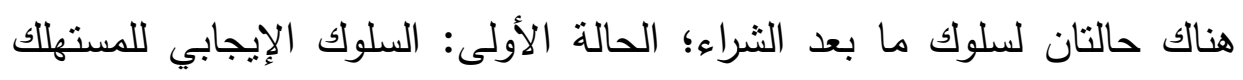

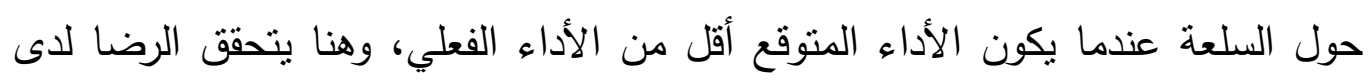

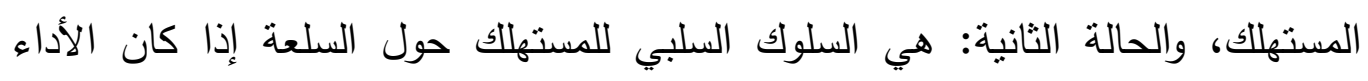




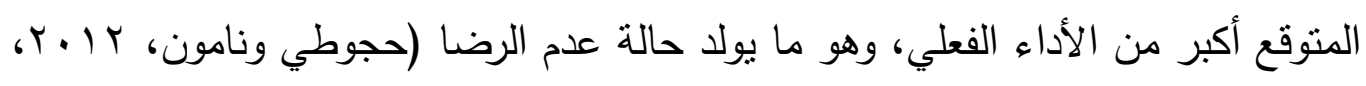
ص ص (V7)

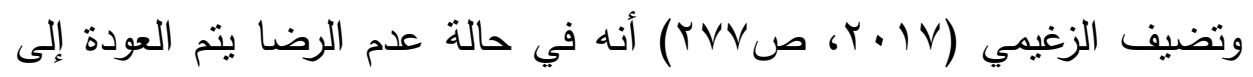
مرحلة البحث عن المعلومات وفي الأخير ينم التخلص من السلعة.

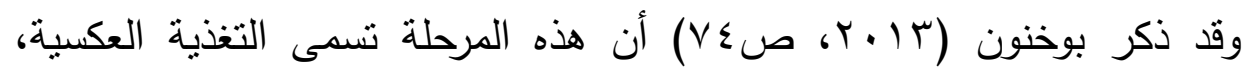

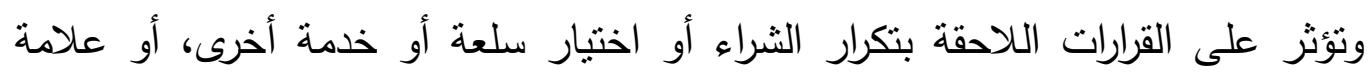
تجارية أخرى.

كما يشير Pride and Ferrell ( ب...r) إلى أن العروض الكثيرة تؤثر على عادات التنسوق للمستهلك الخاصة بتكرار الثراء. مستويات قرار شراء المستهلك:

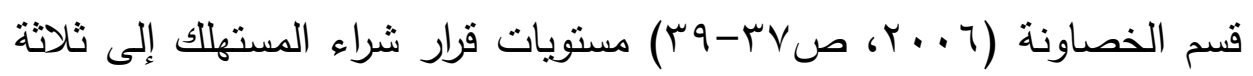

$$
\text { أقسام، وهي وفق الآتي: }
$$

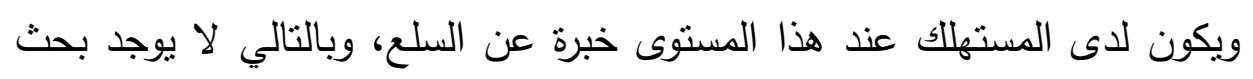

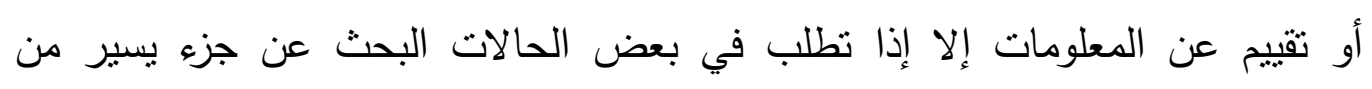

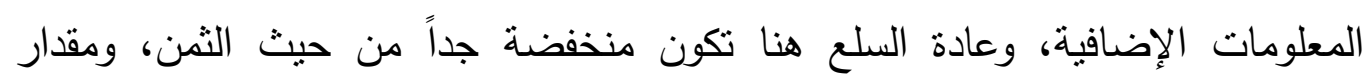
المخاطرة المدركة. r- بل مشكلة محددة:

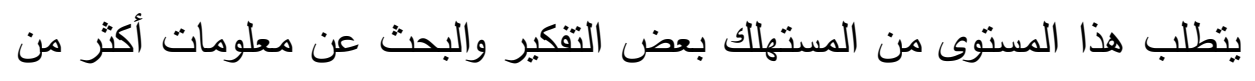

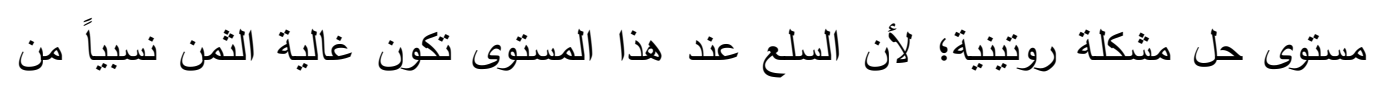

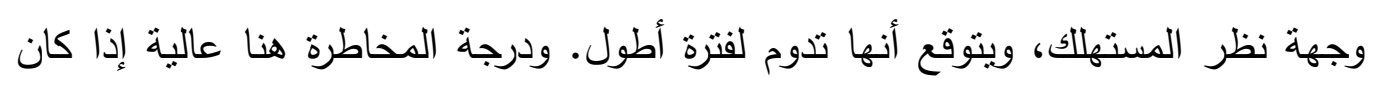
قرار الشراء خاطنًا.

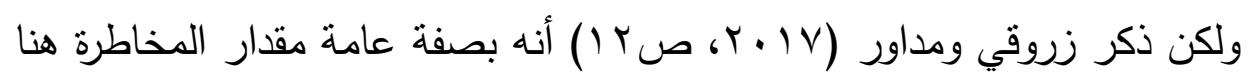
منوسطة. 


\section{ILA الجمعية المصرية للقراءة والمعرفة عضو الجمعية الدولية للمعرفة}

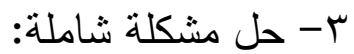

ويتطلب هذا المستوى من المستهلك الحصول على كمية كبيرة من المعلومات اللازمة لاتخاذ قرار الثراء، وكثير دن الوقت والجهد والمال، لذا يترتب عليها درجة كبيرة من المخاطرة، والمشتريات غالباً نكون بشكل غير متكرر . الأدوار في اتخاذ قرار الثراء:

1- البادي أو المقترح: هو الفرد الذي يطرح فكرة الحاجة لشراء سلعة أو خدمة. r- المؤثر: هو الفرد الذي تؤثر آراؤه ونصائحه في عملية اتخاذ قرار الشراء.

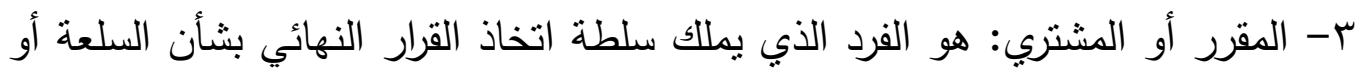

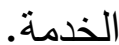

ع - المستهلك أو المستخدم: هو الفرد الذي يستخدم أو يستهلك السلعة أو الخدمة.

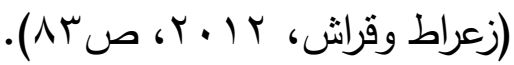

$$
\begin{aligned}
& \text { الأسلوب البحثي: } \\
& \text { منهج البحث: }
\end{aligned}
$$

استخدم في البحث الحالي المنهج الوصفي التحليلي.

$$
\text { حدود البحث: }
$$

اشتملت عينة البحث الأساسية على عينة قصدية قوامها (Y) (Y) مستهلك

سعودي بمدينة جدة يقوم بعملية التسوق في الصيدلية لثراء سلع عليها عروض تتشيط

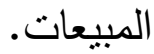

واقتصر البحث على عروض معينة من تتشيط المبيعات التي تستخدم في

$$
\text { بيانات البحثليات بكثرة. }
$$

اعتمد البحث على نوعين رئيسين من المعلومات هما: البيانات الثانوية،

والأولية.

البيانات الثانوية: 
وتتمنل في الدراسة النظرية عن طريق المسح الأكاديمي للرسائل العلمية

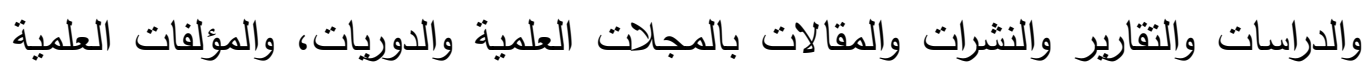
المتعلقة بموضوع البحث وذللك باللغتنين العربية والإنجليزية من مراكز البحوث والدكتبات

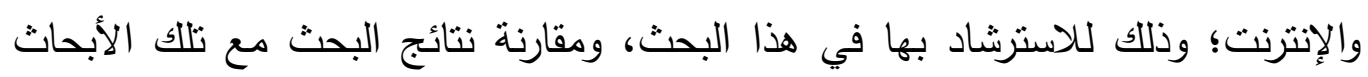
والدراسات السابقة.

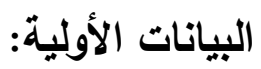
وتتمنل في الدراسة الميدانية عن طريق تصميم استمارة الاستبيان كأداة للبحث.

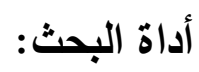
وكانت أداة البحث استبانة وزعت إلكترونيا على أفراد عينة البحث، واشتملت

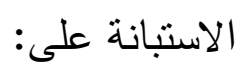
1- استمارة البيانات العامة للمتسوق، وعروض تنشيط المبيعات في الصيدلية (إعداد الباحثة): احتوت على (V) اسئلة، وتتكون من جزأين هما: البيانات العامة للمنسوق، وبيانات عروض نتشيط المبيعات في الصيدلية. ويشتمل الجزء الأول على جميع البيانات والمعلومات الأولية للمتسوق، والتي يهم الباحثة

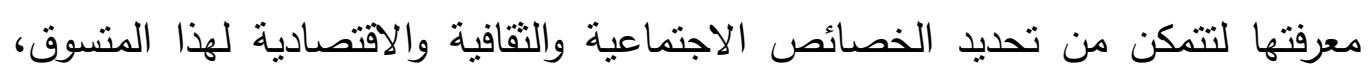

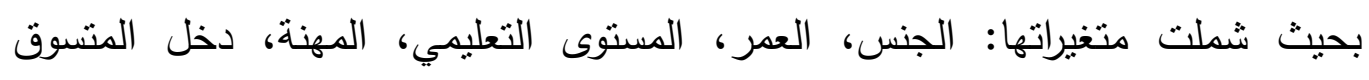
الثهري.

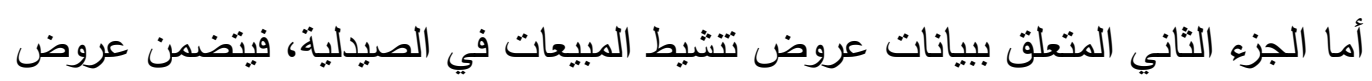

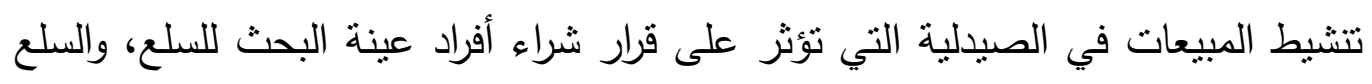
التي يتم شرائها في وقت عروض تنشيط المبيعات. r- استيان الاستجابة لعروض تنتيط المبيعات في الصيدلية (إعداد الباحثة):

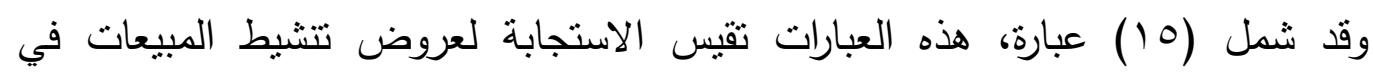

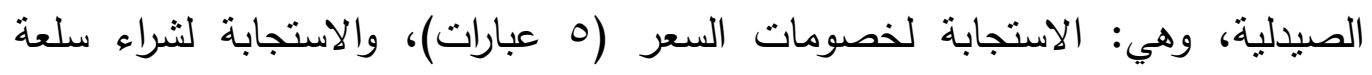
1.0 
والثانية مجاناً (0 عبارات)، والاستجابة لنقاط الثراء التي يتم تجميعها (0 عبارات)، وقد

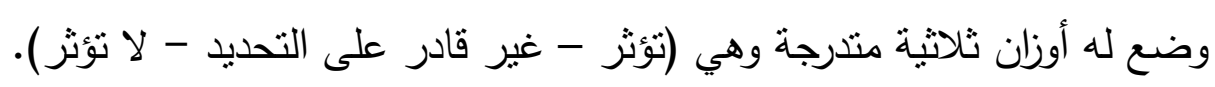
r- استبيان قرار الثراء (إعداد الباحثة):

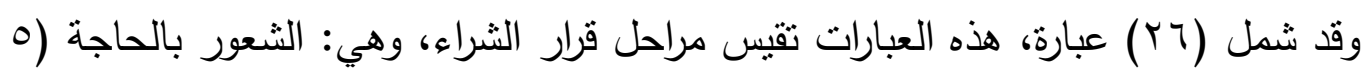

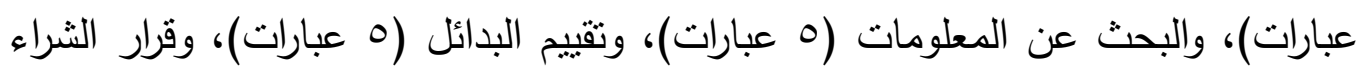

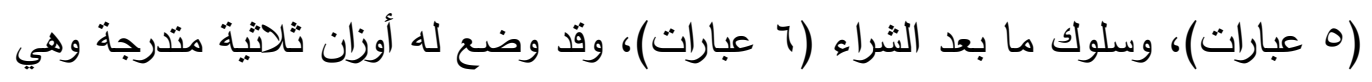

$$
\text { (نعم - أحيانًا - لا). }
$$

صدق وثبات أداة البحث

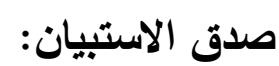

يقصد به قدرة الاستيان على قياس ما وضع لقياسه.

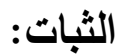

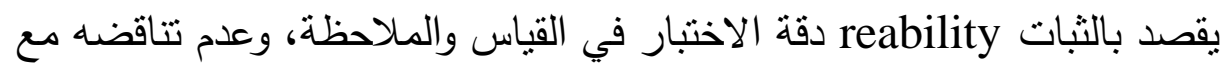

نفسه، واتساقه واطراده فيما يزودنا به من معلومات عن سلوك المفحوص، وهو النسبة بين

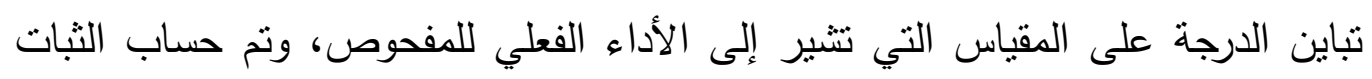
عن طريق:

Alpha Cronbach ب- معامل الفا كرونباخ Split-half بريقة التجزئة النصفية

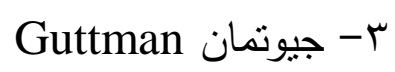

أولاً: استيبان الاستجابة لعروض تنشبط المبيعات في الصيدلية: الصدق باستخدام الاتساق الداخلي بين الارجة الكلية لكل محور والدرجة الكلية

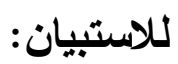

تم حساب الصدق باستخدام الاتساق الداخلي وذلك بحساب معامل الارتباط

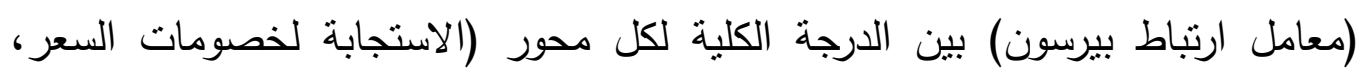

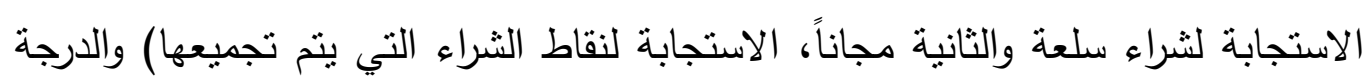




\section{ILA الجمعية المصرية للقراءة والمعرفة عضو الجمعية الدولية للمعرفة}

الكلية للاسنتيان، والجدول التالي يوضح ذلك:

جدول ( 1) قيم معاملات الارتباط بين درجة كل محور ودرجة استبيان الاستجابة لعروض تنثيط

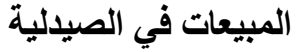

\begin{tabular}{|c|c|c|}
\hline الالالة & الارتباط & \\
\hline$\because \cdot 1$ & $.91 \%$ & المحور الأول: الاستجابة لخصومات السعر \\
\hline$\because \cdot 1$ & $\cdot . \wedge \wedge 0$ & المحور الثانى: الاستجابة لثراء سلعة و الثانية مجاناً \\
\hline$\because \cdot 1$ &.$V Y \mu$ & المحور الثالث: الاستجابة لنقاط الثر اء التي يتم تجميعها \\
\hline
\end{tabular}

يتضح من الجدول أن معاملات الارتباط كلها دالة عند مستوى (1 .. . لاقترابها

من الواحد الصحيح مما يدل على صدق وتجانس محاور الاسنبيان.

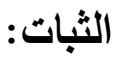

جدول (r) قيم معامل الثبات لمحاور استبيان الاستجابة لعروض تنثيط المبيعات في الصيدلية

\begin{tabular}{|c|c|c|c|}
\hline جيوتمان & التجزئة النصفية & 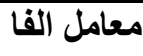 & المحاور \\
\hline$\cdot . \mathrm{VTr}$ & $\because \vee \wedge q-\cdot . \vee 1 Y$ & $\cdot V \leqslant V$ & المحور الأول: الاستجابة لخصومات السعر \\
\hline$\cdot . \wedge 91$ & $\cdot .9 \leq 0-\cdot . \mathrm{AVr}$ & $\cdot .9 \cdot r$ & المحور الثاني: الاستجابة لثراء سلعة و الثانية مجاناً \\
\hline$\therefore \vee V 7 \leqslant$ & $\cdot \Lambda \mid r-\cdot . V \leq$. & $\therefore \vee \vee \vee q$ & المحور الثالث: الاستجابة لنقاط الثراء التى يتم تجميعها \\
\hline$\cdot$.AYI & $\cdot \wedge \vee \cdot-\cdot \wedge \cdots$ & $\cdot . \wedge r \uparrow$ & ثبات استبيان الاستجابة لعروض تنشيط المبيعات في الصبيلية ككل \\
\hline
\end{tabular}

يتضح من الجدول السابق أن جميع قيم معاملات الثبات: معامل الفا، التجزئة النصفية، جيوتمان دالة عند مستوى ا +.. . مما يدل على ثبات الاستبيان. ثانياً: استبيان قرل الثراء

الصــق باسـتخدام الاتســاق الـداخلي بـين الدرجـة الكليـة لكـل محسور واللارجـة الكليـة

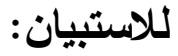

تم حساب الصدق باستخدام الاتساق الداخلي وذلك بحساب معامل الارتباط (معامل ارتباط بيرسون) بين الدرجة الكلية لكل محور (الثعور بالحاجة، البحث عن المعلومات، تقييم البدائل، قرار الثراء، سلوك ما بعد الثراء) والدرجة الكلية للاستبيان، والجدول التالي يوضح ذلك: جدول (ّ) قيم معاملات الارتباط بين درجة كل محور ودرجة استبيان قرار الثراء 


\begin{tabular}{|c|c|c|}
\hline 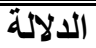 & الارتباط & \\
\hline$\because \cdot 1$ & •. ^५ & المحور الأول: الثعور بالحاجة \\
\hline$\because \cdot 1$ & $\cdot .9 .8$ & المحور الثاني: البحث عن المعلومات \\
\hline$\because \cdot 1$ & $\because v 09$ & المحور الثثالث: تقييم البدائل \\
\hline. .1 & $\cdot \Delta 1 r$ & المحور الرابع: قرار الثراء \\
\hline. .1 & .947 & المحور الخامس: سلوك ما بعد الثراء \\
\hline
\end{tabular}

يتضح من الجدول أن معاملات الارتباط كلها دالة عند مستوى (1 ... لاقترابها من الواحد الصحيح مما يدل على صدق وتجانس محاور الاستبيان.

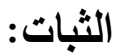

جدول ( ) قيم معامل الثبات لمحاور استبيان قرار الثراء

\begin{tabular}{|c|c|c|c|}
\hline جيوتمان & التجزئة النصفية & معامل الفا & المحاور \\
\hline$\because V \vee r$ & $\cdot . \wedge Y \neg-\cdot . V \otimes 0$ & $\because \vee \vee \wedge \wedge$ & المحور الأول: الثعور بالحاجة \\
\hline$\cdot . \wedge \Gamma$ & $\cdot . \wedge \wedge q-\cdot . \wedge 11$ & $\cdot \wedge \leqslant Y$ & المحور الثانى: البحث عن المعلومـات \\
\hline$\cdot .9 \cdot v$ & $. .90 r-\cdot . \wedge \Lambda r$ & .914 & المحور الثثالث: تقينم البدائل \\
\hline$\because V \leqslant 0$ & $\because V q \cdot-\cdot . V Y Y$ & $\because \mathrm{V} \odot \mathrm{V}$ & المحور الرابع: قرار الثراء \\
\hline $.91 r$ & $\cdot .974-\cdot . \wedge 91$ & $\cdot .9 \mathrm{rV}$ & المحور الخامس: سلوك ما بعد الثراء \\
\hline.$\vee \vee 91$ & $\cdot . \wedge \leqslant 0-\cdot . V \vee r$ & $\cdot . \wedge .0$ & ثبات استبيان قرار الثراء ككل \\
\hline
\end{tabular}

يتضح من الجدول السابق أن جميع قيم معاملات الثبات: معامل الفا، التجزئة النصفية، جيوتمان دالة عند مستوى ا ... . مما يدل على ثبات الاستبيان. وصف عينة البحث: استمارة البيانات العامة للمتسوق، وعروض تنشيط المبيعات في الصيدلية: أولاً: البيانات العامة للمتسوق: وتشمل المتغيرات الاجتماعية والثقافية والاقتصادية للمتسوق. 1- الجنس: يوضح الجدول (0) والثكل البياني رقم (1) توزيع أفراد عينة البحث تبعاً لمتغير الجنس. جدول (•) توزيع أفراد عينة البحث تبعاً لمتغير الجنس 
الجمعية المصرية للقراعة والمعرفة عضو الجمعية الدولية للمعرفة ILA

\begin{tabular}{|c|c|c|}
\hline النسبة\% & العدد & الجنس \\
\hline \% \% Y. & $\vee \wedge$ & ذكر \\
\hline$\%$ & 171 & أنثي \\
\hline$\%$ & $r r q$ & المجموع \\
\hline
\end{tabular}

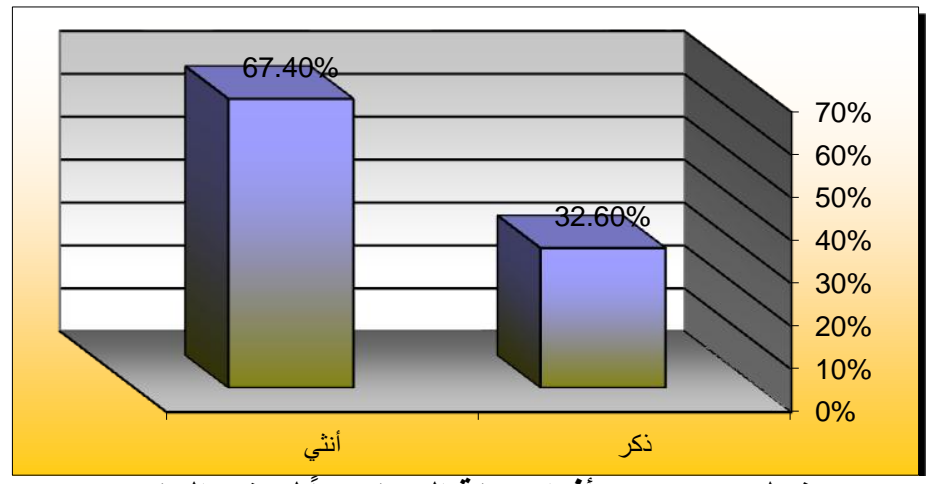

شكل ( ) توزيع أفراد عينة البحث تبعاً لمتغير الجنس

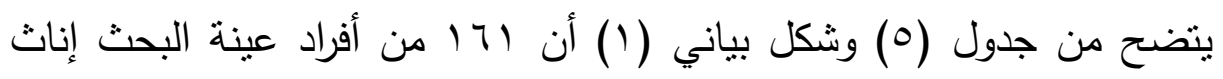

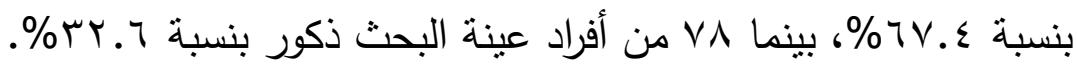

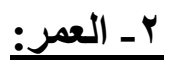

يوضح الجدول (؟) والثكل البياني رقم (؟) توزيع أفراد عينة البحث تبعاً لمتغير

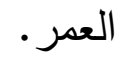

جدول (†) توزيع أفراد عينة البحث تبعاً لمتغير العمر

\begin{tabular}{|c|c|c|}
\hline 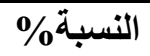 & العدد & العمر \\
\hline$\%$ \%r. & $0 \leqslant$ & أقلّ من · ب سنة \\
\hline$\%$ \%q.r $^{r}$ & v. & من · r سنة لأقلّل من · ؛ سنة \\
\hline$\% \leqslant \wedge .1$ & 110 & من · ك سنة فأكثر \\
\hline$\% 1 \ldots$ & rrq & 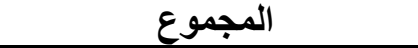 \\
\hline
\end{tabular}




\section{الجمعية المصرية للقراءة والمعرفة عضو الجمعية الدولية للمعرفة ILA}

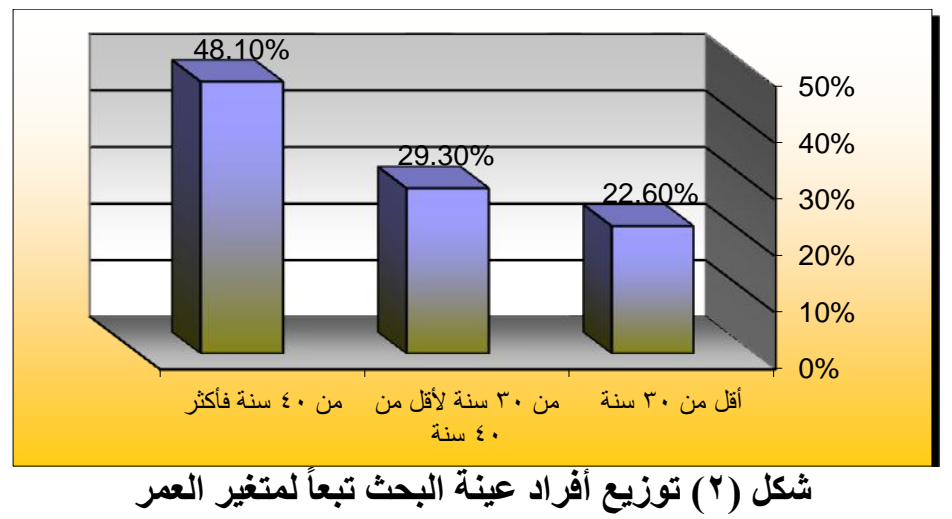

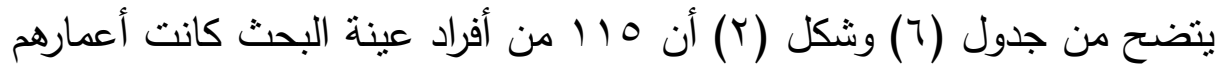

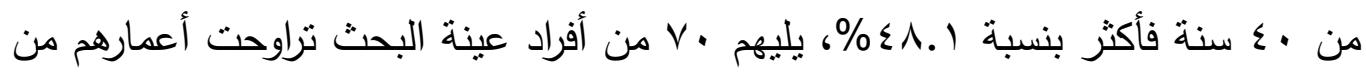

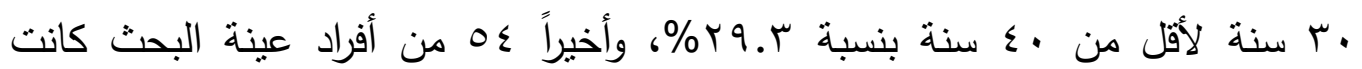

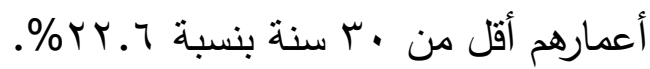

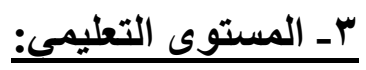
يوضح الجدول (V) والثكل البياني رقم (r) توزيع أفراد عينة البحث تبعاً لـتغير

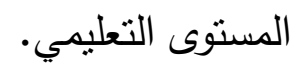

جدول (V) توزيع أفراد عينة البحث تبعاً لمتغير المستوى التعليمي

\begin{tabular}{|c|c|c|}
\hline النسبة\%\% & العدد & المستوى التعليمي \\
\hline$\% 10.9$ & re & شهادة متوسطة فأقلّل \\
\hline$\%$ \%r.r & VV & شهادة ثانوية / دبلوم \\
\hline$\% 01.9$ & IY & شهادة جامعية / ماجستير، دكتوراه \\
\hline$\%$ & & المجموع \\
\hline
\end{tabular}




\section{الجمعية المصرية للقراءة والمعرفة عضو الجمعية الدولية للمعرفة ILA}

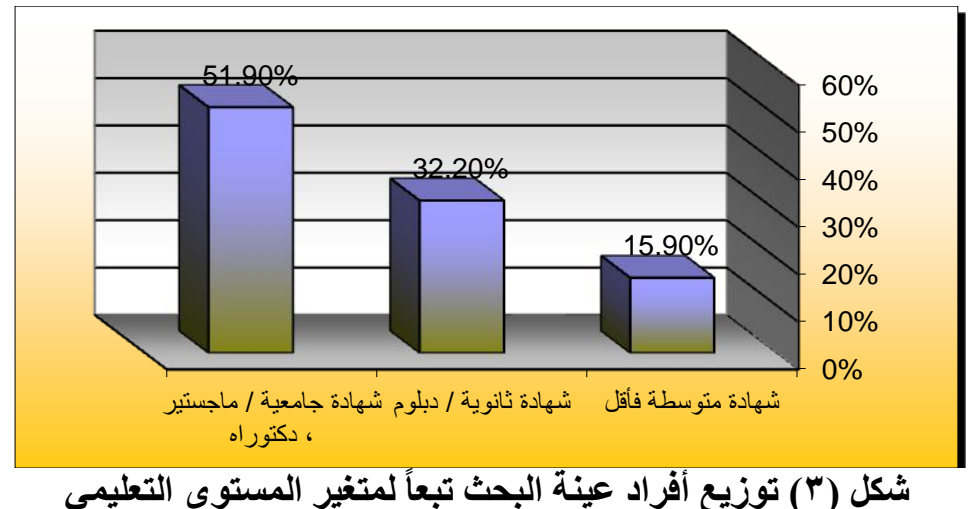

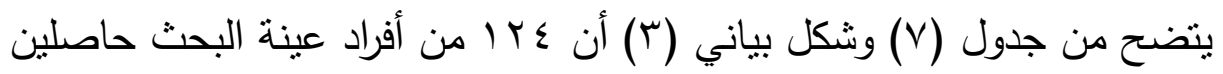

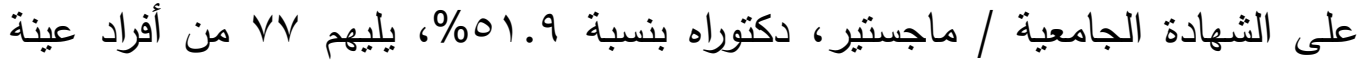

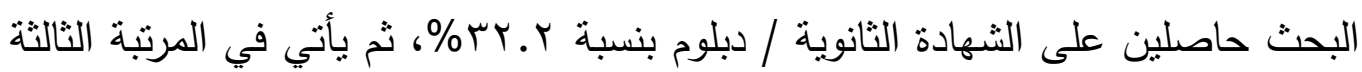

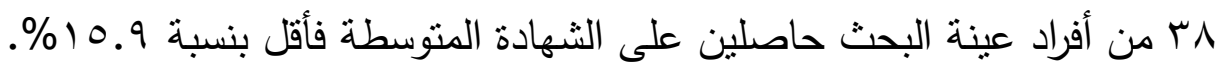

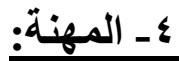

يوضح الجدول (^) والثكل البياني رقم (ع) توزيع أفراد عينة البحث تبعاً لـتغير

المهنة.

جدول (^) توزيع أفراد عينة البحث تبعاً لمتغير المهنة

\begin{tabular}{|c|c|c|}
\hline |النسبة\%\% & العدد & المهنة \\
\hline$\% 04.9$ & 144 & يعمل \\
\hline$\% \leqslant r .1$ & 1.4 & لا يعمل \\
\hline$\%$ & req & المجموع \\
\hline
\end{tabular}

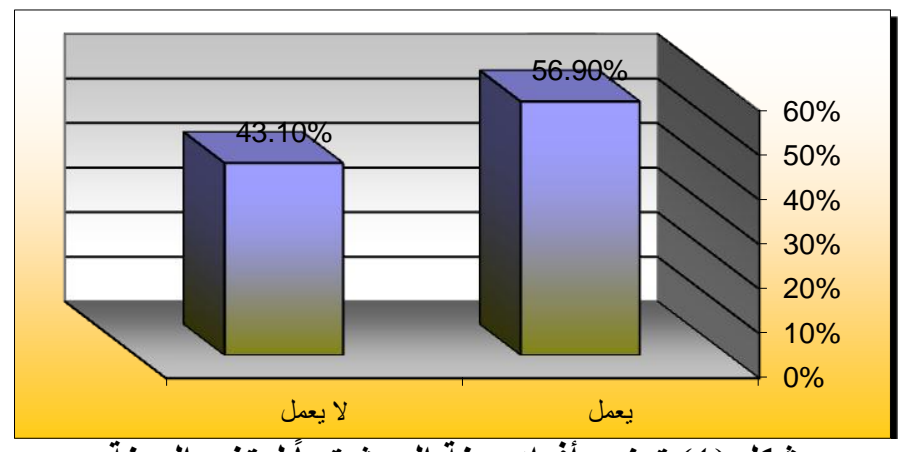

شكل ( ) ) توزيع أفراد عينة البحث تبعأ لمتغير المهنة 


\section{الجمعية المصرية للقر اءة و المعرفة عضو الجمعية الدولية للمعرفة}

يتضح من جدول (^) وشكل (ع) أن جrا من أفراد عينة البحث عاملين بنسبة

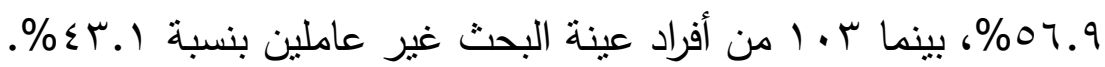

هـ الاخل الشهري:

يوضح الجدول (9) والثكل البياني رقم (0) توزيع أفراد عينة البحث وفقاً لفئات

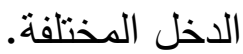

جدول (9) توزيع أفراد عينة البحث وفقاً لفئات الاخل المختلفة

\begin{tabular}{|c|c|c|}
\hline النسبة\% & 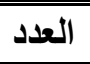 & الاخل الشهري \\
\hline$\%$ \%V. & 79 & أقل من · . \\
\hline$\%$ \%..9 & 0 . & 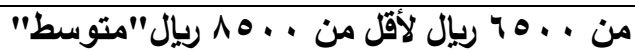 \\
\hline$\% 01.0$ & IrT & من . مه ريال فَأكثر "مرتفع" \\
\hline$\%$ & rrq & المجموع \\
\hline
\end{tabular}

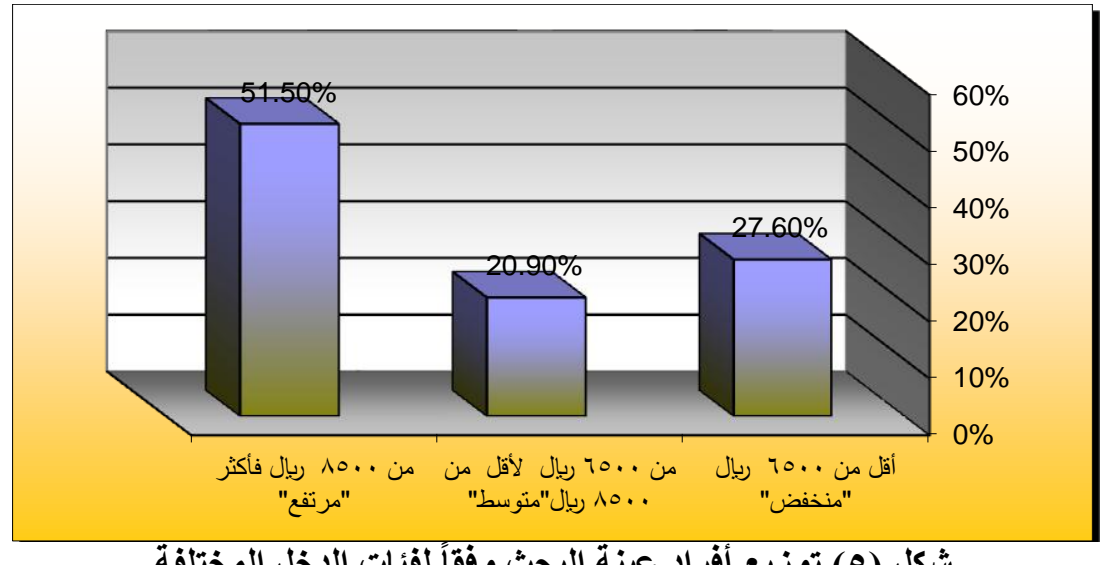

شكل (0) توزيع أفراد عينة البحث وفقاً لفئات الدخل المختلفة

يتضح من جدول (9) وشكل (0) أن بrا ما من أفراد عينة البحث دخلهم من

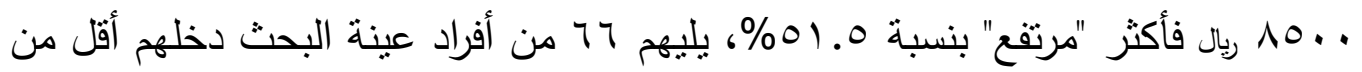

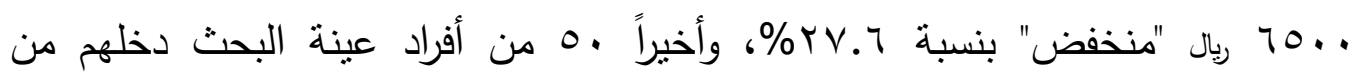

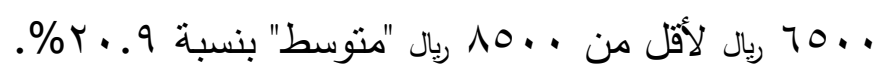

ثنائًا: بيانات عروض تنثيط المبيعات في الصيدلية:

تتضمن عروض تتشيط المبيعات في الصيدلية التي تؤثر على قرار شراء أفراد 


\section{الجمعية المصرية للقراعة والمعرفة عضو الجمعية الدولية للمعرفة ILA}

عينة البحث للسلع، والسلع التي يتم شرائها في وقت عروض تتشيط المبيعات. 1 - عروض تثشبط المبيعات في الصيدلية التي تؤثر على قرل شراء أفراد عينة البحث

للسلع:

يوضح الجدول (• () والثكل البياني رقم (؟) عروض تتشيط المبيعات التي تؤُثر على قرار شراء أفراد عينة البحث للمنتجات.

جدول ( • 1) عروض تنشيط المبيعات في الصيدلية التي تؤثر على قرار شراء أفراد عينة البحث للسلع

\begin{tabular}{|c|c|c|}
\hline النسبة\% & 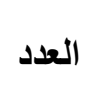 & 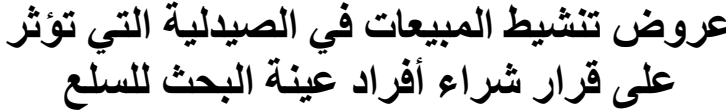 \\
\hline$\%$ \%o.q & IVo & خصومات السعر \\
\hline$\%$ \% & $1 \cdot \varepsilon$ & شر اء سلعة والثانية مجاناً \\
\hline$\% \vee .9$ & $r q$ & كمية إضافية مجانية \\
\hline$\% 0 . r$ & rq & الهـايا \\
\hline$\% 9.7$ & $\varepsilon V$ & عينات مجاتية \\
\hline$\% \vee . Y$ & ro & تنظيم العرض داخل الصيدلية \\
\hline$\%\urcorner . \wedge$ & $r r$ & نقاط الثراء التي يتم تجميعها \\
\hline$\% 0.9$ & rq & نشرات، وكتيبات، وكتالوجات عن المنتج \\
\hline$\overline{\%} 1 \ldots$ & $\varepsilon \wedge \Lambda$ & المجموع \\
\hline
\end{tabular}

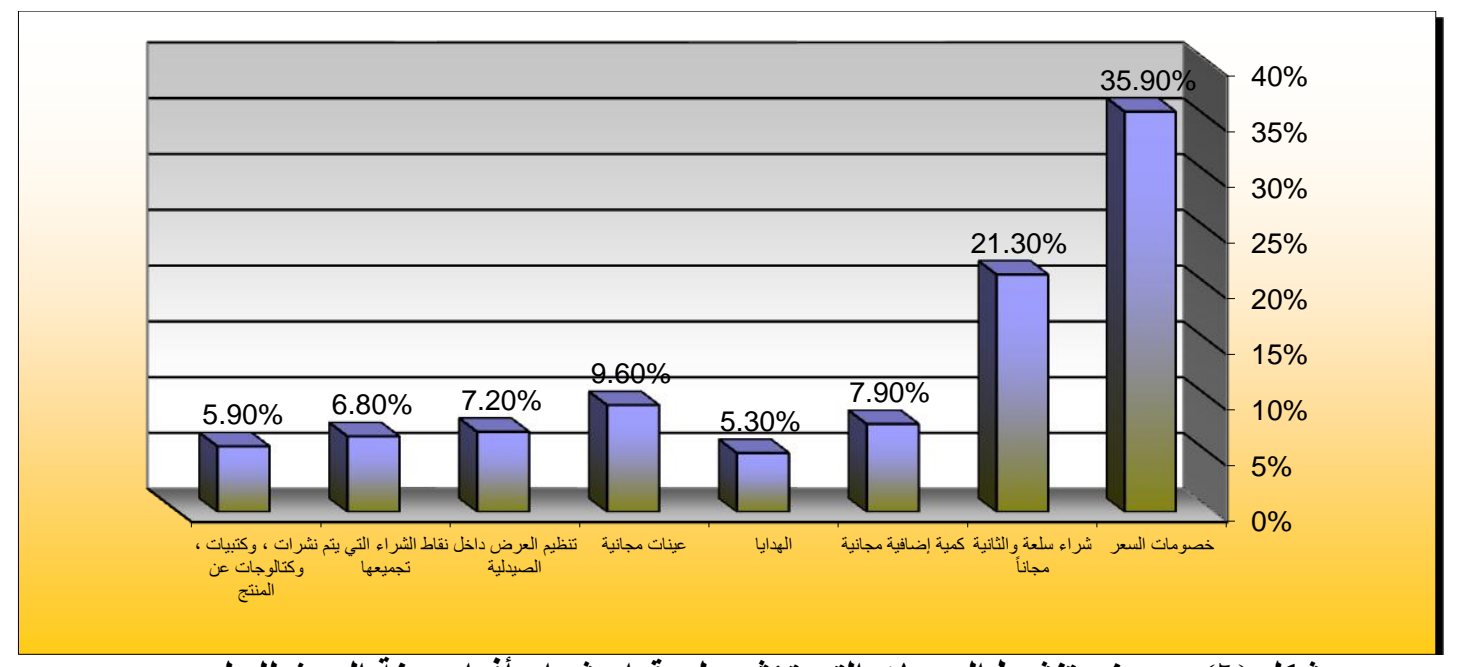

شكل (†) عروض تنشيط المبيعات التي تؤُثر على قرار شراء أفراد عينة البحث للسلع

يتضح من جدول (·(1) وشكل (T) أن V0 من أفراد عينة البحث كانت 


\section{ILA الجمعية المصرية للقراءة والمعرفة عضو الجمعية الدولية للمعرفة}

خصومات السعر تؤثز على قرارات شرائهح بنسبة 0.9\%\%، يليهم ؟ ـ. من أفراد عينة

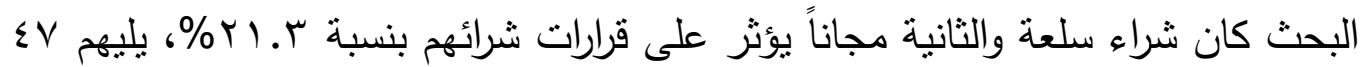

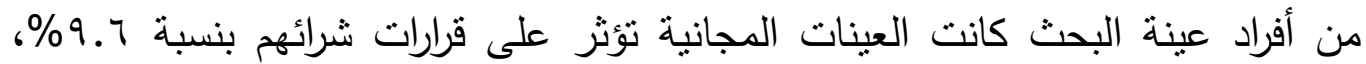

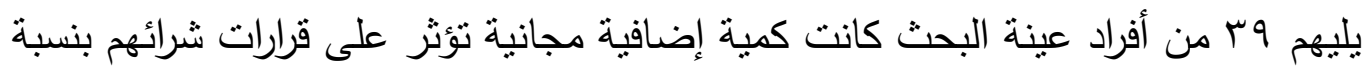

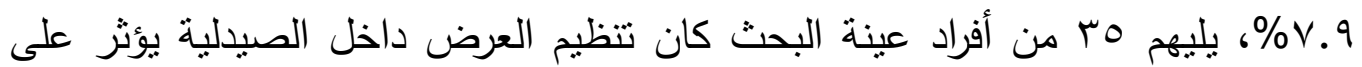

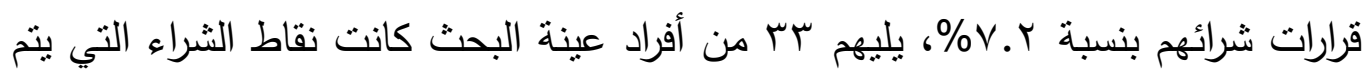

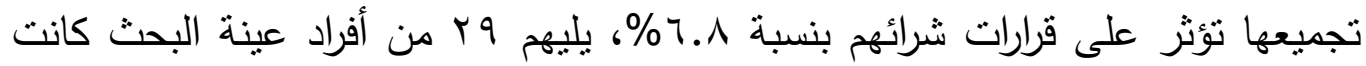
النشرات، والكتيات، والكتالوجات عن المنتج تؤثز على قرارات شرائهم بنسبة 0.9\%،

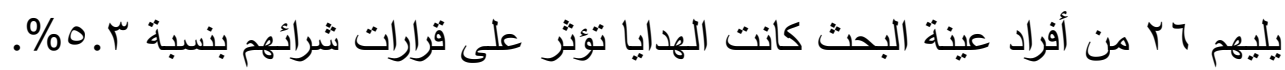
r - السلع التي يشتريها أفراد عينة البحث في وقت عروض تنشبط المبيعات: يوضح الجدول (ll) والثكل البياني رقم (V) السلع التي يشتربها أفراد عينة البحث في وقت عروض تنشيط المبيعات.

جدول (11) السلع التي يشتريها أفراد عينة البحث في وقت عروض تنشيط المبيعات

\begin{tabular}{|c|c|c|}
\hline النسبة\% & العدد العد & السلع التي يشتريها أفراد عينة البحث في وقت المبيعات \\
\hline$\overline{\%} / 9.4$ & $T 4$ & أدوية \\
\hline$\% \leqslant \wedge .7$ & $10 \mathrm{~V}$ & مستحضرات العناية والتجميل \\
\hline \%Mr.r & $1 \cdot \varepsilon$ & أدوات وأجهزة \\
\hline$\%$ & TYY & المجموع \\
\hline
\end{tabular}




\section{الجمعية المصرية للقراءة والمعرفة عضو الجمعية الدولية للمعرفة ILA}

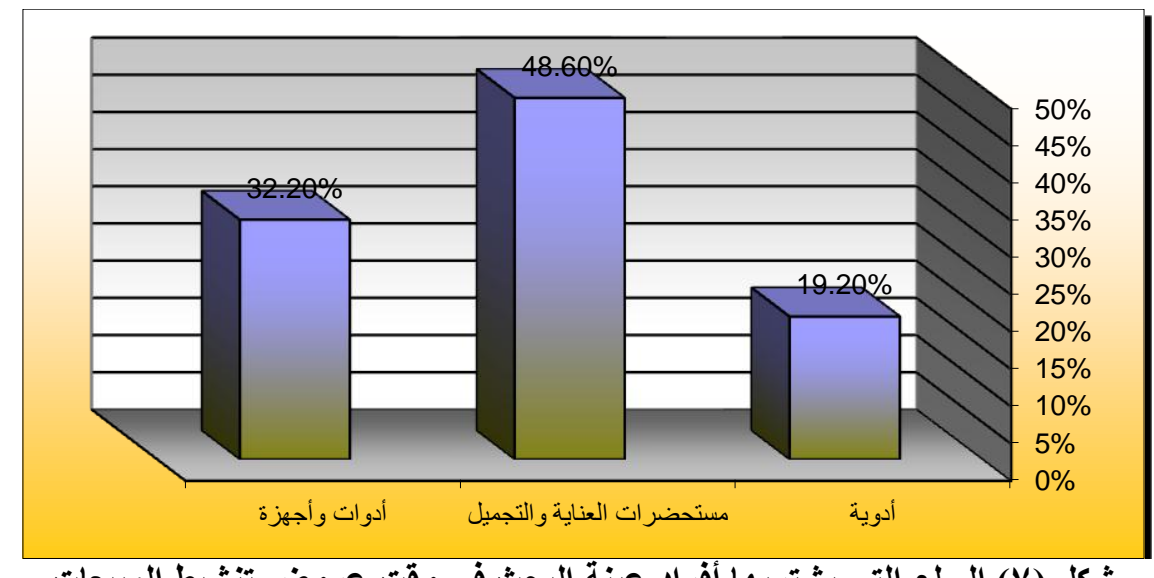

شكل (V) السلع التي يشتريـا أفراد عينة البحث في وقت عروض تنشيط المبيعات

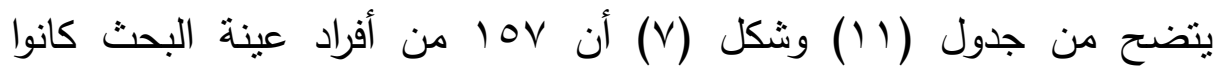

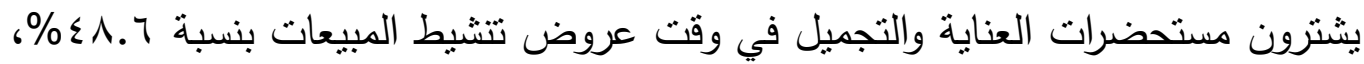

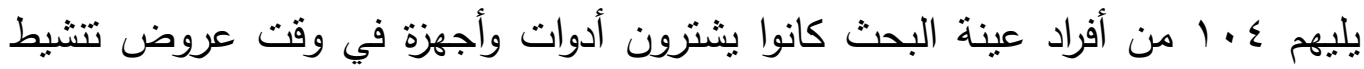

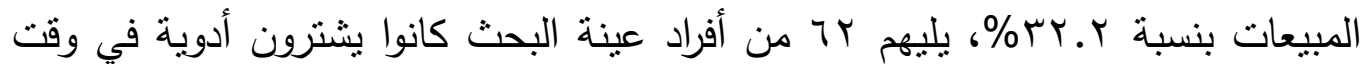
عروض تنشيط المبيعات بنسبة ب.9 19\%.

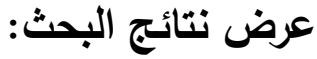

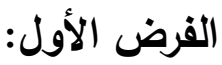

توجد علاقة ارتباطية بين الوعي للاستجابة لعروض تتشيط المبيعات في الصيالية ورشد

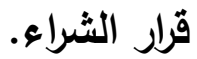

وللتحقق من صحة هذا الفرض تم عمل مصفوفة ارتباط بين محاور استبيان الاستجابة لعروض تتشيط المبيعات في الصيدلية ومحاور استبيان قرار الثراء والجدول النالي يوضح قيم معاملات الارتباط:

جدول (^^) مصفوفة الارتباط بين محاور استبيان الاستجابة لعروض تنثيط العبيعات في الصيالية ومحاور استبيان قرار الثراء لاء

\begin{tabular}{|c|c|c|c|c|c|c|}
\hline الثراء كرارل & بد الثراء ماء & الثراء & البدائل & البعلومات عن & بالأشعور & \\
\hline$* * . \wedge r q$ & $* * . . v \cdot q$ & $* .711$ & $* * .9 \cdot 1$ & $* * ., \wedge \wedge 1$ & $* * . \vee \vee r^{\prime}$ & الاستجابة لخصومات السعر \\
\hline
\end{tabular}


ILA الجمعية المصرية للقر اءة والمعرفة عضو الجمعية الدولية للمعرفة

\begin{tabular}{|c|c|c|c|c|c|c|}
\hline$* * . V \varepsilon$. & $* * .979$ & $* * . . V 01$ & $* * . V I Y$ & $* . .7 \cdot 0$ & $* * \cdot . \wedge Y$ & الاستجابة لشر اع سلعة و الثانية مجانًاً \\
\hline$* * . . \vee 91$ & $* .7 \% q$ & $* * \cdot . \Lambda \cdot \Lambda$ & $* . .7 Y$. & $* * . \wedge \curlyvee \varepsilon$ & $* * .91 \%$ & الاستجابة لنقاط الشراء التي يتم تجميعها \\
\hline$* * \cdot . \wedge \vee \mu$ & $* * \wedge \wedge \bullet 0$ & $* *$. VYr & $* * . . \wedge 9$. & $* * . \wedge \mu \Delta$ & $* * . . \vee 79$ & الاستجابة لعروض تنشيط المبيعات في \\
\hline
\end{tabular}

يتضح من الجدول (r^) وجود علاقة ارتباط طردي بين الوعي للاستجابة

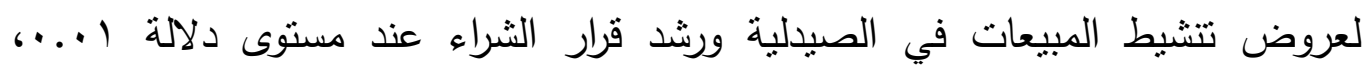

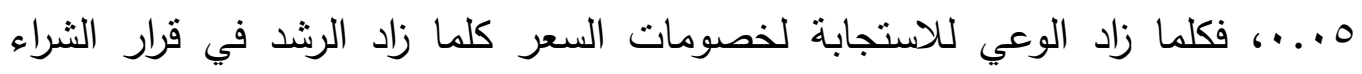

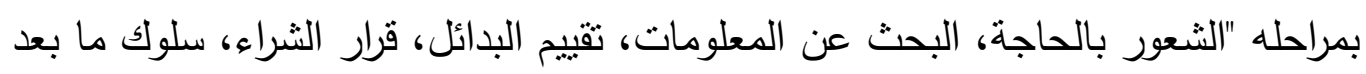

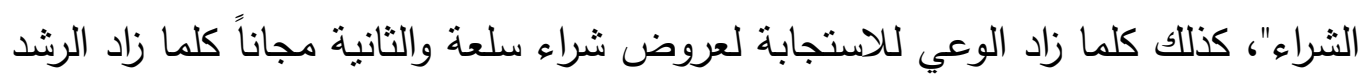

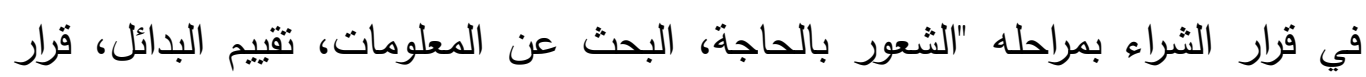

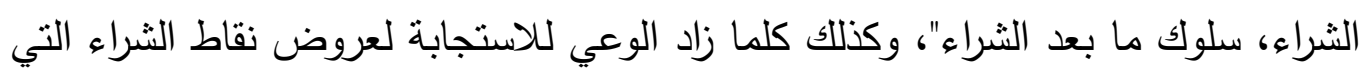

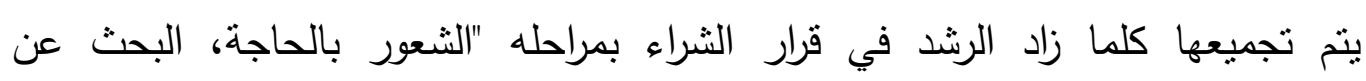

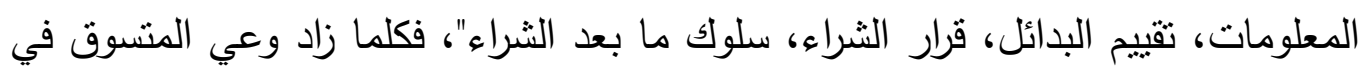
الاستجابة لعروض تتشيط المبيعات في الصيدلية كلما زاد الرشد في قرار الثراء بمراحله

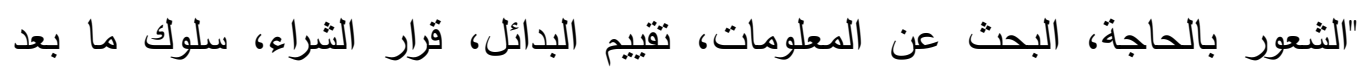

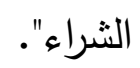

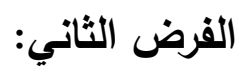

توجد فروق ذات دلالة إحصائية بين متوسط درجات أفراد العينة في وعيهم للاستجابة لعروض تنشيط المبيعات في الصيدلية تبعاً لمتغيرات الدارسة. وللتحقق من هذا الفرض تم تطبيق اختبار (ت)، وحساب تحليل التباين لدرجات

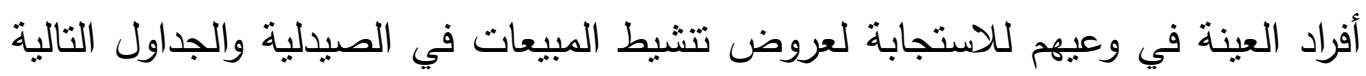
توضح ذلك:

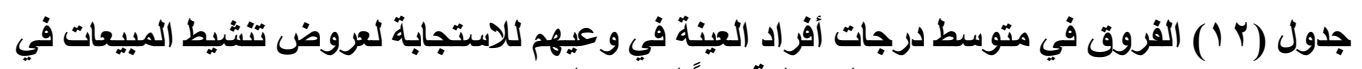

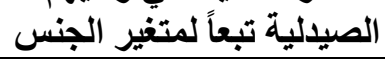
اللالالة
قيمة (ت)
الدرجات

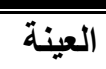
الانحراف
المتوسط
الجنس 
الجمعية المصرية للقراءة والمعرفة عضو الجمعية الدولية للمعرفة ILA

\begin{tabular}{|c|c|c|c|c|c|c|}
\hline & & الحرية & & المعياري & الحسابي & \\
\hline \multirow{2}{*}{ لدال عند الث الإناث } & \multirow{2}{*}{$1 . .74$} & \multirow{2}{*}{ rmV } & $\vee \wedge$ & Y.\$1. & $r \wedge . \wedge Y V$ & ذكر \\
\hline & & & 171 & A & \& Y.r. & أنثح \\
\hline
\end{tabular}

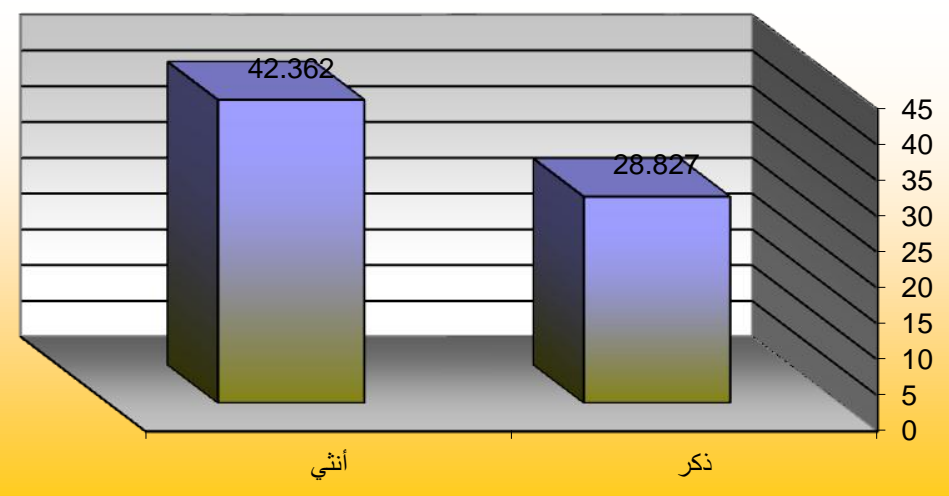

شكل (^) الفروق في متوسط درجات أفراد العينة في وعيهم للاستجابة لعروض تنشيط المبيعات في

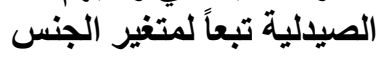

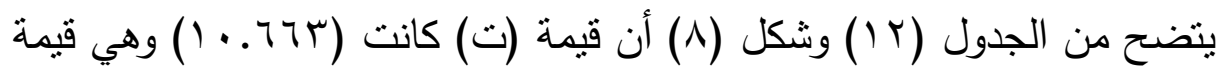

دالة إحصائيا عند مستوى دلالة (1 (. . ) لصالح الإناث، حيث بلغ متوسط درجة الإناث

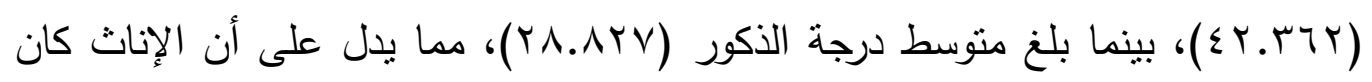
وعيهن للاستجابة لعروض تتشيط المبيعات في الصيدلية أكثر من الذكور .

جدول (r ا ) تحليل التباين لارجات أفراد العينة في وعيهم للاستجابة لعروض تنثيط المبيعات في تي

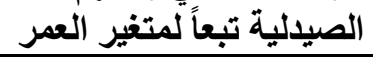

\begin{tabular}{|c|c|c|c|c|c|}
\hline الالالة & قيمة (ف) & الحرجية & متوسط المربعات & مجموع المربعات & العمر \\
\hline \multirow{3}{*}{ '•• } & \multirow{2}{*}{ rV.YAY } & $\bar{r}$ & $r \cdot \wedge 0.7 \mu r$ & $71 V 1.470$ & بين المجموعات \\
\hline & & צrמץ & AY.VYo & $190 Y_{0} 010$ & داخل المجموعات \\
\hline & & $r r \Lambda$ & & rOV.r.VA. & المجموع \\
\hline
\end{tabular}

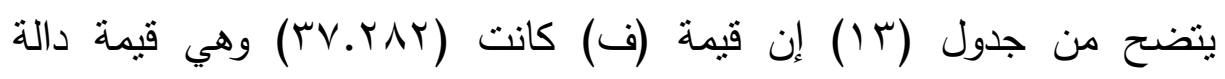

إحصائيا عند مستوى (1 ....)، مما يدل على وجود فروق بين درجات أفراد العينة في وعيهم للاستجابة لعروض تتشيط المبيعات في الصبدلية تبعاً لمتغير العمر ، ولمعرفة اتجاه 
الجمعية المصرية للقراعة والمعرفة عضو الجمعية الدولية للمعرفة ILA الدلالة تم تطبيق اختبار LSD للمقارنات المتعددة والجدول التالي يوضح ذللك: جدول ( 1 ) اختبار LSD للمقارنات المتعددة

\begin{tabular}{|c|c|c|c|}
\hline 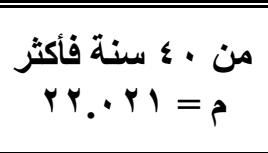 & من من · معنة سنة لأقلّ & 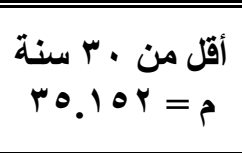 & العمر - الع \\
\hline & & - & أقلّ من · سنة \\
\hline & - & $* * 1 \cdot . \wedge 17$ & من · r سنة لأقلّل من · ؛ سنة \\
\hline - & $* r . r 10$ & $* *|r| r \mid$. & من · ع سنة فأكثر \\
\hline
\end{tabular}

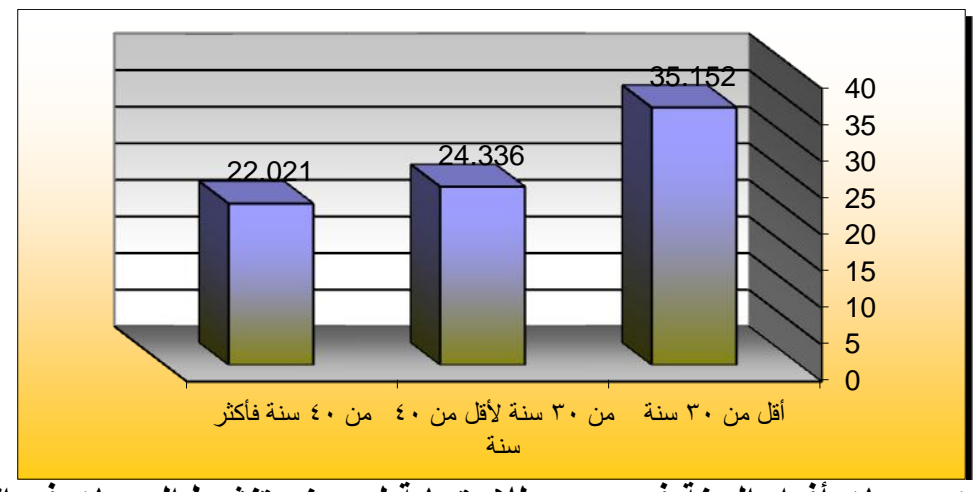

شكل (9) فروق درجات أفراد العينة في وعيهم للاستجابة لعروض تنثيط المبيعات في الصيلية تبعاً

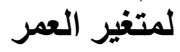

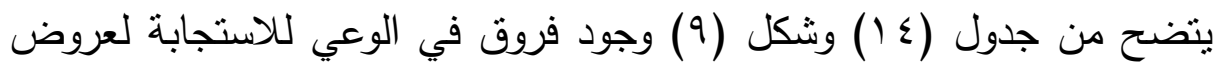

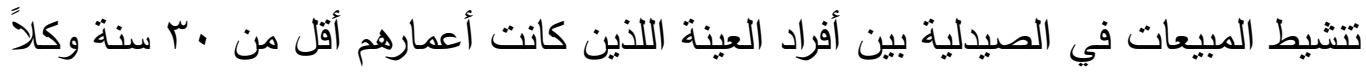

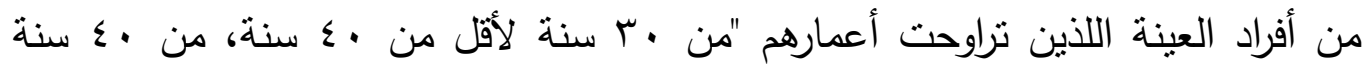

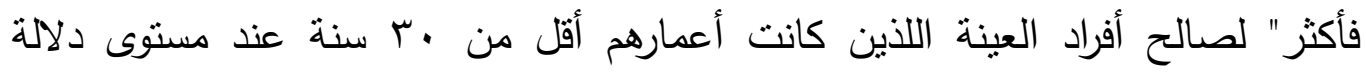

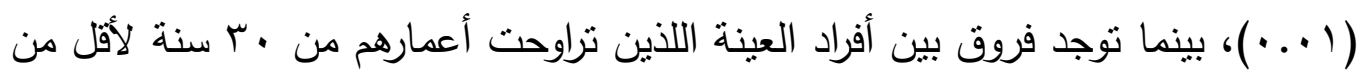

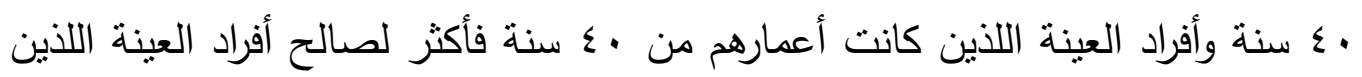

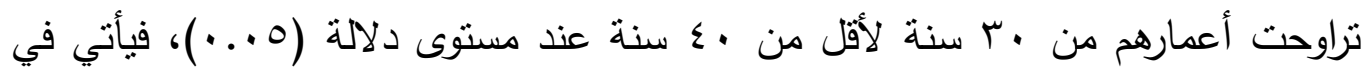

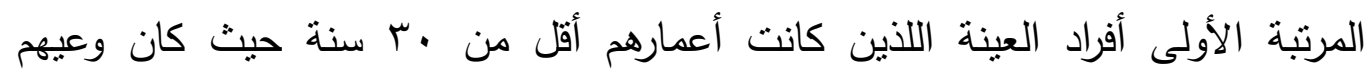

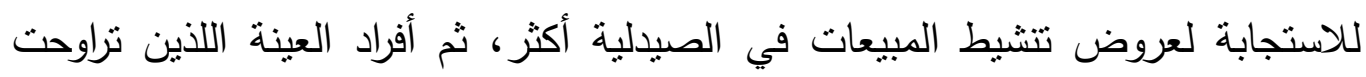

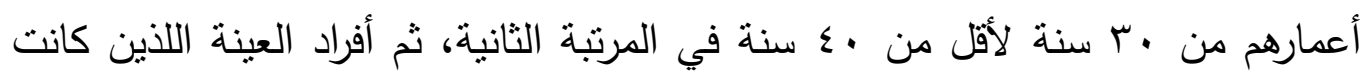


الجمعية المصرية للقراعة والمعرفة عضو الجمعية الدولية للمعرفة ILA أعمارهم من •؛ سنة فأكثر في المرتبة الأخيرة. جدول (ه 1) تحليل التباين لارجات أفراد العينة في وعيهم للاستجابة لعروض تنثيط المبيعات في

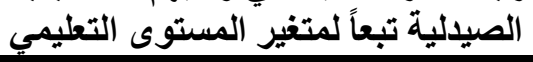

\begin{tabular}{|c|c|c|c|c|c|}
\hline الدلالة & قيمة (ف) & الحرجية & متوسط المربعات & مجموع المربعات & المستوى التعليمي \\
\hline \multirow{3}{*}{ داز } & \multirow{2}{*}{. } & $r$ & $r \mid r 1 . r .1$ & TYYY.\&.4 & بين المجموعات \\
\hline & & r & VY..9A & $18.10 .1 \% 4$ & داخل المجموعات \\
\hline & & YrA & & YTYVV.OYq & المجموع \\
\hline
\end{tabular}

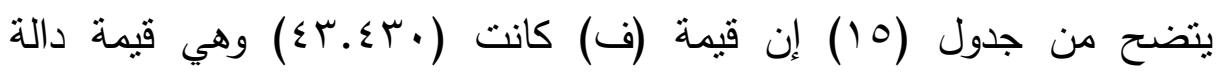

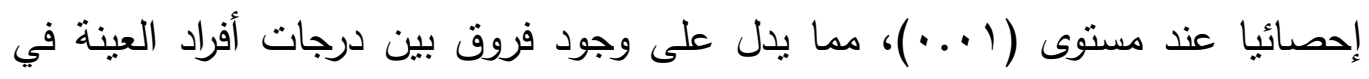

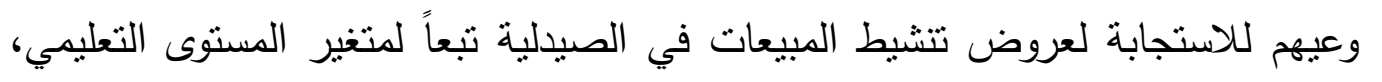

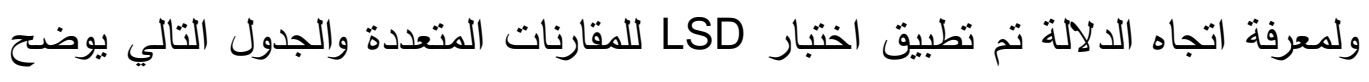
ذللك:

جدول (7 ا ) ) اختبار LSD للمقارنات المتعددة

\begin{tabular}{|c|c|c|c|}
\hline 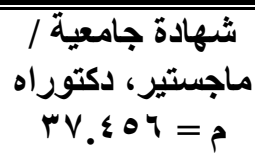 & ش = شهادة ثانوية & شهادة متثوسطة & المستوى التعليمي \\
\hline & & - & شهـادة متوسطة فأقّل \\
\hline & - & $* * V, V, Y$ & شهادة ثانوية / دبلوم \\
\hline- & $* * 11 . r \mid \varepsilon$ & $* * 19 . \cdot Y \cdot$ & شهادة جامعية / ماجستير، دكتوراه \\
\hline
\end{tabular}

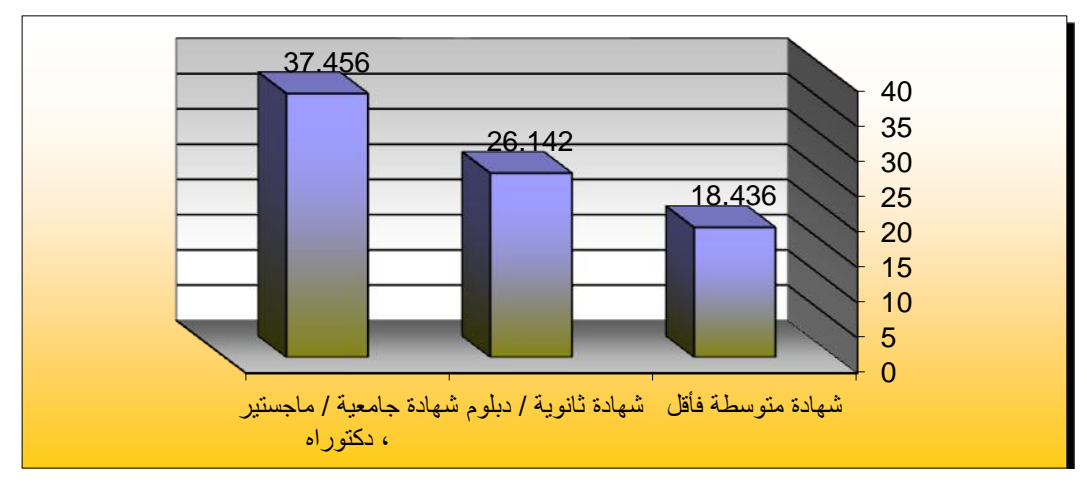


شكل ( • 1) فروق درجات أفراد العينة في وعيهم للاستجابة لعروض تتشيط المبيعات في الصيلية تبعاً لمتنير المستوى التطليمي ليروض

يتضح من جدول (7 (1) وشكل (• (1) وجود فروق في الوعي للاستجابة لعروض

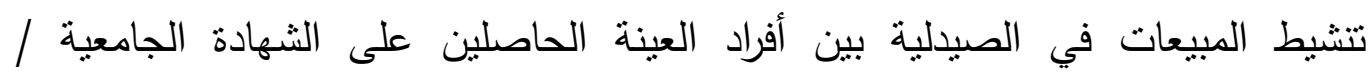

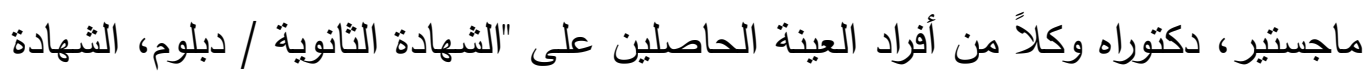

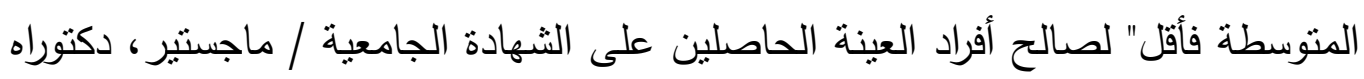

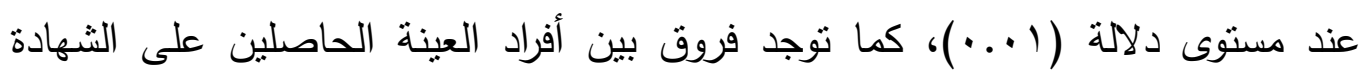

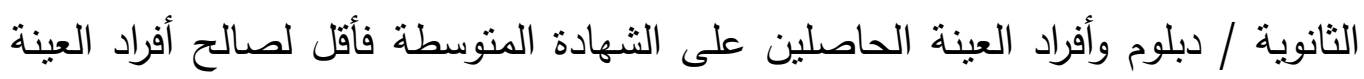

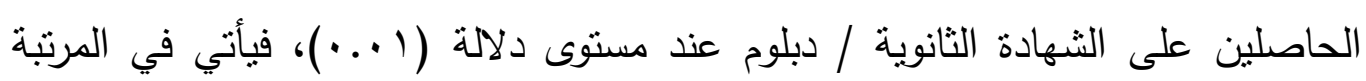

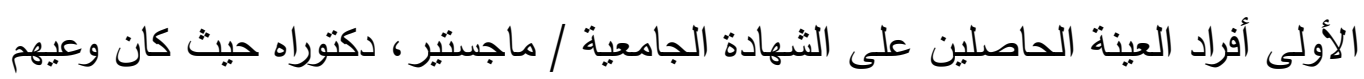

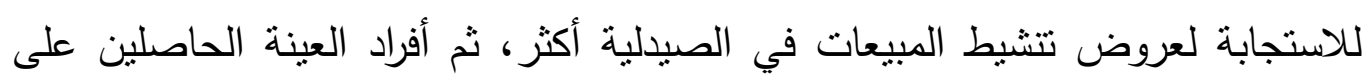

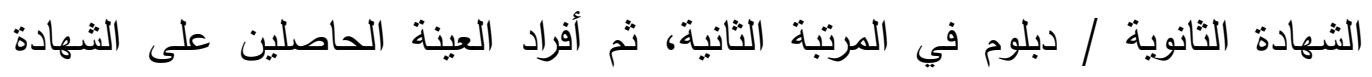
المتوسطة فأقل في المرتبة الأخيرة.

جدول (IV) الفروق في متوسط درجات أفراد العينة في وعيهم للاستجابة لعروض تتشيط المبيعات في الصيلية تبعاً لمتفير المهنة

\begin{tabular}{|c|c|c|c|c|c|c|}
\hline الدلالة & قيمة (ت) & الحرجية & العينة & الالتحراف & الحسابي & المهنة \\
\hline \multirow{2}{*}{ لدال عند الْملين } & \multirow{2}{*}{ IY.r7q } & \multirow{2}{*}{ rTV } & 147 & T. $\leqslant 7$. & $r q .1 \vee r$ & يعمل \\
\hline & & & $1 . r$ & $Y . v \diamond q$ & $r \leqslant . Y \cdot V$ & لا يعمل \\
\hline
\end{tabular}

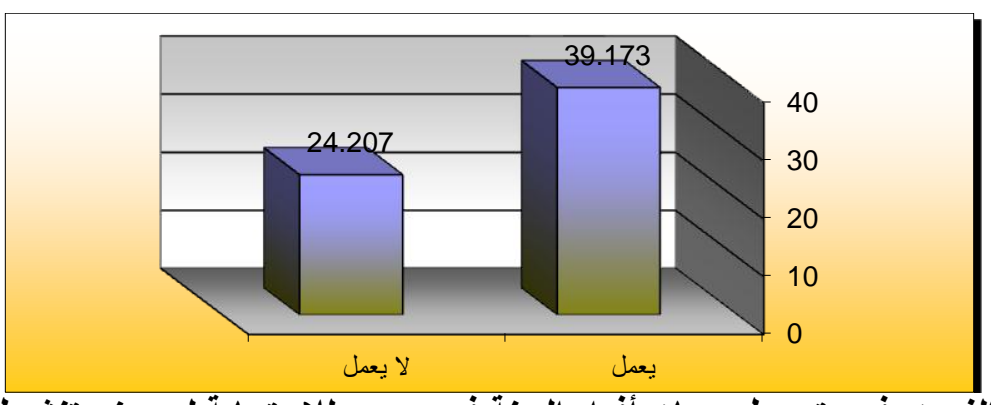

شكل ( 1 1) الفروق في متوسط درجات أفراد العينة في وعيهم للاستجابة لعروض تنثيط المبيعات في

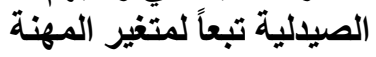




\section{الجمعية المصرية للقراءة والمعرفة عضو الجمعية الدولية للمعرفة ILA}

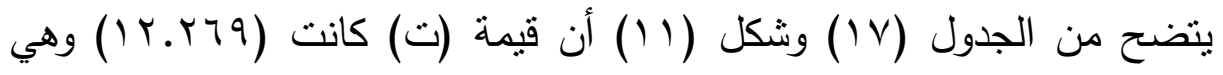

قيمة دالة إحصائيا عند مسنوى دلالة (1 . . ) لصالح العاملين، حيث بلغ منتسط درجة

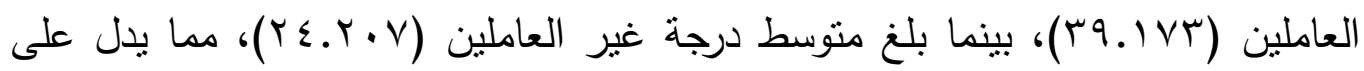
أن العاملين كان وعيهم للاستجابة لعروض تنشيط المبيعات في الصبدلية أكثر من غير

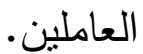

جدول (^ 1 ) تحليل التباين لارجات أفراد العينة في وعيهم للاستجابة لعروض تنشيط المبيعات في الصيلية

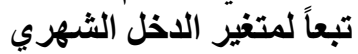

\begin{tabular}{|c|c|c|c|c|c|}
\hline الدلالة & قيمة (ف) & الرجرية & متوسط المربعات & مجموع المربعات & الاخل الشهري \\
\hline \multirow{3}{*}{ دال } & \multirow{2}{*}{$00 . r \wedge \Lambda$} & $\bar{r}$ & 1199.19. & 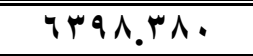 & بين المجموعات \\
\hline & & Tru & OV.VT. & & داخل المجموعات \\
\hline & & TrA & & $r \ldots r q .7 \leqslant q$ & المجموع \\
\hline
\end{tabular}

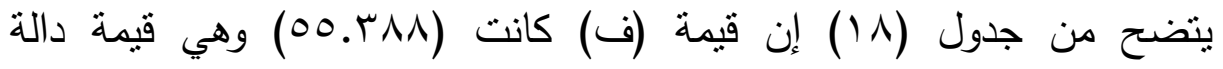
إحصائيا عند مستوى (1 (.))، مما يدل على وجود فروق بين درجات أفراد العينة في

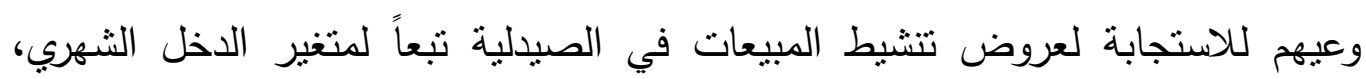
ولمعرفة اتجاه الدلالة تم تطبيق اختبار LSD للمقارنات المتعددة والجدول التالي يوضح ذلك:

جدول (9 9 ( ) اختبار LSD للمقارنات المتعددة

\begin{tabular}{|c|c|c|c|}
\hline 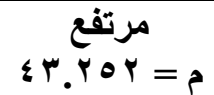 & 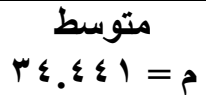 & 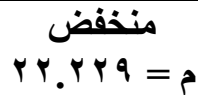 & الاخل الشهري \\
\hline & & - & منخفض \\
\hline & - & $* * I Y . Y I Y$ & متوسط \\
\hline- & $* * \wedge . \wedge 11$ & $* *{ }_{1}{ }_{1} \cdot r^{\prime}$ & مرتفع \\
\hline
\end{tabular}




\section{الجمعية المصرية للقراءة والمعرفة عضو الجمعية الدولية للمعرفة ILA}

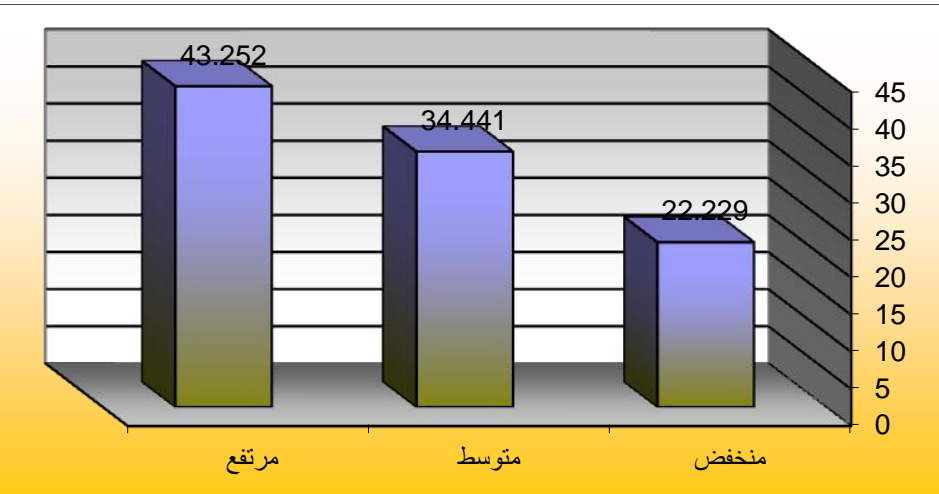

شكل (r I ) فروق درجات أفراد العينة في وعيهم للاستجابة لعروض تنشيط المبيعات في الصيدلية تبعاً

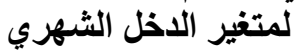

يتضح من جدول (9 ( ) وشكل (Y) ( ) وجود فروق في الوعي للاستجابة لعروض

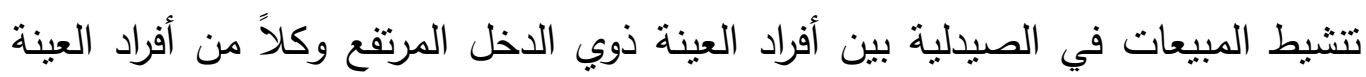

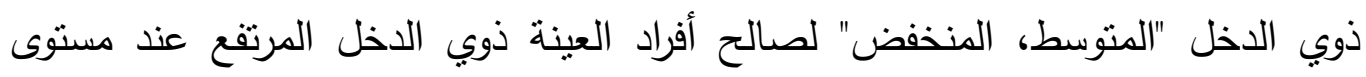

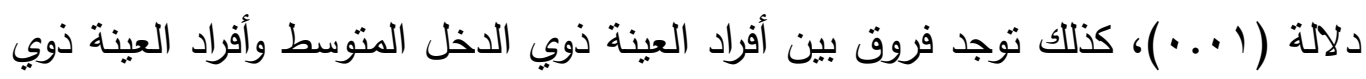

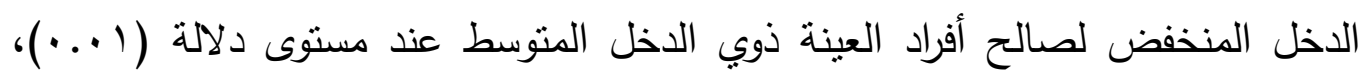

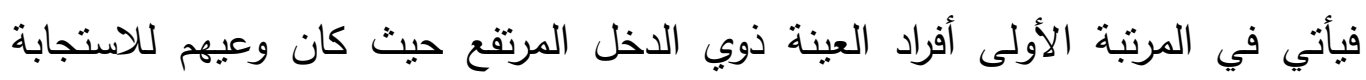

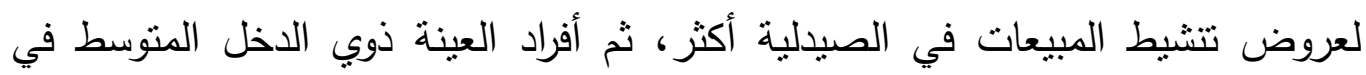

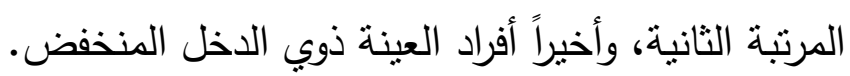
الفرض الثالث: - انه

توجد فروق ذات دلالة إحصائية بين متوسط درجات أفراد العينة في رشد قرار الثراء

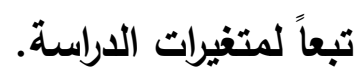

وللتحقق من هذا الفرض نم تطبيق اختبار (ت)، وحساب تحليل التباين لدرجات

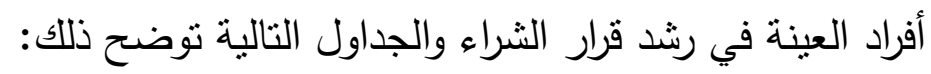

جدول (·r) الفروق في متوسط درجات أفراد العينة في رشد قرار الثراء تبعاً لمتغير الجنس

\begin{tabular}{|c|c|c|c|c|c|c|}
\hline الالالة & قيمة (ت) & الحرجية & العينة & المعياري & الحسابي & الجنس \\
\hline دال عند ا .. & 12.111 & TrV & $\mathrm{v \Lambda}$ & 0.194 & $V \leqslant .0 .0$ & ذكر \\
\hline
\end{tabular}




\section{ILA الجمعية المصرية للقراءة والمعرفة عضو الجمعية الدولية للمعرفة}

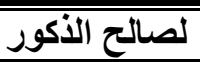 \\ 171 \\ $\varepsilon .77$ \\ Or. $\leqslant$ r.}

أنثي

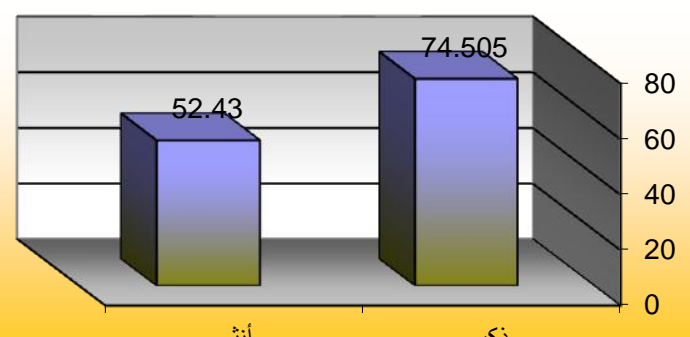

شكل (r I) الفروق في متوسط درجات أفراد العينة في رشد قرار الشراء تبعاً لمتغير الجنس

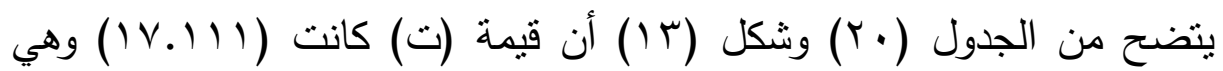

قيمة دالة إحصائيا عند مستوى دلالة (1 (...) لصالح الذكور، حيث بلغ متوسط درجة

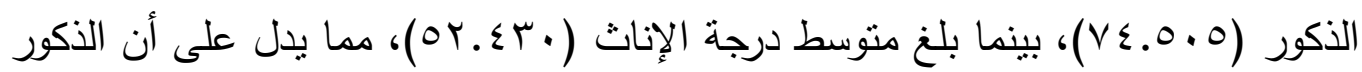

كان الرشد في قرار الثراء لديهم أكثر من الإناث.

جدول ( Y Y) تحليل التباين لارجات أفراد العينة في رشد قرار الشراء تبعاً لمتغير العمر

\begin{tabular}{|c|c|c|c|c|c|}
\hline الدلالة & قيمة (ف) & الحرية & متوسط المربعات & مجموع المربعات & العمر \\
\hline \multirow{3}{*}{ '•• } & \multirow{2}{*}{$\varepsilon q . r \leq r$} & $r$ & MITV..1s & Irrq.*q & بين المجموعات \\
\hline & & צדr & $7 \varepsilon . M 1 \leq$ & I0IVA.IMr & داخل المجموعات \\
\hline & & $r r \Lambda$ & & $r 101 Y .17 r$ & المجموع \\
\hline
\end{tabular}

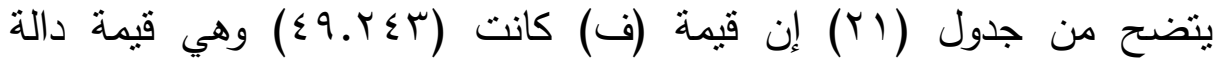

إحصائيا عند مستوى (1 . . .)، مما يدل على وجود فروق بين درجات أفراد العينة في رشد

قرار الشراء تبعاً لمتغير العمر، ولمعرفة اتجاه الدلالة تم تطبيق اختبار LSD للمقارنات المتعددة والجدول التالي يوضح ذللك:

جدول (Y Y T) اختبار LSD للمقارنات المتعددة

\begin{tabular}{|c|c|c|c|}
\hline 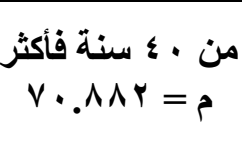 & من · من · سنة سنة لأقَّل & 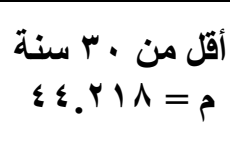 & العمر \\
\hline & & - & أقل من · ب سنة \\
\hline
\end{tabular}


الجمعية المصرية للقراعة والمعرفة عضو الجمعية الدولية للمعرفة ILA

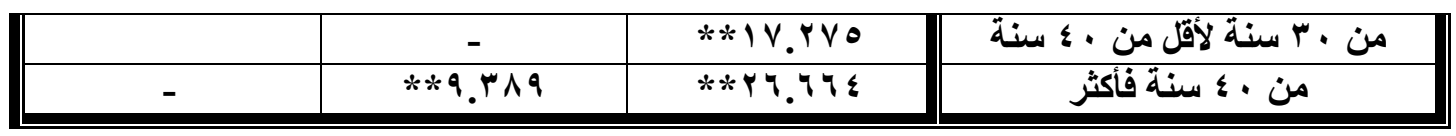

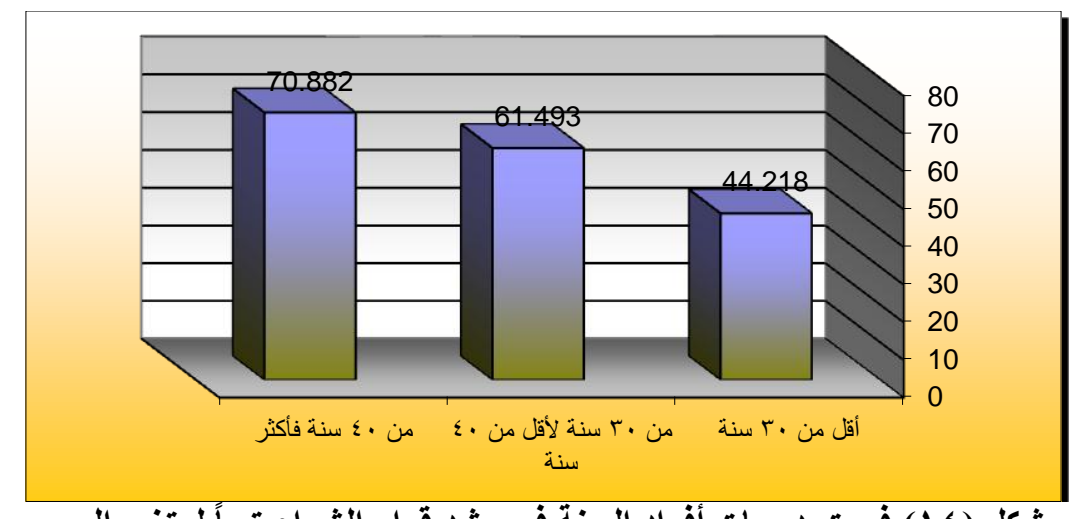

شكل (ء 1) فروق درجات أفراد العينة في رشد قرار الشراء تبعاً لمتغير العمر

يتضح من جدول (Yr) وشكل (ع ( ) وجود فروق في رشد قرار الشراء بين أفراد

العينة اللذين كانت أعمارهم من •ـ سنة فأكثر وكلاً من أفراد العينة اللذين تراوحت أعمارهم "من • ب سنة لأقل من • ع سنة، أقل من •r سنة" لصالح أفراد العينة اللذين

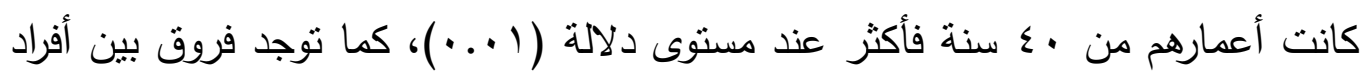
العينة اللذين تراوحت أعمارهم من ·ب سنة لأقل من • •ـ سنة وأفراد العينة اللذين كانت

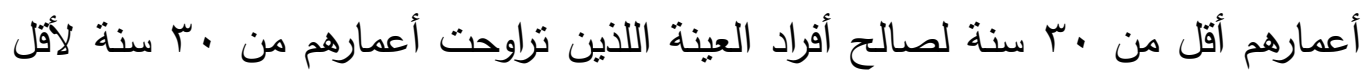

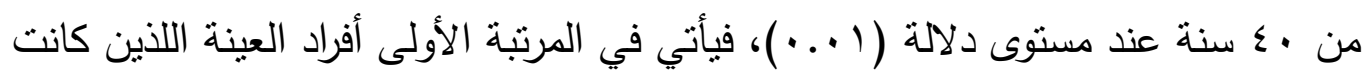
أعمارهم من · •ـ سنة فأكثر حيث كان الرشد في قرار الثراء لديهم أكثر ، ثم أفراد العينة اللذين تراوحت أعمارهم من • ب سنة لأقل من • •ـ سنة في المرتبة الثانية، ثم أفراد العينة اللذين كانت أعمارهم أقل من · r سنة في المرتبة الأخيرة.

جدول (r r ) تحليل التباين لارجات أفراد العينة في رشد قرار الشراء تبعاً لمتغير المستوى التعليمي

\begin{tabular}{|c|c|c|c|c|c|}
\hline الالالة & قيمة (ف) & الحرجات & متوسط المربعات & مجموع المربعات & المستوى التعليمي \\
\hline \multirow{3}{*}{ '•• } & \multirow{2}{*}{ r....o } & $Y$ & $r .00 .19 r$ & $711 \cdot . r \wedge \varepsilon$ & بين المجموعات \\
\hline & & rry & $q \cdot . r \vee \wedge$ & r|rrq.Y०| & داخل المجموعات \\
\hline & & $r r \Lambda$ & & $r V \varepsilon r q .7 r o$ & المجموع \\
\hline
\end{tabular}




\section{الجمعية المصرية للقراءة والمعرفة عضو الجمعية الدولية للمعرفة ILA}

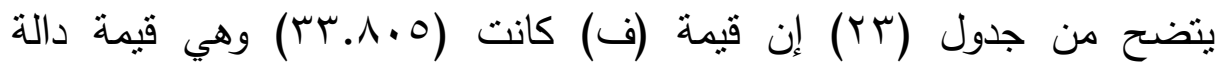

إحصائيا عند مستوى (1 (..)، مما يدل على وجود فروق بين درجات أفراد العينة في رشد

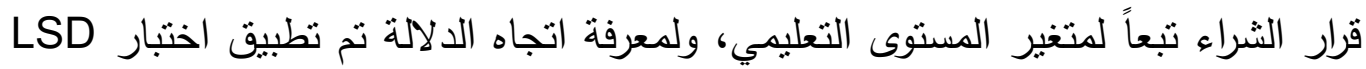
للمقارنات المتعددة والجدول التالي يوضح ذلك:

جدول (צ Y ) اختبار LSD للمقارنات المتعددة

\begin{tabular}{|c|c|c|c|}
\hline 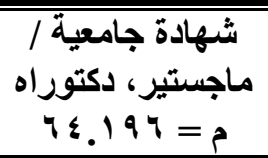 & 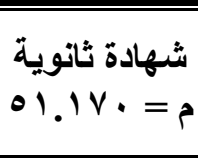 & 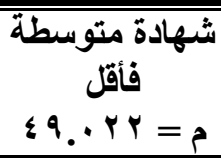 & المستوى التعليمي \\
\hline & & - & شهادة متوسطة فَأقّل \\
\hline & - & $* Y .1 \leqslant \Lambda$ & شهادة ثثانوية / دبلوم \\
\hline - & $* * 1 Y .+Y 4$ & $* * 10.1 V \varepsilon$ & شهادة جامعية / ماجستير، دكتوراه \\
\hline
\end{tabular}

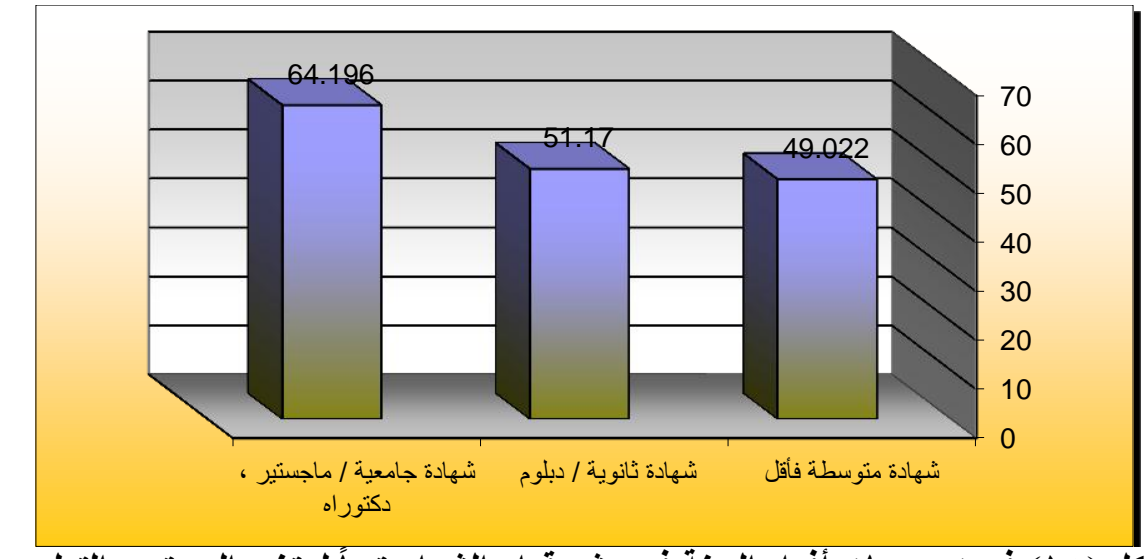

شكل (0 1) فروق درجات أفراد العينة في رشد قرار الثراء تبعاً لمتغير المستوى التطليمي

يتضح من جدول (ع) وشكل (0) وجود فروق في رشد قرار الشراء بين أفراد

العينة الحاصلين على الثهادة الجامعية / ماجستير، دكتوراه وكلاً من أفراد العينة الحاصلين على "الثهادة الثانوية / دبلوم، الثهادة المتوسطة فأقل" لصالح أفراد العينة الحاصلين على الثهادة الجامعية / ماجستير، دكتوراه عند مستوى دلالة (1 (..)، بينما

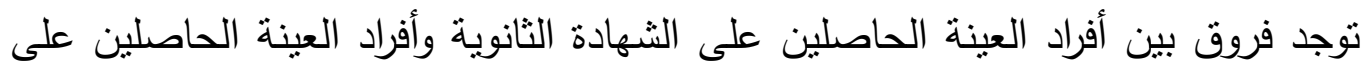

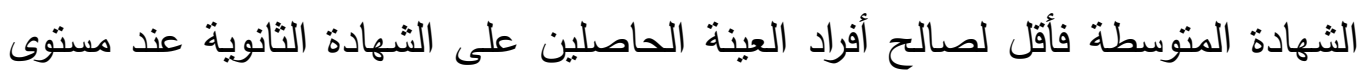


الجمعية المصرية للقراءة والمعرفة عضو الجمعية الدولية للمعرفة ILA

دلالة (0...)، فيأتي في المرتبة الأولى أفراد العينة الحاصلين على الثهادة الجامعية /

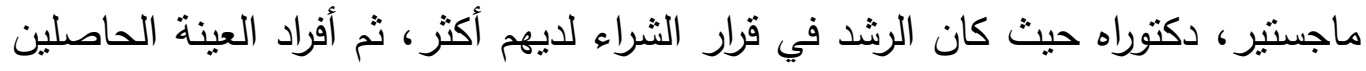

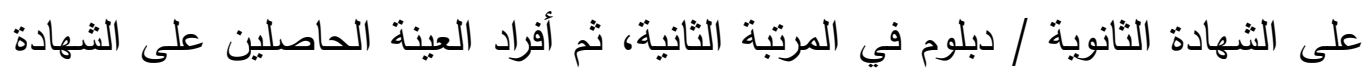
المنوسطة فأقل في المرتبة الأخيرة.

جدول (Y Y) الفروق في متوسط درجات أفراد العينة في رشد قرار الثراء تبعاً لمتغير المهنة

\begin{tabular}{|c|c|c|c|c|c|c|}
\hline الدلالة & قيمة (ت) & الحرية & العينة & الالحيرافي & الحستوسط & المهزة \\
\hline \multirow{2}{*}{ لصالح عذد العاملين } & \multirow{2}{*}{$1 \leq . \ldots$} & \multirow{2}{*}{ rrv } & 114 & $\varepsilon .90$. & 09.4 .7 & يعمل \\
\hline & & & $1 . r$ & r.Irv & $\{1 . Y \mid r$ & لا يعمل \\
\hline
\end{tabular}

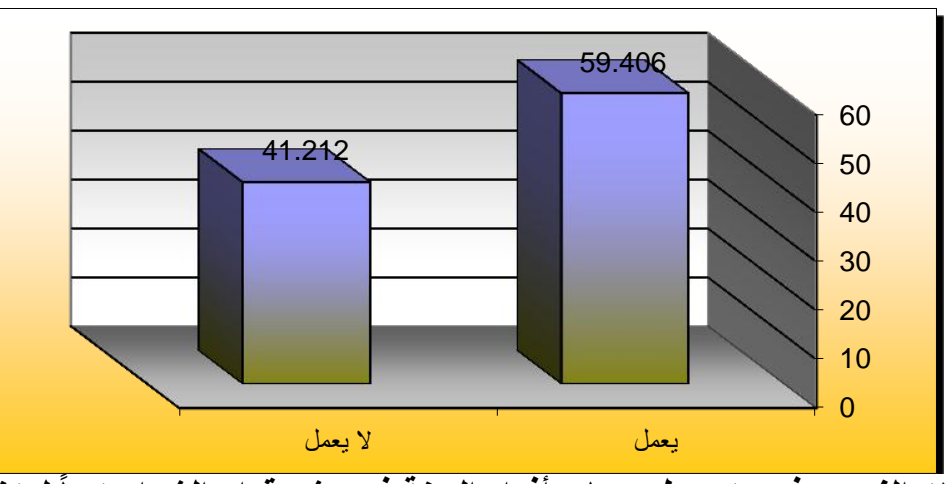

شكل (1 1) الفروق في متوسط درجات أفراد العينة في رشد قرار الثراء تبعاً لمتغير المهنة

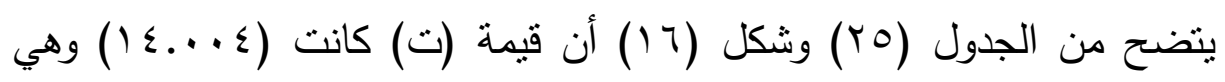

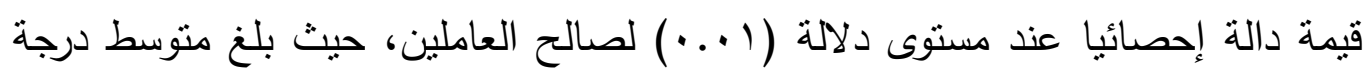

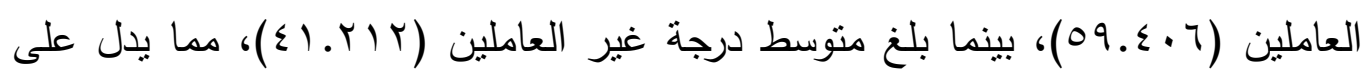

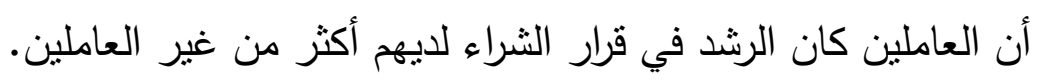

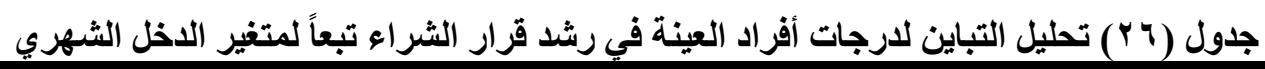

\begin{tabular}{|c|c|c|c|c|c|}
\hline الدلالة & قيمة (ف) & الحرجية & متوسط المربعات & مجموع المربعات & الاخل الشهري \\
\hline \multirow{3}{*}{ دآز } & \multirow{2}{*}{ TIVIY } & $\bar{r}$ & TYYV.TEA & $7 \leqslant 00.197$ & بين المجموعات \\
\hline & & דוזr & Or.T.Y & $1 Y T \leq T .101$ & داخل المجموعات \\
\hline & & YrA & & $\operatorname{l\wedge V} 9 \Lambda_{.} \varepsilon 0 \leqslant$ & المجموع \\
\hline
\end{tabular}




\section{الجمعية المصرية للقراعة والمعرفة عضو الجمعية الدولية للمعرفة ILA}

يتضح من جدول (Tr) إن قيمة (ف) كانت (T/VIY) وهي قيمة دالة

إحصائيا عند مستوى (1 (..)، مما يدل على وجود فروق بين درجات أفراد العينة في رشد

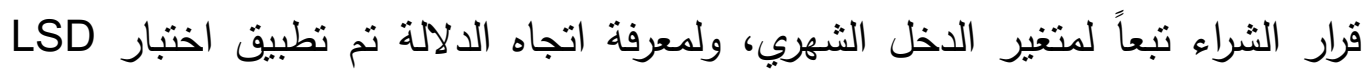
للمقارنات المتعددة والجدول التالي يوضح ذلك:

جدول (YV) اختبار LSD ) للمقارنات المتعددة

\begin{tabular}{|c|c|c|c|}
\hline م = مرتفع & م = متوسط & 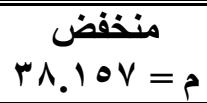 & الاخل الشهري \\
\hline & & - & منخفض \\
\hline & - & $* * 17 . \cdot V Y$ & متوسط \\
\hline- & $* * I Y .7 V Y$ & $* * Y \wedge . \vee \leq \varepsilon$ & مرتفع \\
\hline
\end{tabular}

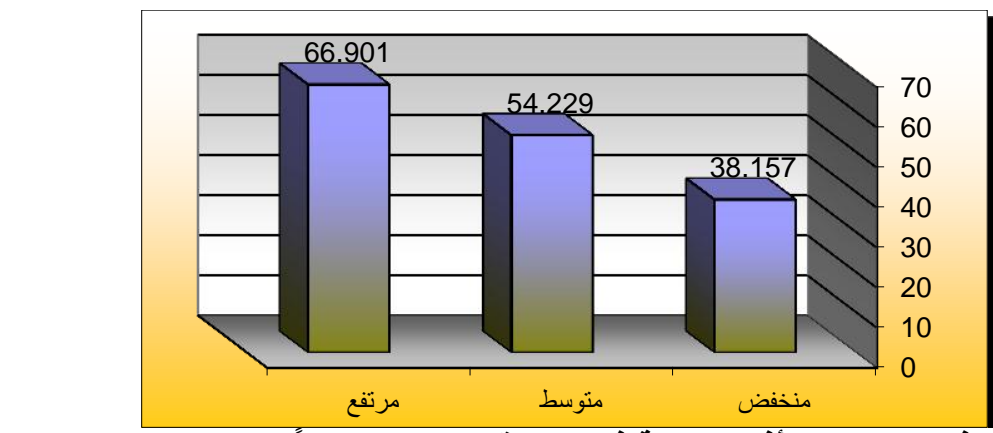

شكل (V V V Vروق درجات أفراد العينة في رشد قرار الشراء تبعاً لمتغير الدخل الثهري

بتضح من جدول (YV) وشكل (IV) وجود فروق في رشد قرار الشراء بين أفراد

العينة ذوي الدخل المرتفع وكلاً من أفراد العينة ذوي الدخل "المنوسط، المنخفض" لصالح أفراد العينة ذوي الدخل المرتفع عند مستوى دلالة ( ( ...)، كذلك توجد فروق بين أفراد

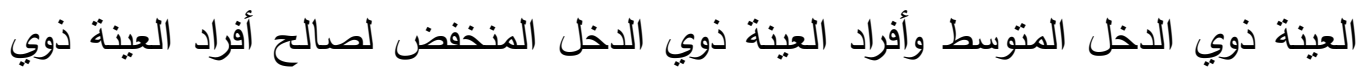
الدخل المتوسط عند مستوى دلالة ( ( ...)، فيأتي في المرنبة الأولى أفراد العينة ذوي الدخل المرتفع حيث كان الرشد في قرار الشراء لديهم أكثر، ثم أفراد العينة ذوي الدخل

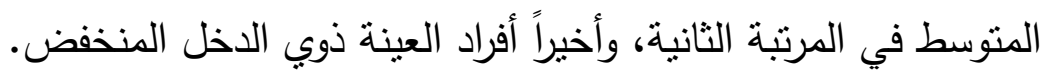

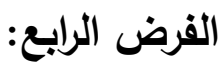


الجمعية المصرية للقراءة والمعرفة عضو الجمعية الدولية للمعرفة ILA

تختلف نسبة مشاركة العوامل المؤثرة على رشد قرار الثراء.

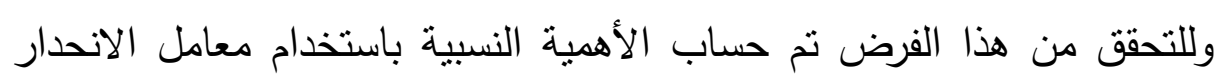

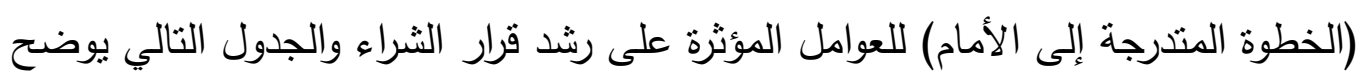

جدول (ج Y ) الأهمية النسبية باستخدام معامل الانحدار (الخطوة المتدرجة إلى الأمام) للاعوامل المؤثرة على قرام الار الثراء

\begin{tabular}{|c|c|c|c|c|c|c|c|c|}
\hline الدلالة & قيمة (ت) & الانحدار & الدلاكة & قيمة (ف) & المشاركة & الارتباط معامل & المتغير المستقل & \\
\hline$\because 1$ & 1.79. & $. r \mid r$ & $\because 1$ & $V \varepsilon .99 r$ &.$V Y \Lambda$ &.$\wedge 0 r$ & المستوى التعليمي & \\
\hline. .1 & $\Lambda . \cdot 1 \mu$ & &.$\cdot 1$ & $7 \varepsilon . Y I r$ &. .797 & . & المهنة & \\
\hline$\because 1$ & $7.21 \mathrm{~V}$ & .174 & $\because \cdot 1$ & $\leq 0.111$ &. $.71 \mathrm{~V}$ &.$\vee \wedge \neg$ & الاخل الشهري & \\
\hline$\because 1$ & $7 . \cdot \leq 0$ & $\cdot .1 \cdot r$ & $\because \cdot 1$ & M.0s. & .077 &.$V \otimes r$ & العمر & \\
\hline
\end{tabular}

يتضح من الجدول السابق إن المستوى التعليمي كان من أكثر العوامل المؤثرة

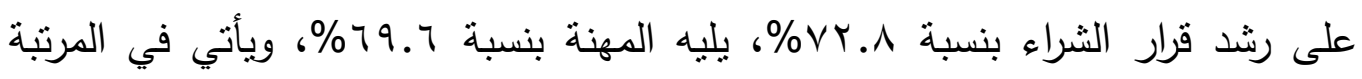

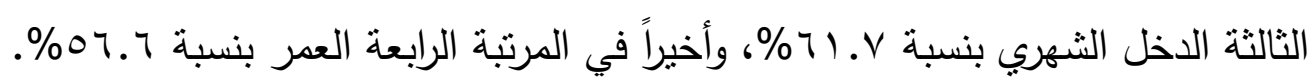

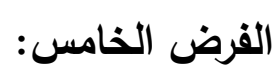

تختلف الأوزان النسبية لأولوية الاستجابة لعروض تنشيط المبيعات في الصيدلية لأفراد عينة البحث.

$$
\text { وللتحقق من هذا الفرض تم إعداد جدول الوزن النسبي التالي: }
$$

جدول ( • ب) الوزن النسبي لأولوية الاستجابة لعروض تنشيط المبيعات في الصيالية لأفراد عينة البحث

\begin{tabular}{|c|c|c|c|}
\hline الترتيب & النسبة المئوية\%\% & الوزن النسبي & الاستجابة لعروض تثشيط المبيعات في الصيّلية \\
\hline الثاني & $\%$ \%r.q & Y^ & الاستجابة لخصومات السعر \\
\hline الأول & $\%$ & $r \cdot V$ & الاستجابة لشر اء سلعة والثانية مجاناً \\
\hline الثالث & $\%$ \% . . & YOI & الاستجابة لنقاط الشراء التي يتم تجميعها \\
\hline & $\% 1 \ldots$ & $\Lambda \leq \varepsilon$ & المجموع \\
\hline
\end{tabular}




\section{الجمعية المصرية للقراءة والمعرفة عضو الجمعية الدولية للمعرفة}

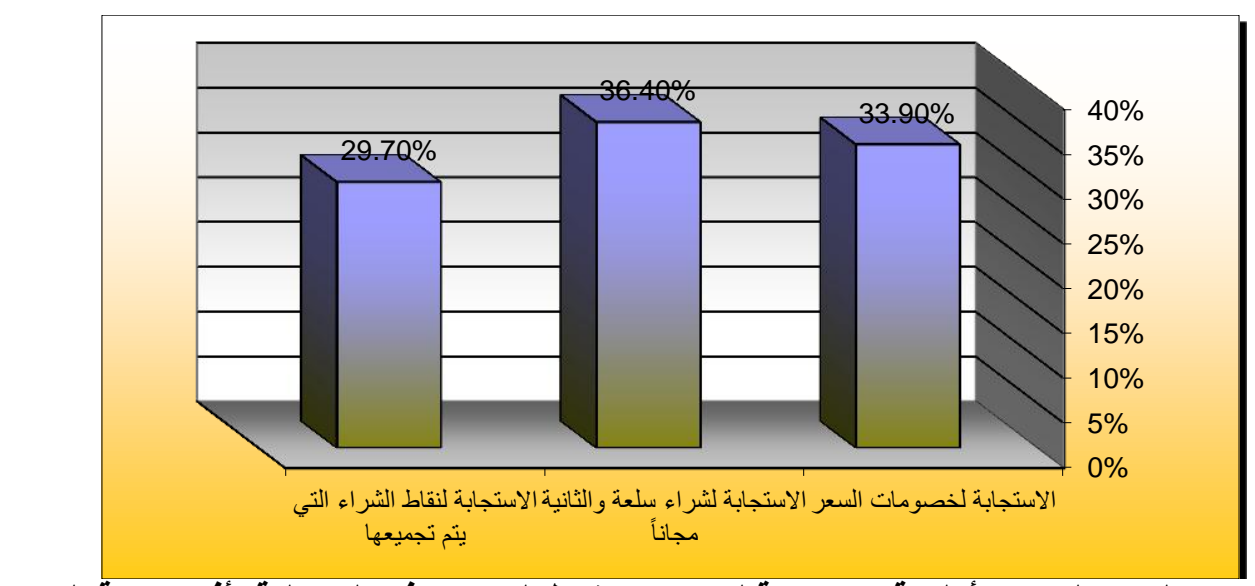

شكل (^ا) الوزن النسبي لأولوية الاستجابة لعروض تتشيط المبيعات في الصيلية لأفراد عينة البحث

يضضح من الجدول (•r) والثكل (^l) أن أولوية الاستجابة لعروض تنشيط

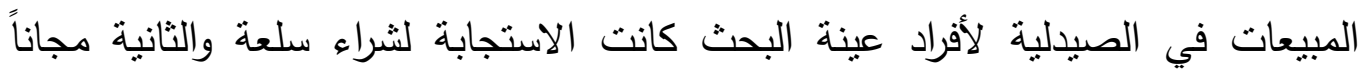

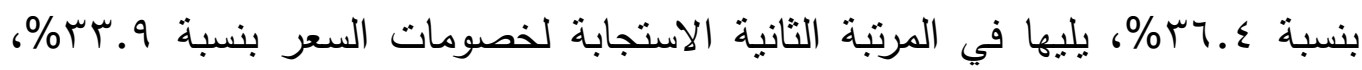

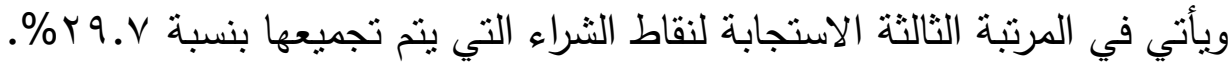
ملخص نتائج البحث:

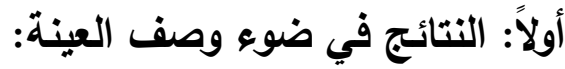

الخصائص الاجتماعية والثقافية والاقتصادية للمنسوق:

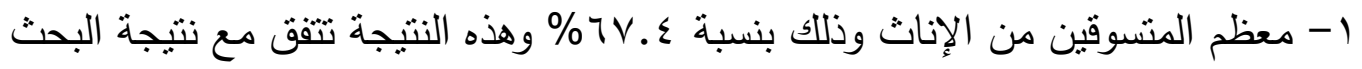

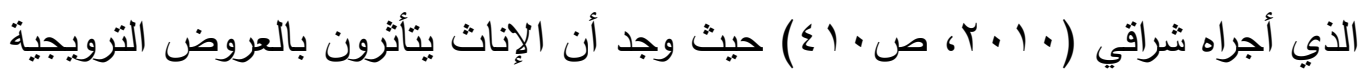

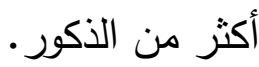

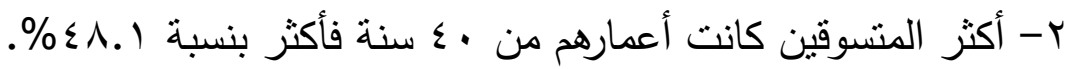
r- نصف المنسوقين كانوا حاصلين على الثهادة الجامعية / ماجستير ، دكتوراه وذلك كألك

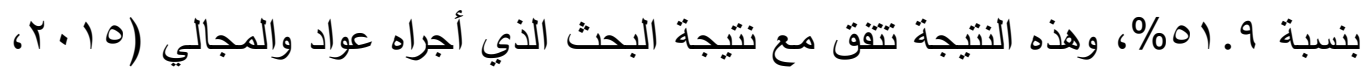

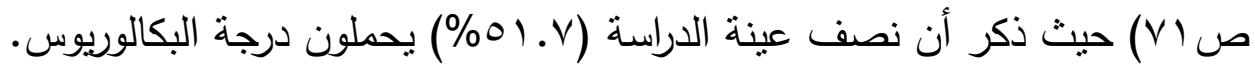




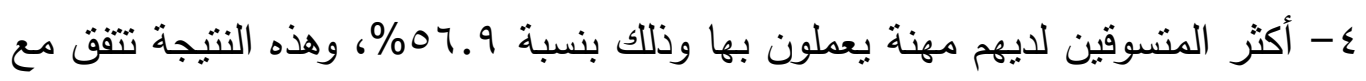

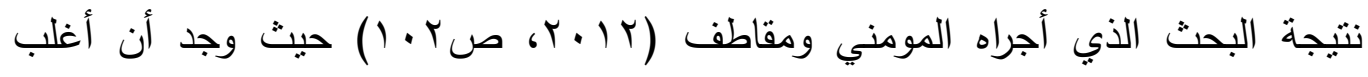
المستهلكين الذين تؤثر وسائل تتشيط المبيعات على قرارهم الثرائي من العاملين.

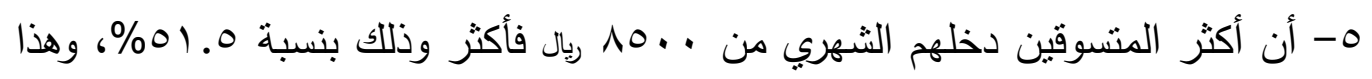

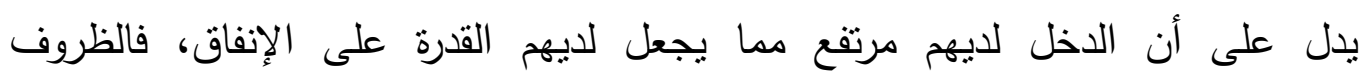

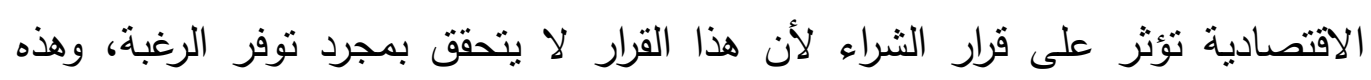

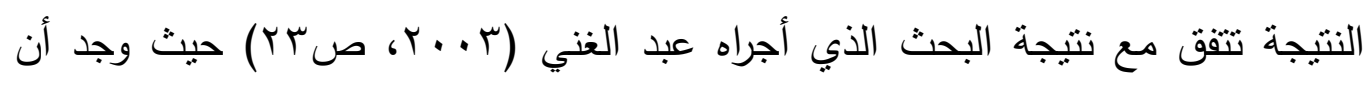

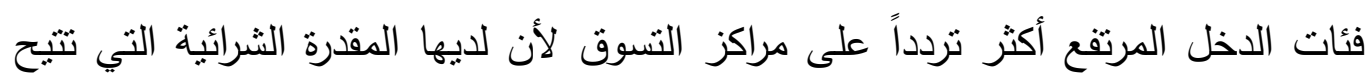

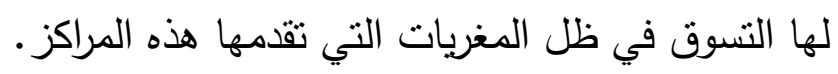
عروض تتشيط المبيعات في الصيدلية: 1- أن اكثر المتسوقين تؤثثر خصومات السعر على قرارات شرائهم للسلع من الصيدلية

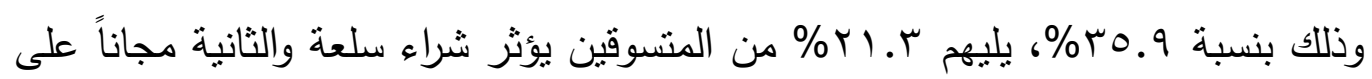

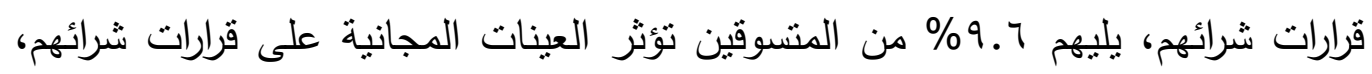

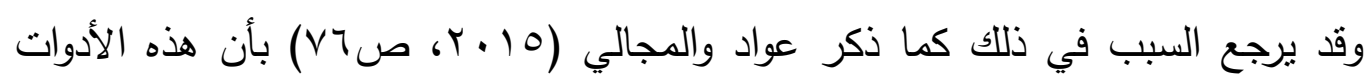

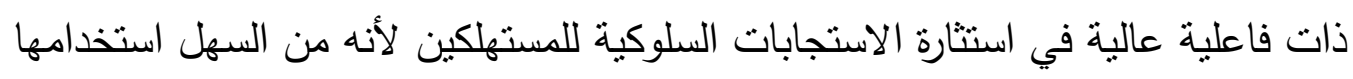

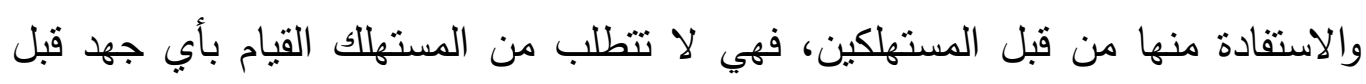

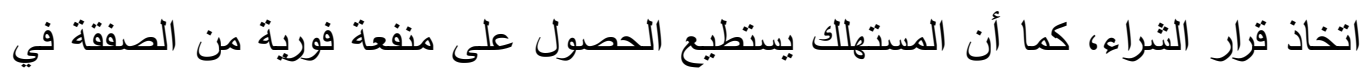

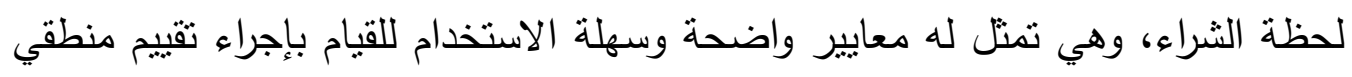
وعقلاني للعروض التي تقدمها محلات التجزئة.

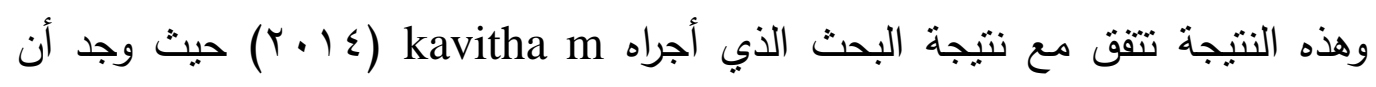
تخفيض الأسعار والحصول على منتج أضافي مجاناً أكثر أدوات تتشيط المبيعات فاعلية

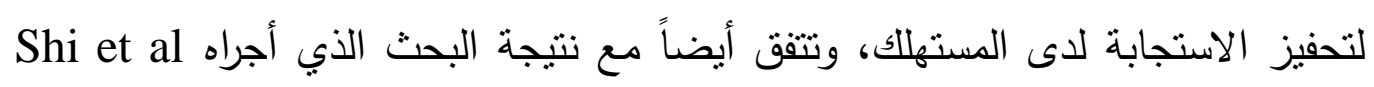

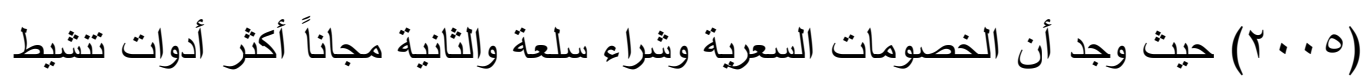
المبيعات فاعلية لنسريع الثراء والإنفاق أكثر من المخطط لهـ له. 
r- أكثر المتسوقين كانوا يشترون مستحضرات العناية والتجميل في وقت عروض تنشيط

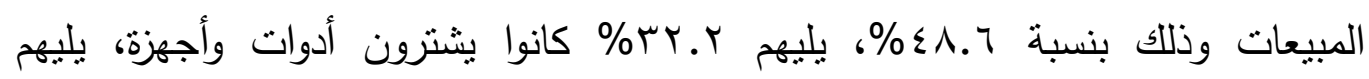

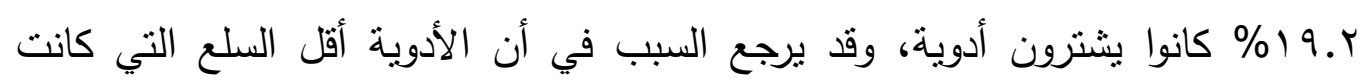

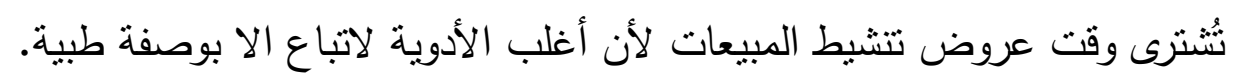

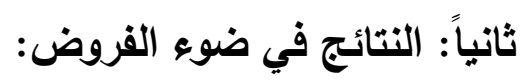
1- توجد علاقة ارتباطية طردية بين الوعي للاستجابة لعروض تنتيط المباءئ المبيعات في

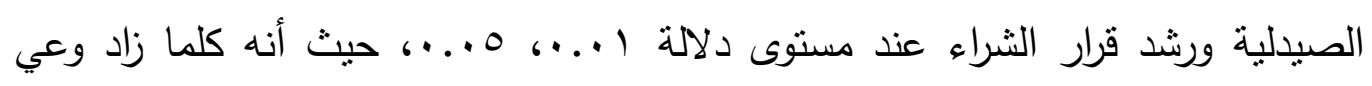

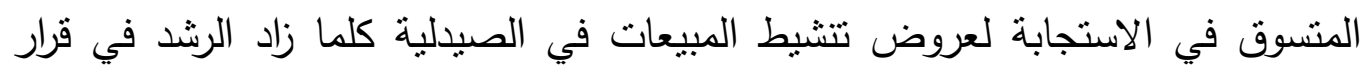

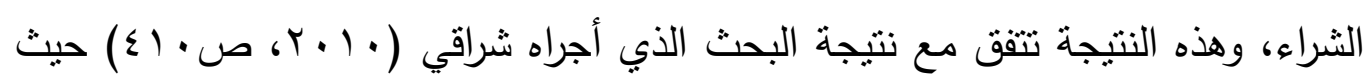

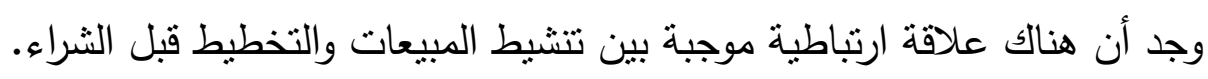

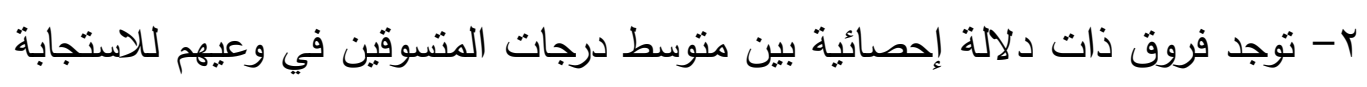

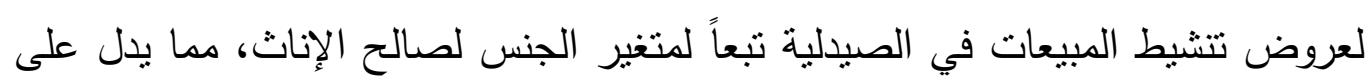
أن الإناث كان وعيهن للاستجابة لعروض تنشيط المبيعات في الصيدلية أكثر من الذكور.

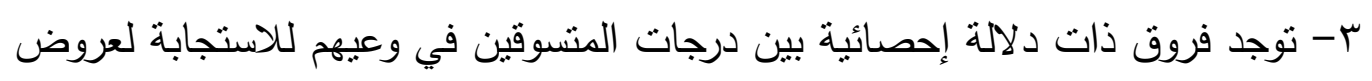

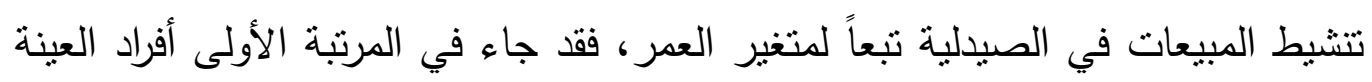

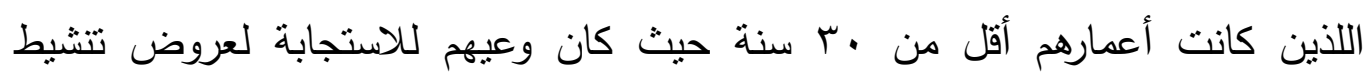

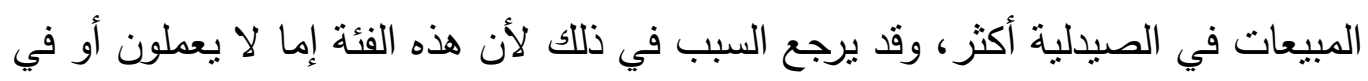

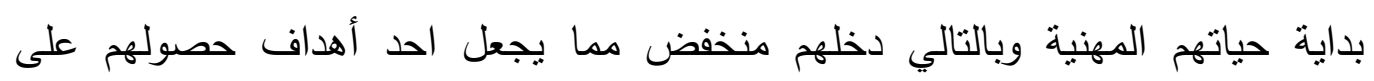
عروض تتشيط المبيعات توفير الدخل والتكيف مع الميزانية الدخططة.

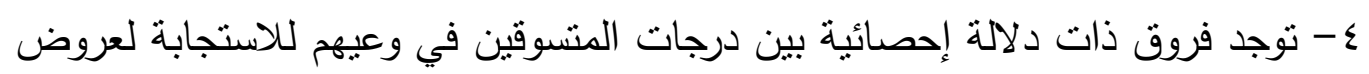

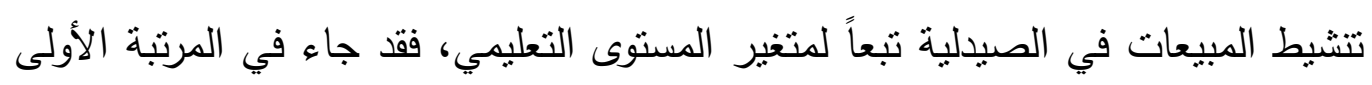

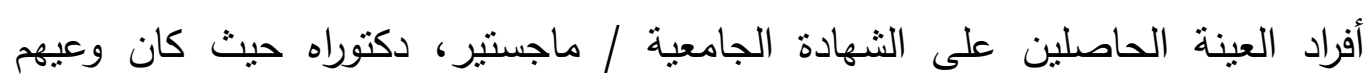

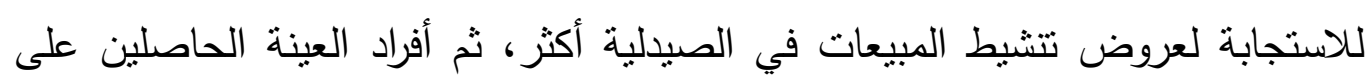


الثهادة الثانوية / دبلوم في المرتبة الثانية، ثم أفراد العينة الحاصلين على الثهادة المتوسطة فأقل في المرتبة الأخيرة. 0 - نوجد فروق ذات دلالة إحصائية بين متوسط درجات المتسوقين في وعيهم للاستجابة

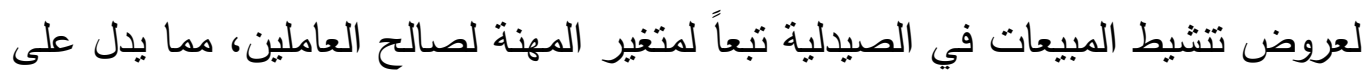

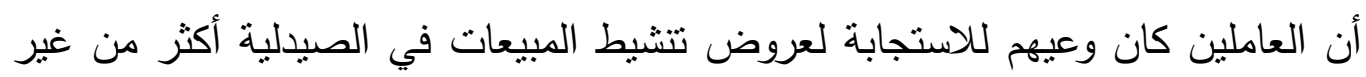

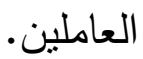
צ- نوجد فروق ذات دلالة إحصائية بين درجات المتسوقين في وعيهم للاستجابة لعروض

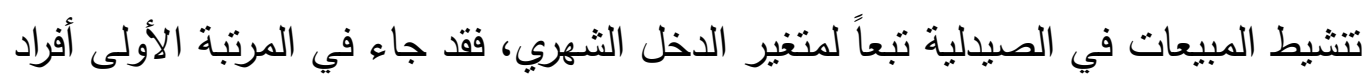

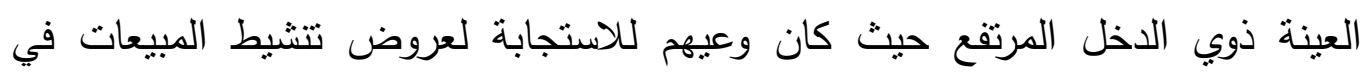

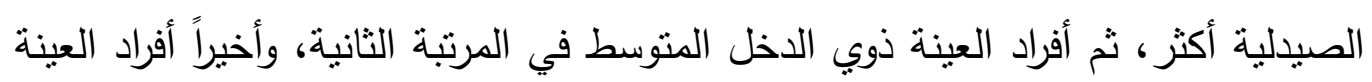

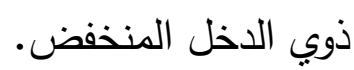
V - نوجد فروق ذات دلالة إحصائية بين متوسط درجات المتسوقين في رشد قرار الثراء

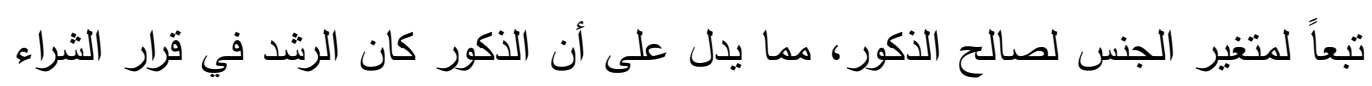

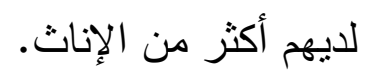
1- توجد فروق ذات دلالة إحصائية بين درجات المتسوقين في رشد قرار الثراء تبعاً

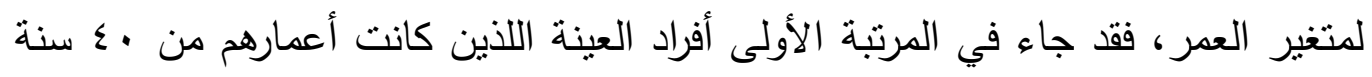

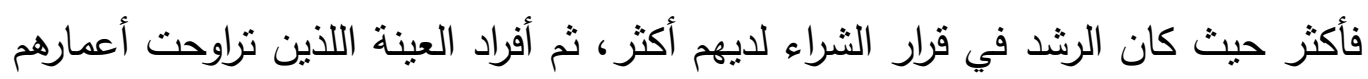

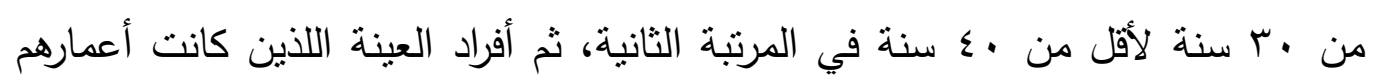
أقل من ·r أسنة في المرتبة الأخيرة. 9- توجد فروق ذات دلالة إحصائية بين درجات المتسوقين في رشد قرار الثراء تبعاً

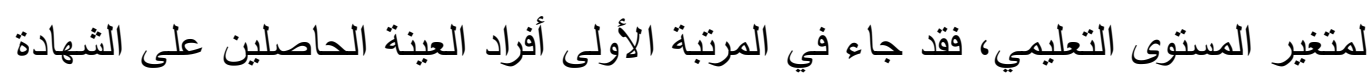

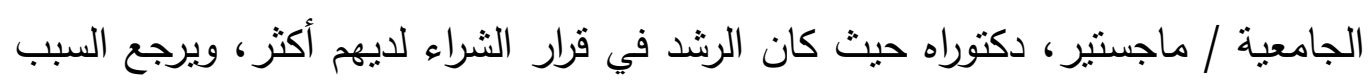

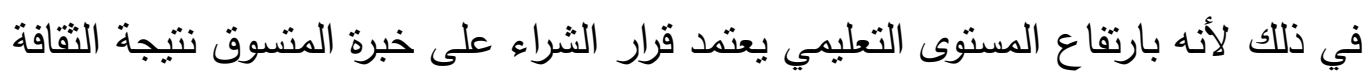
التي يتمتع بها. 
• 1 - توجد فروق ذات دلالة إحصائية بين منتسط درجات المتسوقين في رشد قرار الشراء

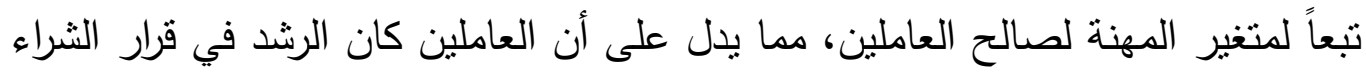
لديهم أكثر من غير العاملين. ال- توجد فروق ذات دلالة إحصائية بين درجات المتسوقين في رشد قرار الثراء تبعاً

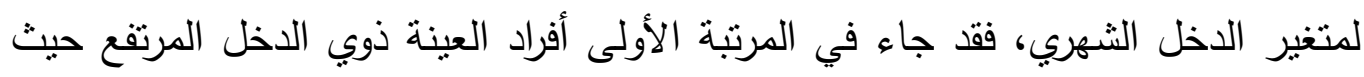
كان الرشد في قرار الثراء لديهم أكثر، ثم أفراد العينة ذوي الدخل المتوسط في المرتبة

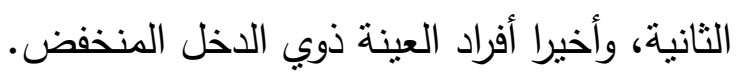
r ا - تختلف نسبة مشاركة العوامل المؤثرة على رشد قرار الثراء، حيث وجد أن المستوى

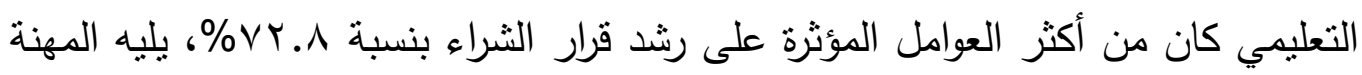

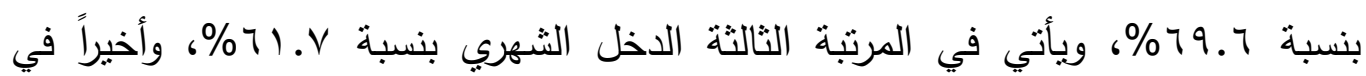
المرتبة الرابعة العمر بنسبة $7.07 \%$ با- تختلف الأوزان النسبية لأولوية الاستجابة لعروض نتشيط المبيعات في الصبدلية

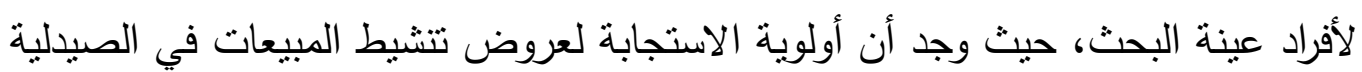
لأفراد عينة البحث كانت الاستجابة لشراء سلعة والثانية مجاناً بنسبة ع.بس\%ة، يليها في المرتبة الثانية الاستجابة لخصومات السعر بنسبة و.بr\%، ويأتي في المرتبة الثالثة الاستجابة لنقاط الشراء التي يتم تجميعها بنسبة V.9\%\%.

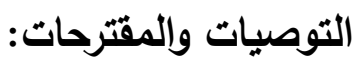
في ضوء ما أسفر عنه البحث من نتائج فإن الباحثة توصي بما يلي: ا- تصميم وإعداد وتتفيذ برامج عن طريق تكاتف كل مؤسسات المجتمع المعرفية والتعليمية والإعلامية لتتمية الوعي الاستهلاكي والانفاقي لدى المتسوق، ومحاربة الاستهلاك الزائد اثثاء شراء السلع من الصيدلية في وقت عروض تتشيط المبيعات. r- التعاون والتسيق بين الأسرة والجهات التعليمية وجمعيات حماية المستهلك ووسائل هن الإعلام في منظومة واحدة لتوعية المنسوق بمخاطر الانسياق وراء عروض تتشيط وليط المبيعات، وخلق مستهلك رشيد في مجال التسوق. 
ץ- إكساب المتسوق عن طريق التربية والتعليم كفاءة ومهارات وخبرات تساهم في خلق مستهلك رشبد في قرار الشراء ولديه الوعي في التمبيز بين حاجاته ورغباته والأهم والمهم من بينها، بحيث يضع القدرة الثرائية والحاجة إلى السلعة في أولوياته عند اتخاذ قرار شراء السلع التي عليها عروض تتشيط المبيعات، ويكون ترشيد الاستهلاك منهاجاً لحياته. ع - تفعيل دور جمعيات حماية المستهلك لحماية المستهلك من قراراته عن طريق ارشاده ونوعيته حول السلع التي يشنريها من الصيدلية في وقت عروض تتشيط المبيعات، ولحمايته من المنتجين والمسوقين الذين يقدون عروض تتشيط للمبيعات زائفة. ه- عمل ندوات لنشر ثقافة الادخار بين المتسوقين بدل ثقافة الاستهلاك بتوعية المستهلك وارشاده حول كيفية الاستجابة لعروض تتشيط المبيعات والتعامل معها حتى لا تلتهم تلك لك العروض معظم أو كل الزيادة في الدخول مما يؤثز سلباً على حجم ادخارات المستهلك. T- إيجاد وسائل لرفع مستوى الوعي الثرائي لدى المتسوق وتوجيهه باتخاذ قرار شراء

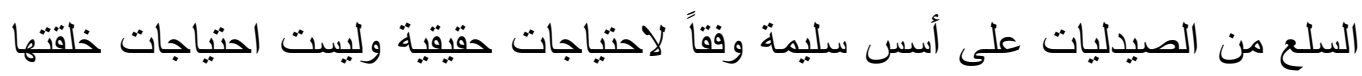
عروض تنشيط المبيعات، و إيجاد وسائل لتحسين النمط الانفاقي والاستهاكي للمنسوق. V - Vوعية الثركات المنتجة والمسوقة التي تضع عروض تنشيط للمبيعات بمسؤوليتها تجاه المتسوق اخلاقياً واجتماعياً وصحياً وهي تلك المسؤولية للتسويق بالمفهوم الحديث. 1- ممكن إجراء هذا البحث في دول عربية أخرى من أجل تعزيز النتائج التي تم التوصل باهل

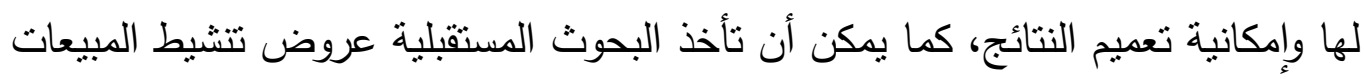
الأخرى التي لم تستخدمها الباحثة. المراجع العربية: - ماجئ ا- إبراهيم، مروة محمود (Y (Y Y) دراسة تحليلية للعوامل المؤثرة في الثراء العفوي بالتطبيق على الهاييرماركت. المجلة العلمية للاقتصاد والتجارة. مصر. العدد (1).

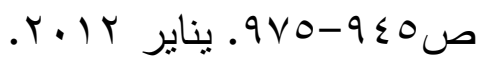


ץ- الخصاونة، عبد الهادي محمد (T . . ץ) دراسة العوامل الثخصية والاجتماعية المؤثرة على عملية اتخاذ قرار الثراء للمنتجات المختلفة في الأسر الأردنية. رسالة دكتوراه. جامعة عمان العربية للدراسات العليا. كلية الدراسات الإدارية والمالية العليا. الأردن. r- الزغيمي، مريم الزروق (Y. V P أثز الجماعات المرجعية على مراحل قرار الثراء للمستهلك النهائي: دراسة ميدانية تحليلية. مجلة الحقوق والعلوم الإنسانية. جامعة زيان

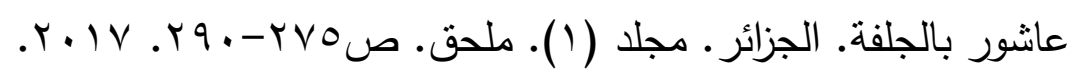

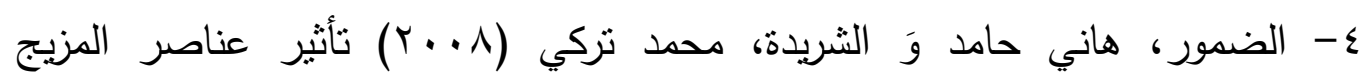
الترويجي على قرارات المستهلك الأردني في استخدام خدمة الهاتف الخلوي: دراسة

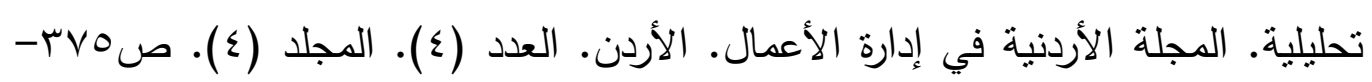
.r. . . .

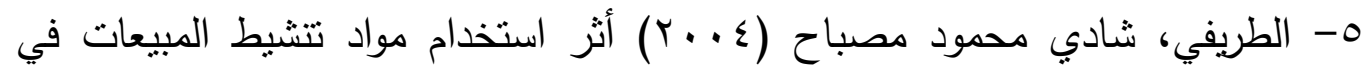
اكتساب ميزة نتافسية للشركات المنتجة والمستقيدة من الحملات الترويجية. رسالة ماجستير • جامعة آل البيت. كلية الاقتصاد والعلوم الإدارية. الأردن.

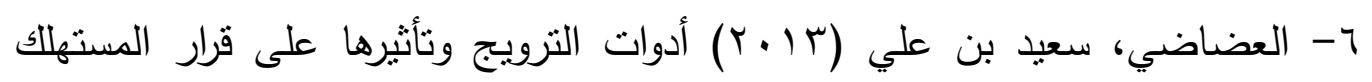
الشرائي: دراسة ميدانية. مجلة جامعة الإمام محمد بن سعود الإسلامية - العلوم الإنسانية

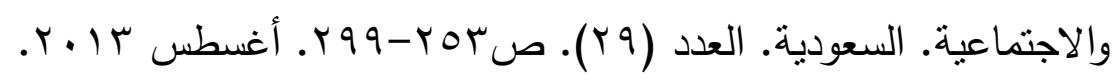

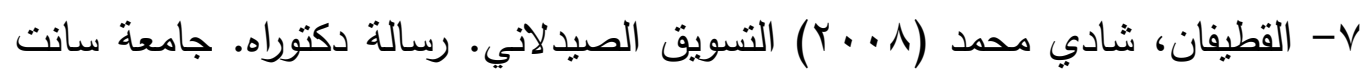

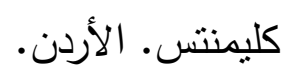

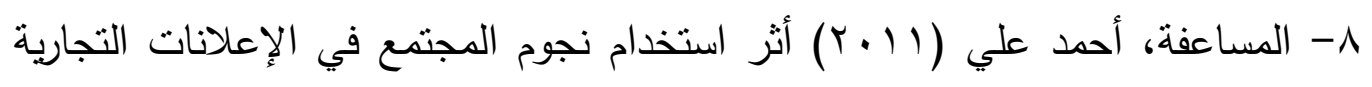
على مراحل قرار شراء مستحضرات التجميل من قبل النساء الأردنيات. رسالة ماجستير. الجامعة الأردنية. كلية الدراسات العليا. الأردن.

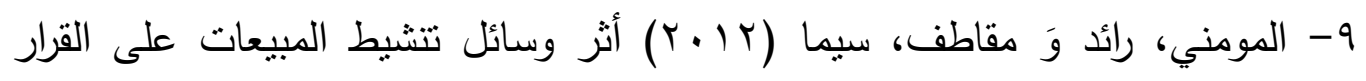
الشرائي للمستهلك الأردني - دراسة ميدانية للسلع الاستهلاكية الميسرة. مجلة العلوم

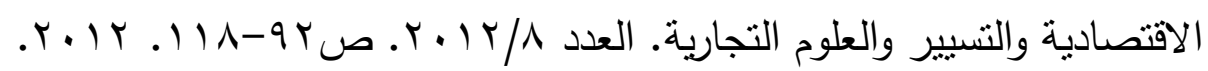




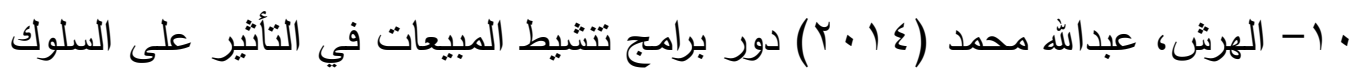
الاستهلاكي السلبي عند المستهلك الأردني. مجلة الواحات للبحوث والدراسات. المجلد

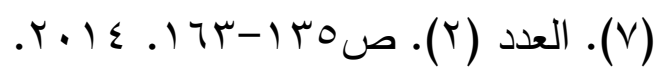

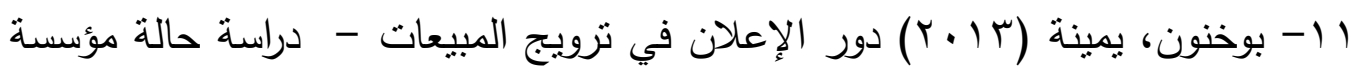

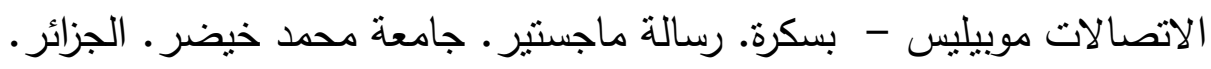

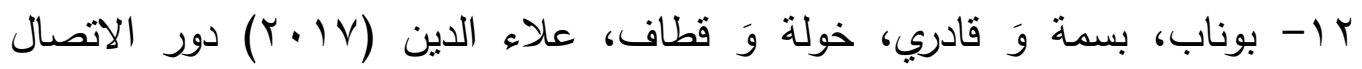
التسويقي في ضمان ولاء المستهلك - دراسة ميدانية بمؤسسة عمر بن عمر. رسالة ماجستير · جامعة ^ ماي 9 ما 1 قالمة. كلية العلوم الإنسانية والاجتماعية. الجزائر.

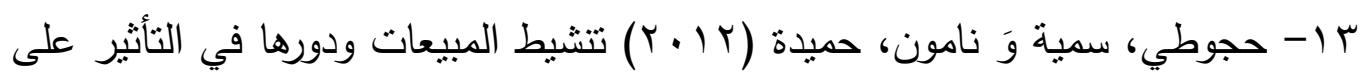
القرار الشرائي للمستهلك النهائي - دراسة حالة المؤسسة الوطنية لاتصالات الجزائر - فرع البويرة. رسالة ماجستير • جامعة أكلي محند اولحاج. معهد العلوم الاقتصادية والتجارية وعلوم التسيير • الجزائر.

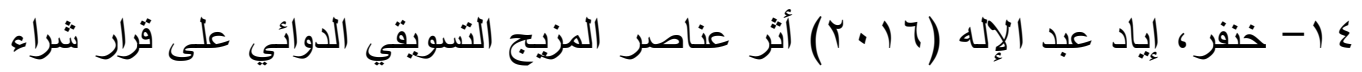
الأدوية محلية الصنع: دراسة تطبيقية في مدينة عمان. مجلة الاقتصاد والتتمية البشرية مخبر التتمية الاقتصادية والبشرية. جامعة سعد دحلب البليدة. الجزائر. العدد (ب ()).

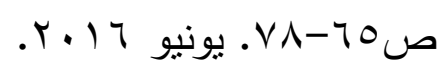

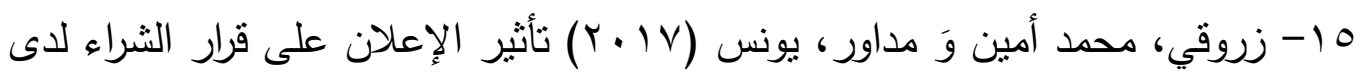
المستهلك النهائي - دراسة حالة المركز التجاري UNO عين الدلفي. رسالة ماجستير. جامعة الجيلالي بونعامة بخميس مليانة. كلية العلوم الاقتصادية والتجارية وعلوم التسيير. - الجزائر

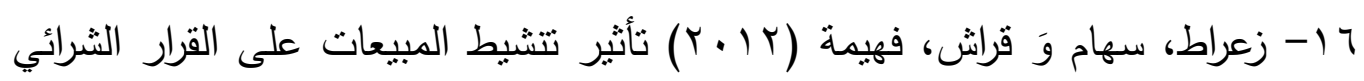
للمستهلك النهائي - دراسة ميدانية على عينة من مشتركي خدمات الهاتف النقال لأوراسكوم تيليكوم الجزائر (OTA). رسالة ماجستير • جامعة أكلي محند اولحاج. معهد

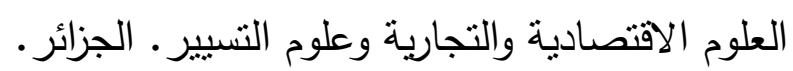




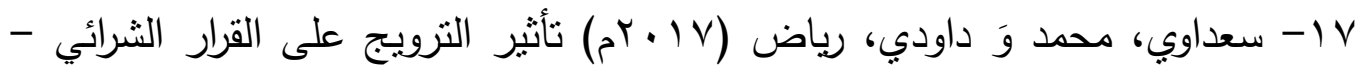
حالة ملبنة عريب. رسالة ماجستير • جامعة الجيلالي بونعامة بخميس مليانة. كلية العلوم الاقتصادية والتجارية وعلوم التسيير • الجزائر •

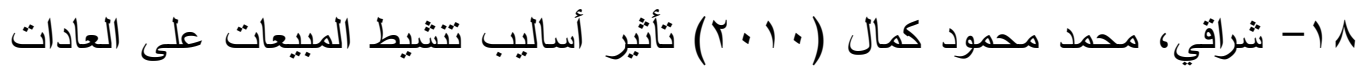
الثرائية للمستهلك بالتطبيق على الهايير ماركت. فكر وإبداع. مصر . المجلد (هوه).

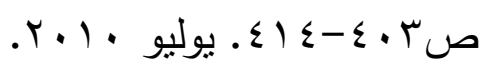
9 19- صالح، محمود عبد الحميد محمود (Y (Y) الثراء غير المخطط من مناجر التجزئة: دراسة ميدانية عن سلوكيات المستهلكين السعوديين بمدينة الرياض. مجلة الملك

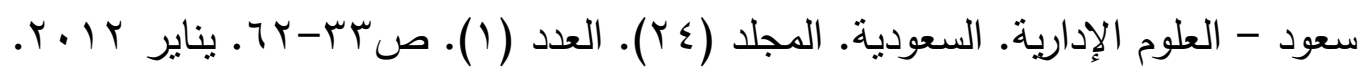

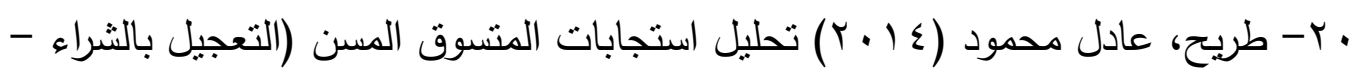
زيادة الكمية المشتراة بالمرة الواحدة) بنقطة الثراء لعروض نتشيط مبيعات السلع الغذائية بسلاسل خدمة النفس العالمية بدولة الإمارات العربية المتحدة. مجلة التجارة والتمويل. كلية

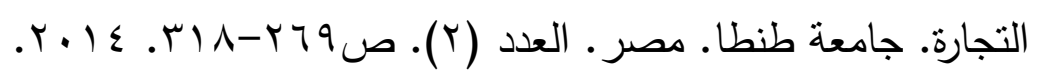

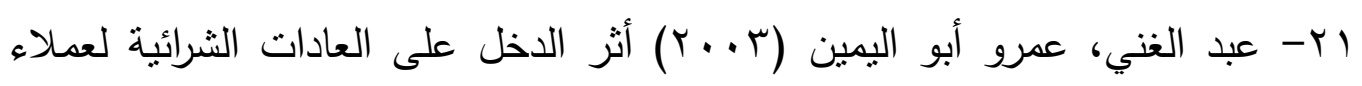

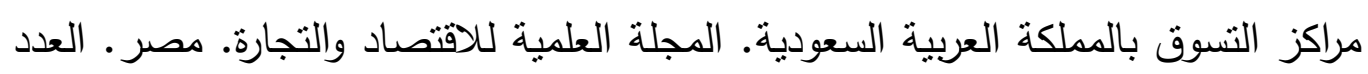

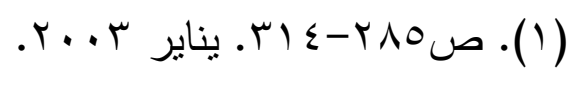

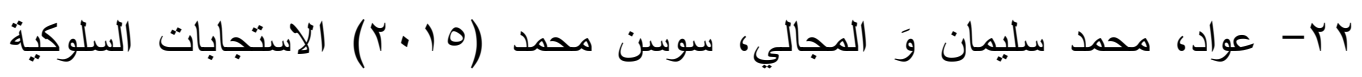
لأدوات تتشيط المبيعات من وجهة نظر المستهلك الأردني. دراسات - العلوم الإدارية.

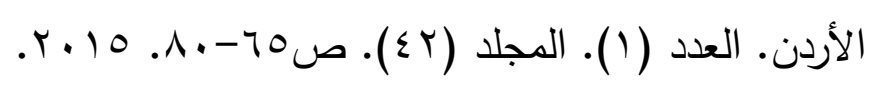

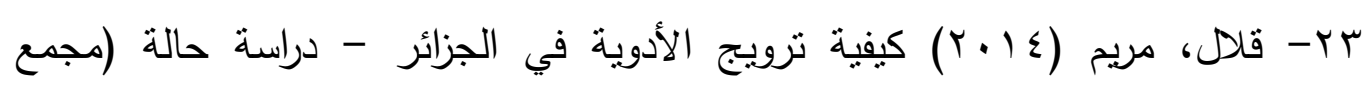
صيدال). رسالة ماجستير • جامعة أمحمد بوقرة بومرداس. كلية العلوم الاقتصادية والتجارية

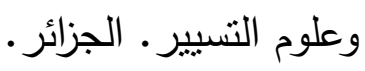




\section{ILA الجمعية المصرية للقر اءة والمعرفة عضو الجمعية الدولية للمعرفة}

ع - قواميد، بو بكر (· ( • م) فعالية البيع ودوره في خلق ميزة تتافسية - دراسة حالة مؤسسة اتصالات الجزائر • رسالة ماجستير • جامعة الجزائر ب. كلية العلوم الاقتصادية والتجارية وعلوم التسبير • الجزائر •

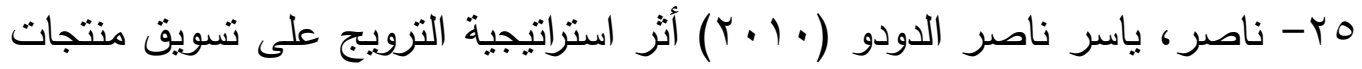

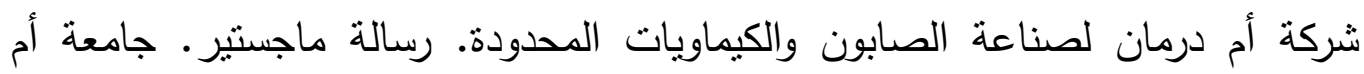
درمان الإسلامية. كلية العلوم الإدارية. السودان. جr - ناصر ، محمد وَ ماخوس، ديمة (9 . . r) دور العوامل المؤثرة في سلوك المستهلك في مجال اتخاذ القرار الثرائي. مجلة جامعة تشرين للبحوث والدراسات العلمية - سلسلة

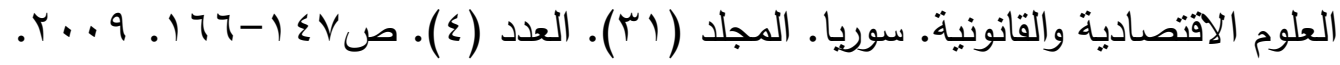

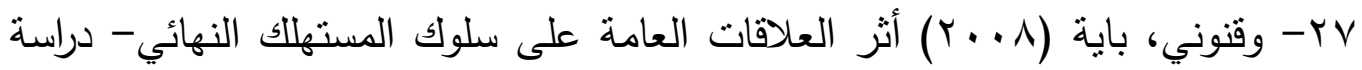
حالة شركة أوراسكوم لاتصالات الجزائر (جازي). رسالة ماجستير · جامعة أمحمد بوقره بومرداس. كلية العلوم الاقتصادية والتجارية وعلوم التسبير • الجزائر. https://www.nahdi.sa الموقع الرسمي لشركة النهدي

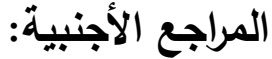

29- Alimpic, Stefan (2014) The Effectiveness of Sales Promotion Tools: Customers' Perspective. Actual Problems of Economics. 12 (162) P 142-151.

30- Aurangzeb, Mughal., Asif, Mehmood., Ammar, Mohi-ud-deen., and Bilal, Ahmad., (2014) The Impact of Promotional Tools on Consumer Buying Behavior: A Study from Pakistan. Journal of Public Administration and Governance. Vol 4. No 3. P 402-414.

31- Awunyo-Vitor, Dadson., Ayimey, Edward Kwame., and Gayibor, Regina Adzoa., (2013) Does Sales Promotion Influence Buyer Behaviour? A Study of PZ Cussons Limited. British Journal of Economics, Management \& Trade. Vol 3. No 2. P 141-152. 32- Familmaleki, Mahsa., Aghighi, Alireza., and Hamidi, Kambiz,. (2015) Analyzing the Influence of Sales Promotion on Customer 
Purchasing Behavior. International Journal of Economics \& Management Sciences. Vol 4. Issue 4.

33- Kavitha M (2014) Impact of publicity on activity responses.

Research Script International Journal of Management and Humanities. May 2014. Vol 1. Issue 1.

34- Laroche, Michel., Pons, Frank., Zgolli, Nadia., Cervellon, Marie-Cécile., and Kim, Chankon. (2003) A model of consumer response to two retail sales promotion techniques. Journal of Business Research. July 2003. Vol 56. Issue 7. p 513-522.

35- Nagar, Komal., (2009) Evaluating the Effect of Consumer Sales Promotions on Brand Loyal and Brand Switching Segments. Vision: The Journal of Business Perspective. October 1, 2009. Vol 13. Issue 4. p 35-48.

36- Obeid, Mohamad Yaman., (2014) The effect of sales promotion tools on behavioral responses. International Journal of Business and Management Invention. April 2014. Vol 3. Issue 4. P 28-31.

37- Pride, William M., and Ferrell, O.C., (2003) Marketing: concepts and strategies, U.S.A, Houghton Miffin Company.

38- Shamout, Mohamed Dawood., (2016) The Impact of Promotional Tools on Consumer Buying Behavior in Retail Market. International Journal of Business and Social Science. January 2016. Vol 7. No 1. P 75-85.

39- Shi, Yi-Zheng., Cheung, Ka-Man., \& Prendergast, Gerard., (2005) Behavioural response to sales promotion tools: A Hong Kong study. International Journal of Advertising. Vol 24. Issue 4. P 469489.

40- Soltani, Saeed., and Davanloo, Khashayar Ghajar., (2016) Understanding Sales Volume Antecedents: Measuring the Role of Consumer-oriented Selling and Sales Promotion in Iran FMCG Industry. Journal of Creating Value. November 1, 2016. Vol 2 issue 2. P 287-304. 